\title{
The Geology of Kansas ARBUCKLE GROUP
}

\author{
by \\ Evan K. Franseen, Alan P. Byrnes, Jason R. Cansler*, \\ D. Mark Steinhauff**, and Timothy R. Carr \\ Kansas Geological Survey \\ University of Kansas \\ Lawrence, KS 66047 \\ *Present Address: ChevronTexaco \\ **Present Address: ExxonMobil Exploration Company
}

\section{Introductory Comments}

\begin{abstract}
Cambrian-Ordovician Arbuckle Group rocks in Kansas occur entirely in the subsurface. As is demonstrated throughout this paper, the historical and current understanding of the Arbuckle Group rocks in Kansas has in large part been dependent on petroleumindustry philosophies, practices, and trends. The widely accepted conceptual model of Arbuckle reservoirs as an unconformity play guided drilling and completion practices in which wells were drilled into the top of the Arbuckle with relatively short penetration (under 10 to 50 $\mathrm{ft}$ ) deeper into the Arbuckle. This resulted in very little log or core data available from the Arbuckle interval. In addition, due to the early development (1917-1940) of the majority of Arbuckle reservoirs, log and geophysical data are not up to modern standards. Over the last few decades, deep penetrating wells have been drilled into the Arbuckle accompanied by full modern log suites and drill-stem tests. However, little corresponding core has been taken to calibrate the logs, and no detailed studies have been conducted to date on the more extensive, modern log data. Thus, data and detailed understanding of Arbuckle Group strata in Kansas are lacking relative to Arbuckle and ageequivalent strata from other areas in the United States, especially those where Arbuckle strata crop out. However, Arbuckle Group strata remain an important reservoir target in Kansas, and our understanding of the unit will increase with continued studies that incorporate modern data, techniques, and approaches.
\end{abstract}

\section{Historical Aspects of Arbuckle Recognition and Definition}

Strata of Late Cambrian and Early Ordovician age that lie between the Precambrian and Simpson rocks in southeastern Oklahoma were named Arbuckle limestone by J. A. Taff in 1902 from exposures in the Arbuckle Mountains (from Lee, 1956). The corresponding sequence in the Ozark region of southern Missouri was termed the "Cambro-Ordovician."

Pre-Pennsylvanian rocks were suspected to exist in the subsurface of Kansas for many years. Their eventual recognition came from wells drilled by the petroleum industry. Biostratigraphic data are lacking and, to date, no chronostratigraphic framework exists for Arbuckle Group subdivisions in Kansas. Therefore, attempts at recognition and correlation of Arbuckle Group subunits through the years relied predominantly on lithologic character and insoluble residues. As the following discussion shows, terminology for the Arbuckle Group in Kansas evolved over many decades and the term, even today, is variably used to include or exclude specific stratigraphic units.

\section{$\underline{\text { 1900-1930 }}$}

Schrader (1908) first confirmed the presence of preMississippian strata in Kansas from a well drilled near Caney, Kansas. Aurin et al. (1921) used outcrop exposures in northeastern Oklahoma to project correlations of prePennsylvanian rocks in the subsurface of the midcontinent, including Kansas, using well data. They identified a unit, which they termed "Ordovician siliceous limestone," and considered it to be Cambrian-Ordovician in age. Aurin et al. (1921) traced the siliceous limestone into Kansas as far north as Chase County. They noted that the siliceous limestone unit was a thick formation of sandy, cherty, and siliceous limestone that occurred immediately above basement rock in Kansas, except in areas of the Nemaha uplift. Aurin et al. (1921) thought that at least some of this unit was equivalent to the Arbuckle Limestone of the Arbuckle Mountains in southeastern Oklahoma.

In a study of several deep wells in Russell County, on the northern flank of the Central Kansas uplift (CKU), Twenhofel (1927) recognized green shales that contained fossils characteristic of the Decorah shale (Middle 
Ordovician) and noted several hundred feet of "crystalline limestone" beneath the green shales. Although no fossils were identified, Twenhofel (1927) suggested the limestone strata were early Ordovician or Cambrian in age. It was around this time that wildcatting activity in western-central Kansas increased, which resulted in more abundant data (McClellan, 1930).

Barwick (1928) described the stratigraphy and structure of the Salina basin in north-central Kansas. He recognized a thick pre-Pennsylvanian section in this area and divided it into seven distinct lithologic units.

Barwick's Unit 6 consists predominantly of quartz sandstone and lenses of green shale, which he identified as being equivalent to the regionally widespread St. Peter Sandstone. He suggested calling this unit St. Peter in Kansas. The recognition of the St. Peter and its unconformable relationship to the underlying Unit 7 prompted Barwick to conclude that Unit 7 could be correlated with some portion of the Arbuckle Limestone of Oklahoma. Unit 7 was described as a cherty dolomitic limestone, with a few thin streaks of rounded quartz sand, that thinned northward across the state from $900 \mathrm{ft}$ thick in southwestern Butler County to $200 \mathrm{ft}$ thick in Clay County. Barwick also advocated the retention, at least temporarily, of the term "siliceous lime" (presumably after the "siliceous limestone" of Aurin et al., 1921), due to its general usage by geologists.

Edson (1929) built upon previous work and stratigraphic subdivisions of pre-Mississippian strata by incorporating paleontologic and lithologic data from well samples in central Kansas. Her work resulted in several important contributions. Her work marked the beginning of the trend away from usage of the term "siliceous lime." In her first reference to the siliceous lime, she introduced Arbuckle limestone in parentheses and then used Arbuckle limestone in the rest of the paper. She also constructed a correlation chart for Kansas and surrounding states. In her chart, she showed the Arbuckle limestone in Kansas as being Upper Cambrian and Ordovician (Ozarkian-Canadian) in age, equivalent to the Arbuckle limestone in the Arbuckle Mountains of Oklahoma, and equivalent to the Bonneterre Dolomite through Powell Dolomite of Missouri. She also noted that Arbuckle limestone sandy lenses in Kansas generally contained less zircon and tourmaline, more barite, and many more accessory minerals than in sandy zones of dolomite above the St. Peter sand, and she suggested that those characteristics could be used to differentiate the Arbuckle limestone from other pre-Mississippian dolomites in Kansas.

McClellan (1930) constructed maps to show the subsurface distribution of pre-Mississippian strata in Kansas and Oklahoma. He noted that the Arbuckle was present throughout Kansas except in a few small areas. He postulated that the absence was due to non-deposition or to post-Arbuckle, post-Devonian, or post-Mississippian erosion. McClellan indicated that in southeastern Kansas, the Arbuckle limestone was ordinarily about 1,000 ft, on the Barton arch it was less than $300 \mathrm{ft}$, and on the Nemaha uplift (at El Dorado) it ranged from 365 to 1,100 ft thick. McClellan indicated that the Arbuckle limestone on the Barton arch was mainly white, dolomitic, and characterized by oolitic chert and interbedded coarse sandstone. He used these characteristics in comparison with a similar zone in Oklahoma to suggest that, if the units were correlative, approximately 3,400 ft of upper Arbuckle limestone was missing on the Barton arch. He also suggested that about 4,000 ft of the lower Arbuckle was missing in the area due to overlap on basement paleotopography. In southern and eastern Kansas, McClellan (1930) documented the Arbuckle as finegrained, locally cherty, brown dolomite, and speculated that it represented the middle of the formation, and thus a lower Canadian or upper Ozarkian age. He also called for the abandonment of the term "siliceous lime." He stated that the term as applied to the Arbuckle was inappropriate and could be misleading because the Arbuckle was only locally siliceous and many other formations, notably the Mississippian, were more siliceous. During the ensuing decade, the term "siliceous lime" eventually was abandoned.

\section{1-1950's -- Insoluble Residue Era in Kansas}

In 1931, McQueen published an important study in which he used detailed insoluble residue data from Cambrian-Ordovician strata in Missouri to subdivide and correlate the different units in that state. This work had a significant influence on subsequent studies and correlation of Cambrian-Ordovician strata in Kansas, especially because most samples available for study were well cuttings and were not sufficient for biostratigraphic study.

Koester (1935), in a study of the CKU, proposed that it was much more reasonable to correlate the "siliceous lime" in Kansas with the Cambrian and Ordovician section in Missouri, instead of the Arbuckle Group of Oklahoma, based on McQueen's (1931) detailed insoluble residue work in Missouri. In working with McQueen and other geologists who had examined samples from Kansas wells, Koester (1935) reported that the data confirmed the presence of the same Cambrian-Ordovician unconformities and certain units that were recognized in Missouri.

Ockerman (1935), in a study of northeastern Kansas, noted that the thick dolomitic limestone series below the St. Peter (the "siliceous lime") also was known as the Arbuckle limestone after the Arbuckle Mountains section, but he preferred using names as proposed in Missouri. He used insoluble residues from samples in Kansas to compare to insoluble residue work from McQueen's (1931) work in Missouri. The result was Okerman's 
ability to confidently correlate three zones in the "siliceous lime" with the Cotter, Roubidoux, and Bonneterre of the Missouri section. He noted that the Cotter equivalent of the "siliceous lime" is characterized by abundant chert (much of it oolitic), the Roubidoux equivalent is characterized by abundant quartz sand, and the Bonneterre equivalent is characterized by brown and green doloclastic shale. Ockerman (1935) promoted the use of insoluble residues in future work to further improve identification and correlation of pre-Pennsylvanian limestones.

Keroher (1940a, b) in a study of Linn and Montgomery counties asserted that the nearness of Arbuckle exposures in Missouri and the advanced state of classification of those rocks warranted the classification in Missouri to Kansas. These two publications were precursors to a later landmark study (Keroher and Kirby, 1948; discussed below). In his classification chart, Keroher used the Arbuckle Group to include everything from the St. Croixian (Cambrian) to Canadian (Ordovician). The Arbuckle Group was better penetrated in Linn County than in Montgomery County, and so his descriptions from there are used. He described the Lamotte Sandstone $( \pm 40 \mathrm{ft})$, unconformably overlying the Precambrian basement, as a coarse sub-round quartz sandstone, the Bonneterre Dolomite $( \pm 125 \mathrm{ft})$ as coarsely crystalline gray dolomite containing considerable fine to coarse sand, and the undifferentiated Proctor and Eminence dolomites (150 ft) as light crystalline dolomite. Keroher noted an unconformity at the top of the Cambrian section that is overlain by the Gunter Sandstone, which he described as fine to medium sand at the base. $\mathrm{He}$ described the overlying undifferentiated Gasconade and Van Buren dolomites as consisting of $135 \mathrm{ft}$ of light crystalline dolomite containing considerable chert. The Roubidoux Formation consists of $145 \mathrm{ft}$ of gray sandy dolomite and sandstone with angular to rounded sand grains and quartzose chert. The upper part of the Arbuckle Group includes undifferentiated Cotter and Jefferson City dolomites consisting of $168 \mathrm{ft}$ of tan, gray, and buff dense to crystalline dolomite, with chert and large brown oolites.

In a study of the Forest City basin in northeastern Kansas, Lee (1943) continued the use of the term Arbuckle as a convenient term to indicate undifferentiated pre-St. Peter Ordovician and Cambrian strata. He also adopted subdivisions within the Arbuckle recognized in Missouri, but excluded the Cambrian-age Bonneterre Dolomite and Lamotte Sandstone as Arbuckle equivalents. Lee (1943) thought this was a more desirable use of the Arbuckle Group name, being consistent with its usage by Ulrich (1911) in the Arbuckle Mountains.

Walters (1946) worked with Littlefield (unpublished data cited in Walters, 1946) in utilizing insoluble residues for correlation of Cambrian-Ordovician strata in Barton County on the CKU. The criteria used were 1) similarity of detailed sequences of chert types, 2) similarity of sequences of minor clastic zones as shown in insoluble residues, and 3) similarity in sequences of gross lithology factors such as dolomite crystallinity and color. Walters did not focus on detailed stratigraphic subdivision in the paper, but indicated that subdivisions and eventual confident correlation with insoluble residue work in Missouri could be made as more detailed information from wells was available outward from central Kansas towards the outcrops in Missouri.

Keroher and Kirby (1948) published a landmark report on the Upper Cambrian and Lower Ordovician rocks in Kansas. The purpose of their study was to determine the character, thickness, stratigraphic sequence, and distribution of as many zones of the Upper Cambrian and Lower Ordovician rocks in Kansas as possible. In addition to subsurface studies in Kansas, they utilized outcrops in Missouri, South Dakota, and the Front Range of the Rocky Mountains to aid in their identifications and correlations. Following along the same line as previous studies, they incorporated samples and insoluble residues from outcrops and wells drilled in Missouri to help in the identification and correlation of various stratigraphic units from Missouri into Kansas. The resultant product was lithostratigraphic correlation of larger subdivisions across the entire state. Although Keroher and Kirby (1948) advocated the use of the Missouri subdivisions for Kansas Arbuckle strata, they also recognized that the name "Arbuckle" was well established among geologists and others in the petroleum industry. Therefore, upon recommendation of oil geologists in Kansas, Keroher and Kirby (1948) retained "Arbuckle" as a group name for all Paleozoic beds older than the St. Peter Sandstone or Simpson Formation (now Simpson Group) in Kansas, and adopted subdivisions of the Missouri classification. However, they argued against the revised usage of "Arbuckle," as proposed by Lee (1943), and included all Cambrian-age rocks, including the Bonneterre Dolomite and Lamotte Sandstone, in their definition of Arbuckle.

The following is a synopsis of characteristics, descriptions, and correlations of subdivisions made by Keroher and Kirby (1948). Keroher and Kirby (1948) produced cross sections (fig. 1) showing correlations of Arbuckle units across various parts of the state, and thickness maps of the Arbuckle units (fig. 2). Keroher and Kirby (1948) give a thickness range of 1,000-1,200 ft for the Arbuckle in southeastern Kansas with a thinning northward to approximately $500 \mathrm{ft}$, near Kansas City with continued thinning across the Nebraska state line. In south-central Kansas, the Arbuckle is approximately 900 $\mathrm{ft}$ thick with an abrupt thinning to less than $300 \mathrm{ft}$ in north-central Kansas (Ottawa County). They describe an average thickness of $600 \mathrm{ft}$ for the west-central portion of the state, but note thickness varies considerably in the CKU area because of local structural conditions. Arbuckle strata are locally absent in this area. They were not able to determine Arbuckle thickness in southwestern Kansas due to lack of samples, but speculated that the Arbuckle may 
Section A-A'

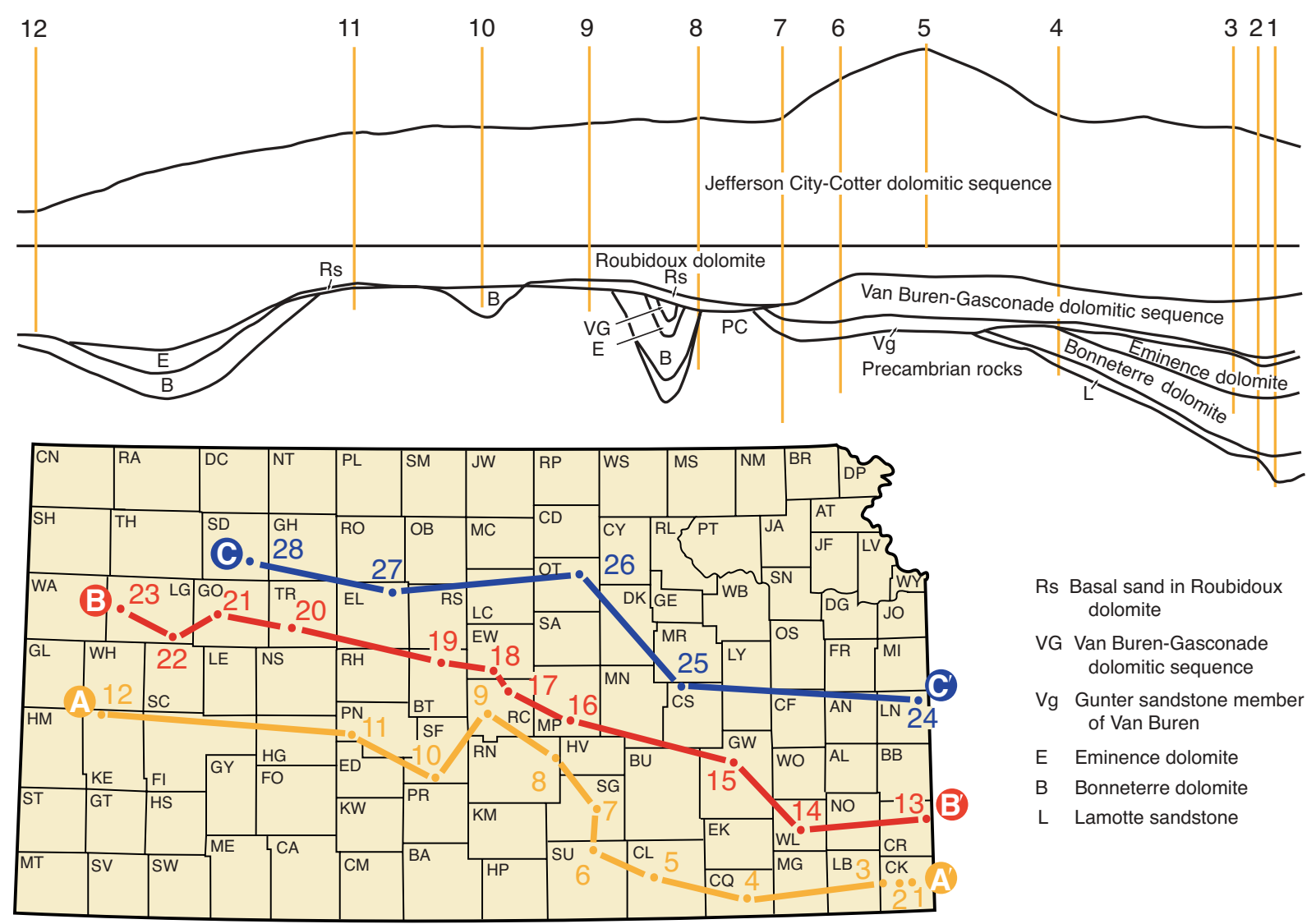

Section B-B'
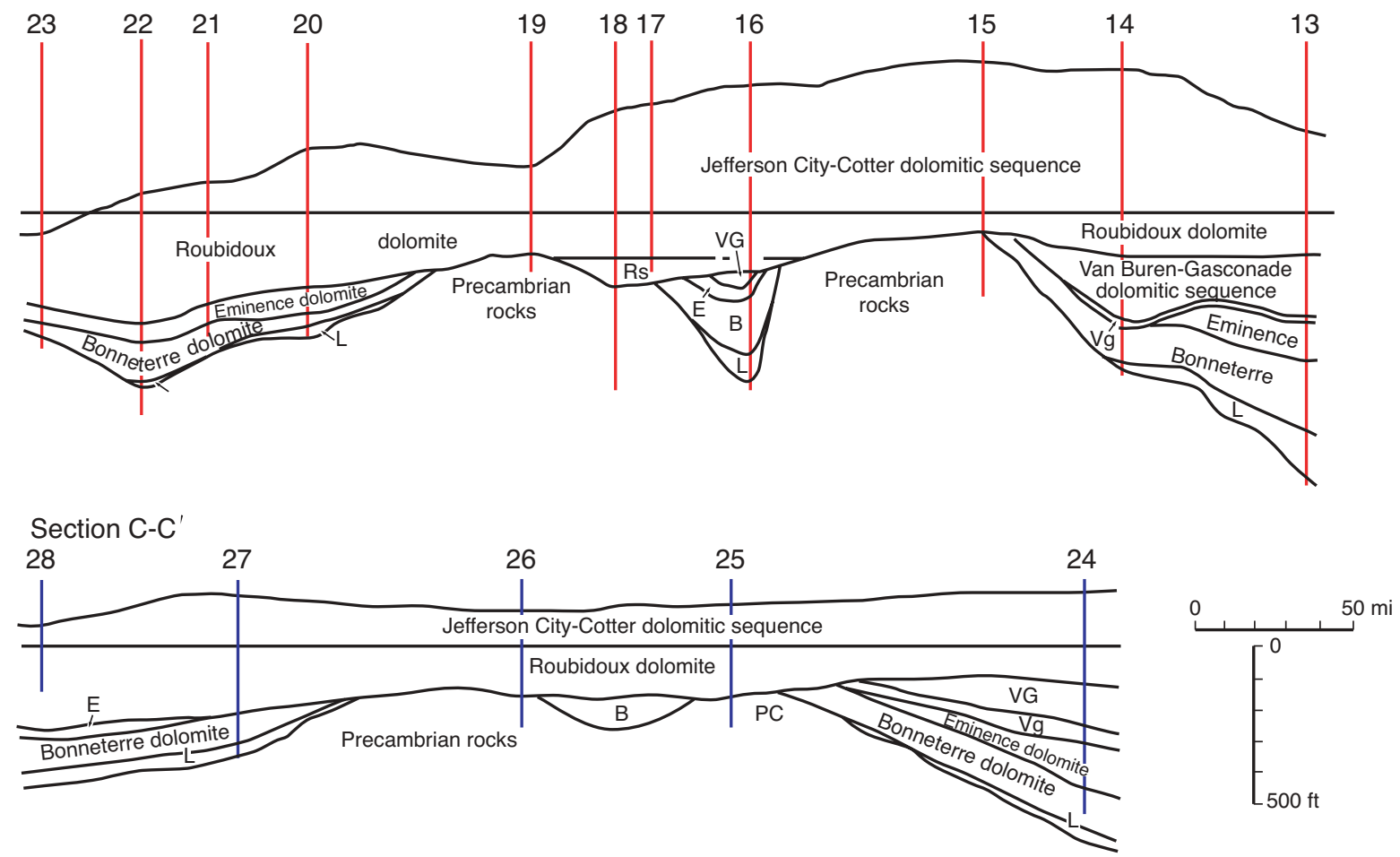

FIGURE 1 (this page and following page). Diagrammatic cross sections of Cambrian-Ordovician (Arbuckle Group) strata across Kansas. From Keroher and Kirby (1948). 
Section D-D

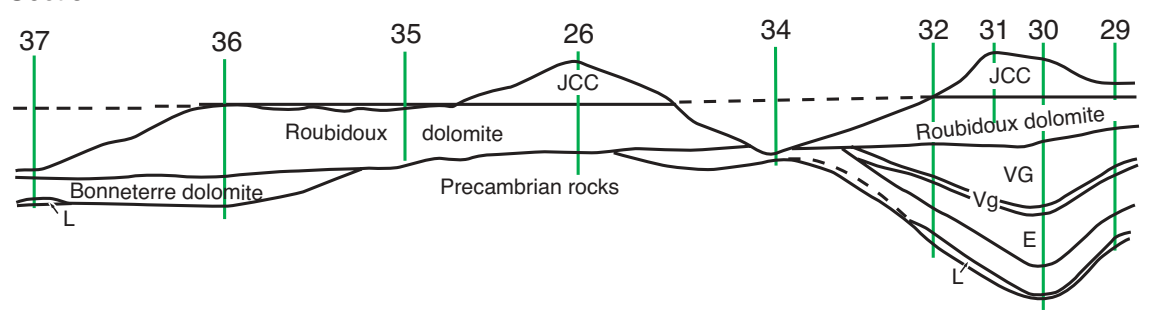

Section E-E'
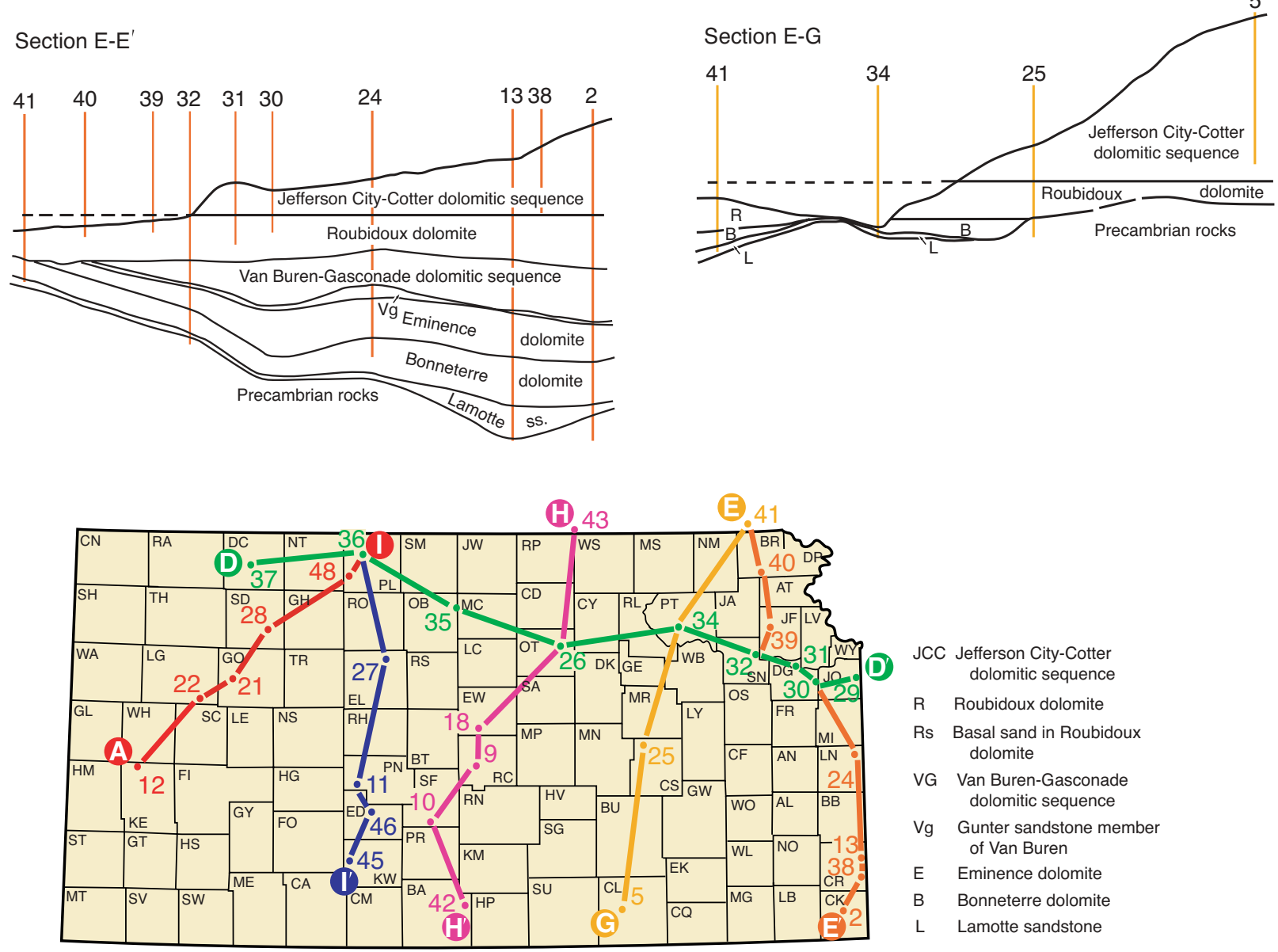

Section I-A

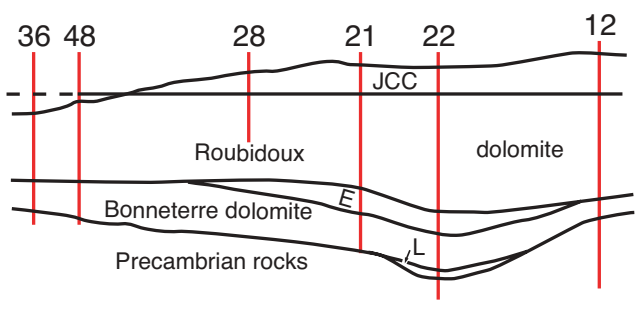

Section I-I'

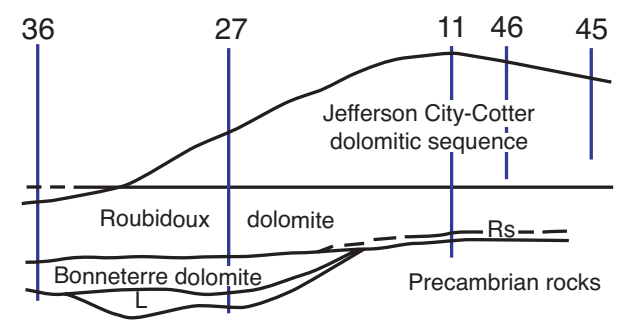

\section{Section $\mathrm{H}-\mathrm{H}^{\prime}$}

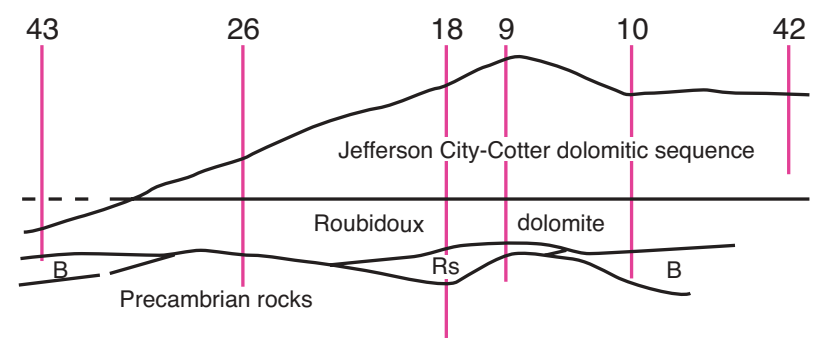




\section{A - Bonneterre dolomite}

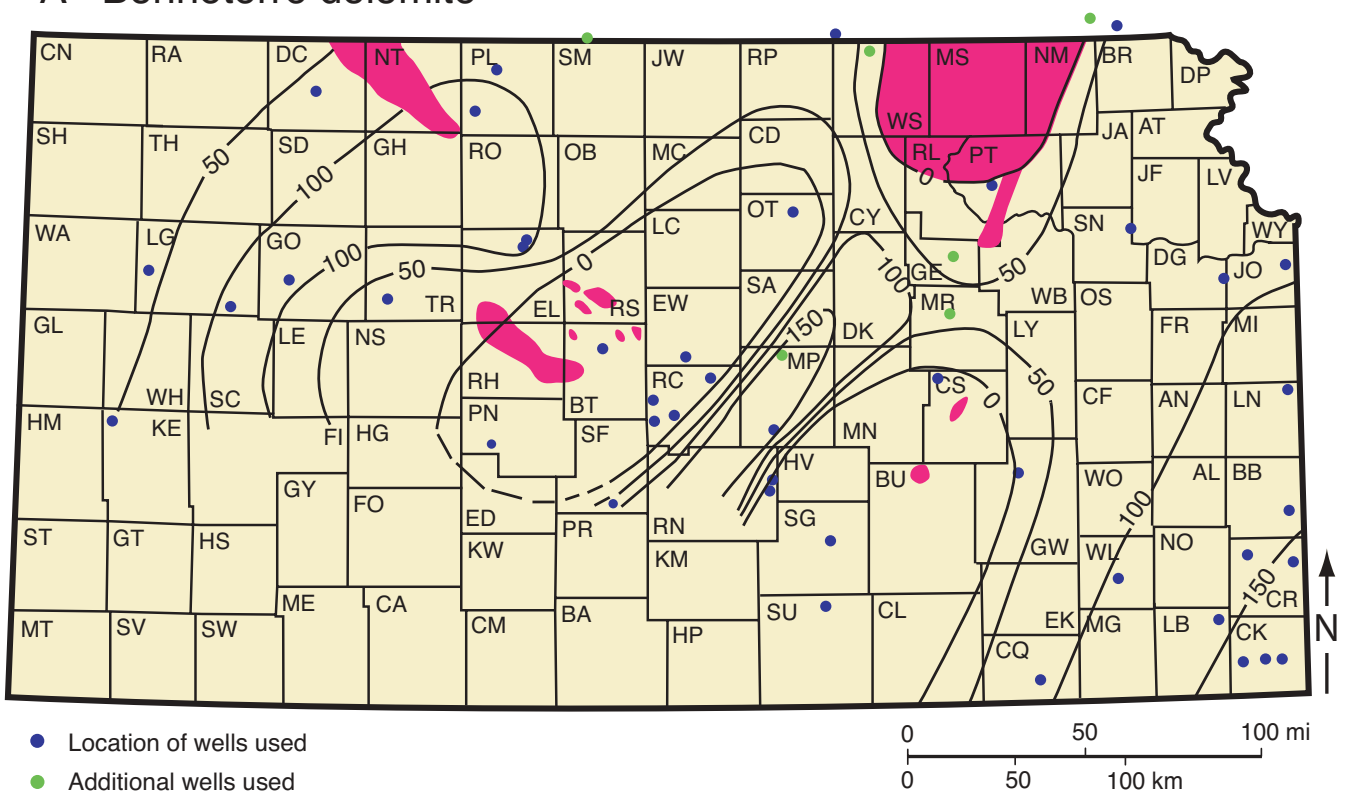

- Additional wells used

Areas where Upper Cambrian and Lower Ordovician rocks are absent by reason of post-Cotter erosion

Thickness contour interval - $50 \mathrm{ft}$

\section{$\mathrm{B}$ - Eminence dolomite}

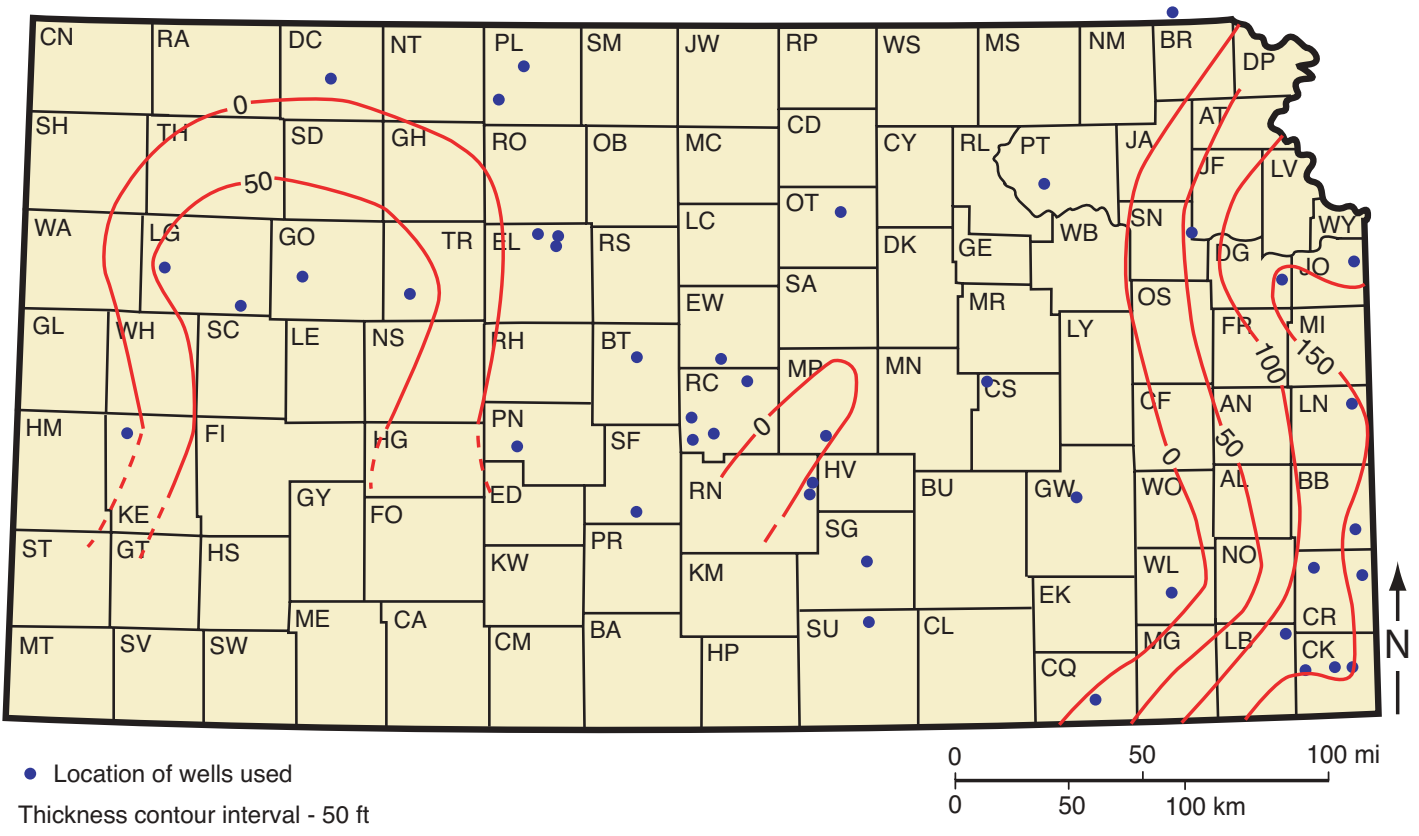

FIGURE 2 (this page and following two pages). Thickness maps of Cambrian-Ordovician (Arbuckle Group) units in Kansas. A) Bonneterre dolomite. B) Eminence dolomite. C) Van Buren-Gasconade dolomites. D) Roubidoux dolomite. E) Jefferson City-Cotter dolomites. From Keroher and Kirby (1948). 


\section{C - Van Buren-Gasconade dolomites}

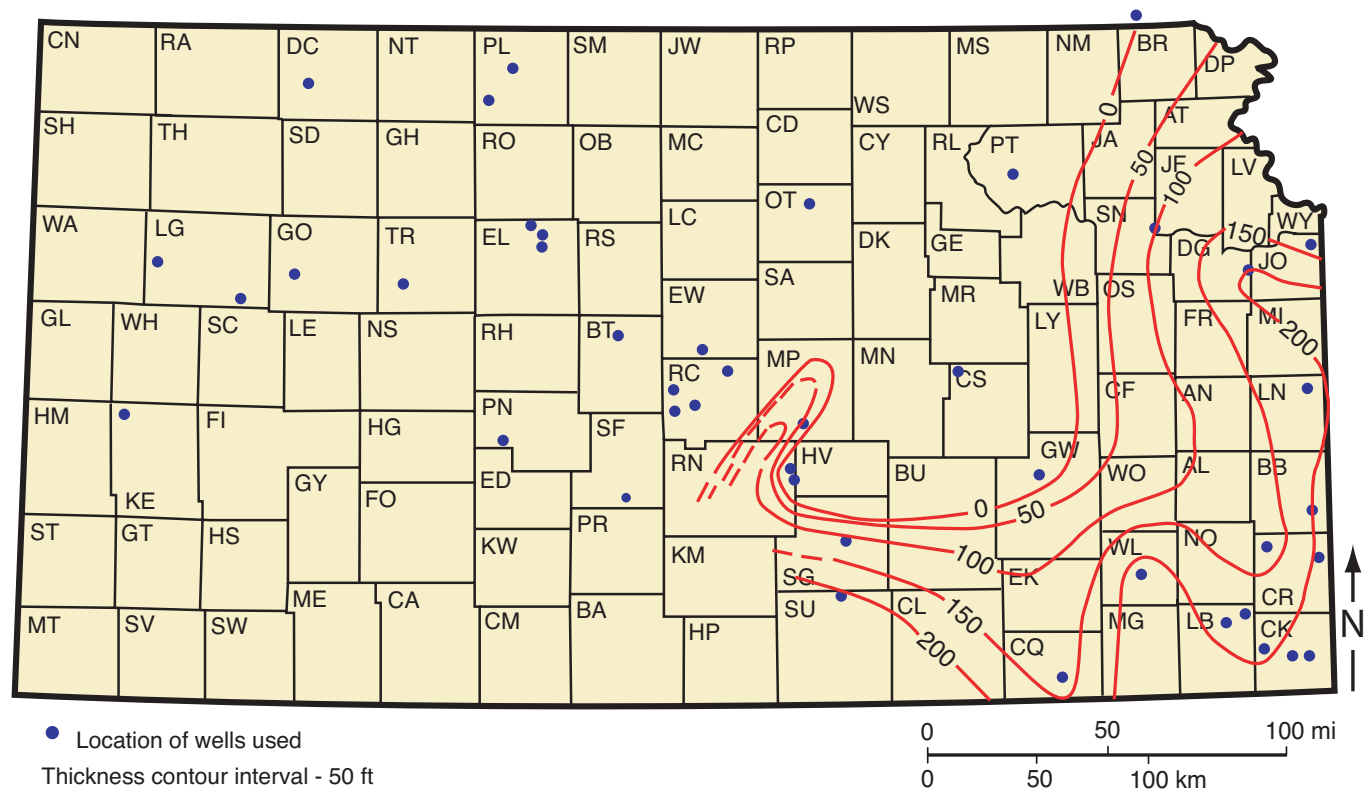

\section{D - Roubidoux dolomite}

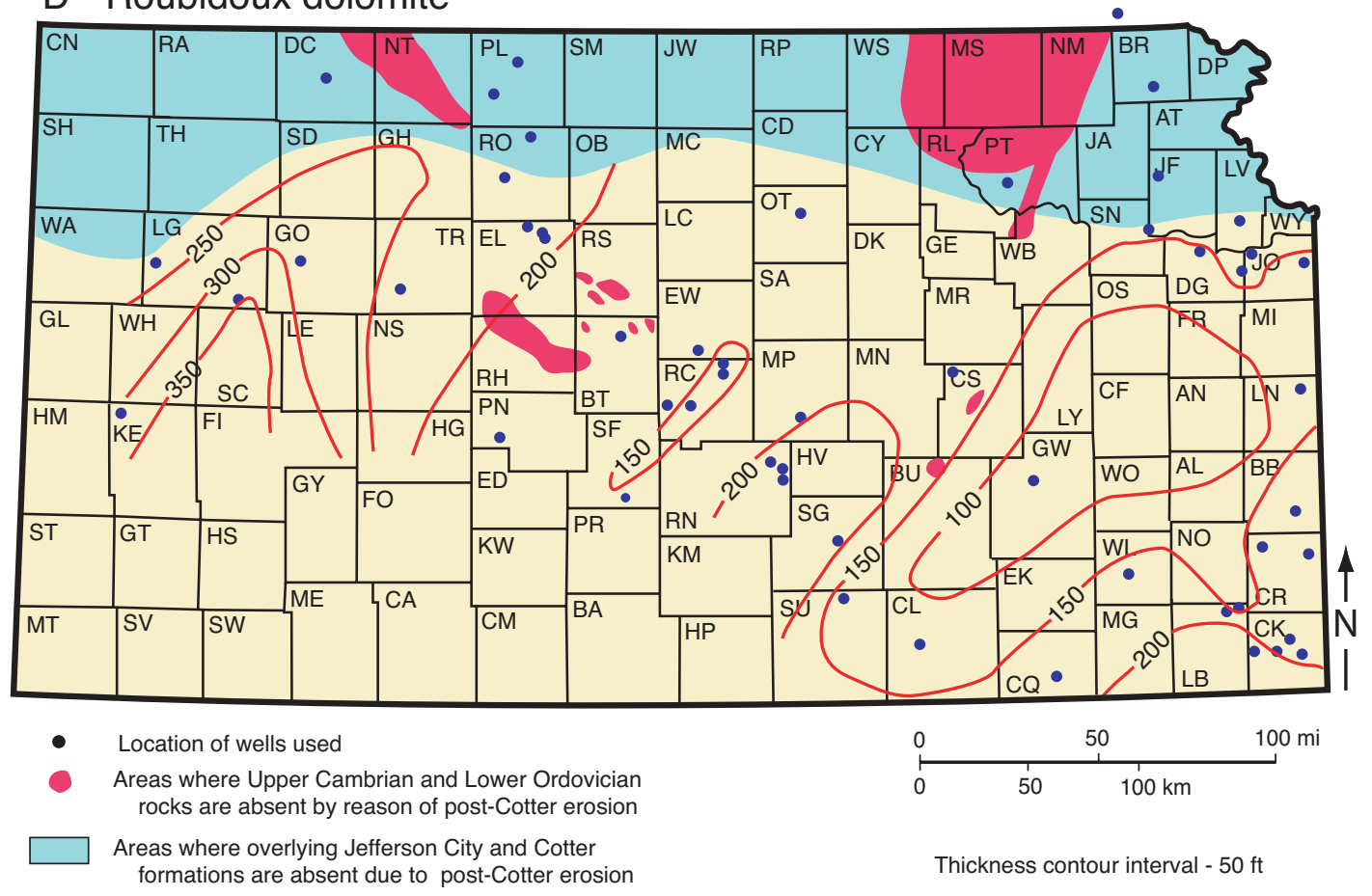




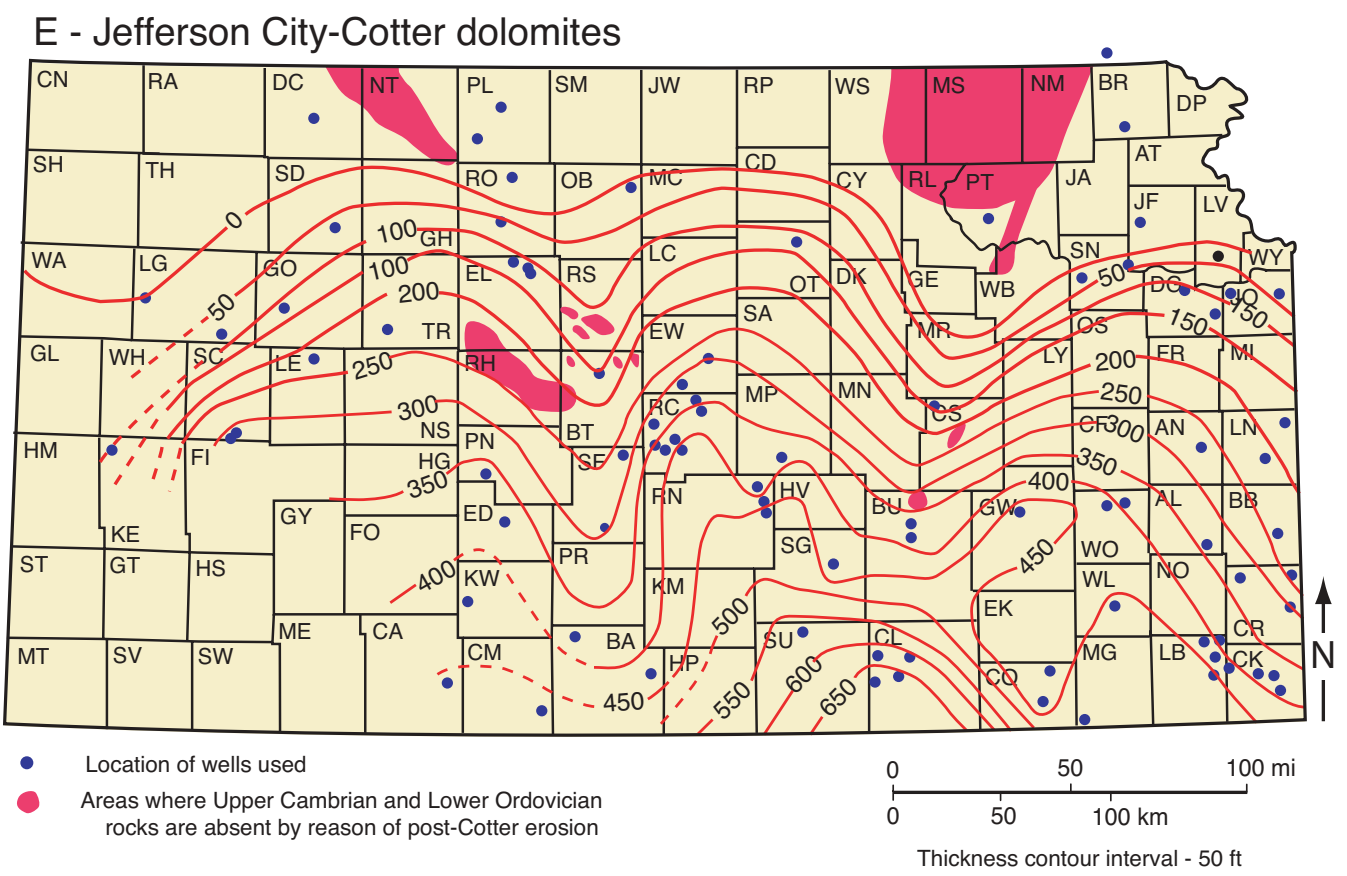

increase in thickness considerably in that direction. Arbuckle strata are within $500 \mathrm{ft}$ of the surface in the southeastern portion of the state and the depth to the top increases westward to more than $6,000 \mathrm{ft}$ below the present surface.

Keroher and Kirby (1948) described the Lamotte Sandstone (ranging from 0 to $130 \mathrm{ft}$ thick) as unconformably overlying the Precambrian basement and occurring in eastern and western Kansas where overlain by the Bonneterre Dolomite. The Lamotte Sandstone is a coarse, subangular to rounded, arkosic sand becoming finer in the upper part and grading into the overlying Bonneterre Dolomite. The Bonneterre Dolomite (0-189 $\mathrm{ft}$ ) is widespread in eastern and western Kansas and absent in central Kansas. It is described as coarsely crystalline to dense, fine-grained, glauconitic dolomite, locally brown in color and containing fine, silty sand, which is coarser near the Lamotte Sandstone. Green doloclastic shale is common in the upper part. The Eminence Dolomite (0-175 ft) unconformably overlies the Bonneterre Dolomite and only occurs in limited areas in eastern and western Kansas. It is described as a gray to white, coarsely crystalline dolomite containing vitreous and quartzose chert. Green shale and pyrite are common in the lower part. Doloclastic chert occurs in western Kansas. The Gunter Sandstone Member (0-45 ft) of the undifferentiated Gasconade Dolomite and Van Buren Formation (now referred to just the Gasconade Dolomite) unconformably overlie the Eminence Dolomite. It consists of dolomitic sandstone, with polished and rounded quartz grains. The rest of the undifferentiated Gasconade Dolomite and Van Buren Formation (0-233 ft) occurs only in eastern Kansas and rests on the Precambrian basement in south-central Kansas. It consists of light-gray, coarsely crystalline dolomite containing much white, dense, and blue, translucent chert. The Roubidoux Dolomite (0-350 ft) unconformably overlies and is the most widely distributed Lower Ordovician unit in Kansas. It consists of white, very coarsely crystalline dolomite containing abundant fine, bright, angular sand. The undifferentiated Cotter Dolomite and Jefferson City Dolomite (0-667 feet) unconformably overlies the Roubidoux Dolomite and is widespread in Kansas, only being absent in northern Kansas. This unit is characterized by a great variety of cherts and dolomites, and brown oolites. Intercalated sand lenses are common.

Moore et al. (1951) recognized the need for a published rock column for Kansas that summarized the knowledge of the sequence of strata for that time. They defined the Arbuckle Group to include the Cotter Dolomite and Jefferson City Dolomite, Roubidoux Formation, Gasconade Dolomite, Van Buren formation, and Eminence Dolomite.

McCracken (1955) continued the theme of insoluble residues for correlation of upper Arbuckle strata from Missouri across southern Kansas (fig. 3). He divided Lower Ordovician (Canadian) strata into 19 subdivisions based on type of residue assemblages, their percentages, pattern of sedimentary cycles, and repetition of occurrences. The 19 zones were defined based on their recognition throughout the state of Missouri. McCracken then recognized that some of the zones could be identified in various areas of the midcontinent region, noting that zones 1-12 (Roubidoux, Jefferson City, Cotter) could be correlated in Kansas, but that zones 13-19 were likely not preserved in any of the Kansas Arbuckle section.

Lee (1956) further utilized the results of McCracken (1955) in a study of the stratigraphy and structure of the 


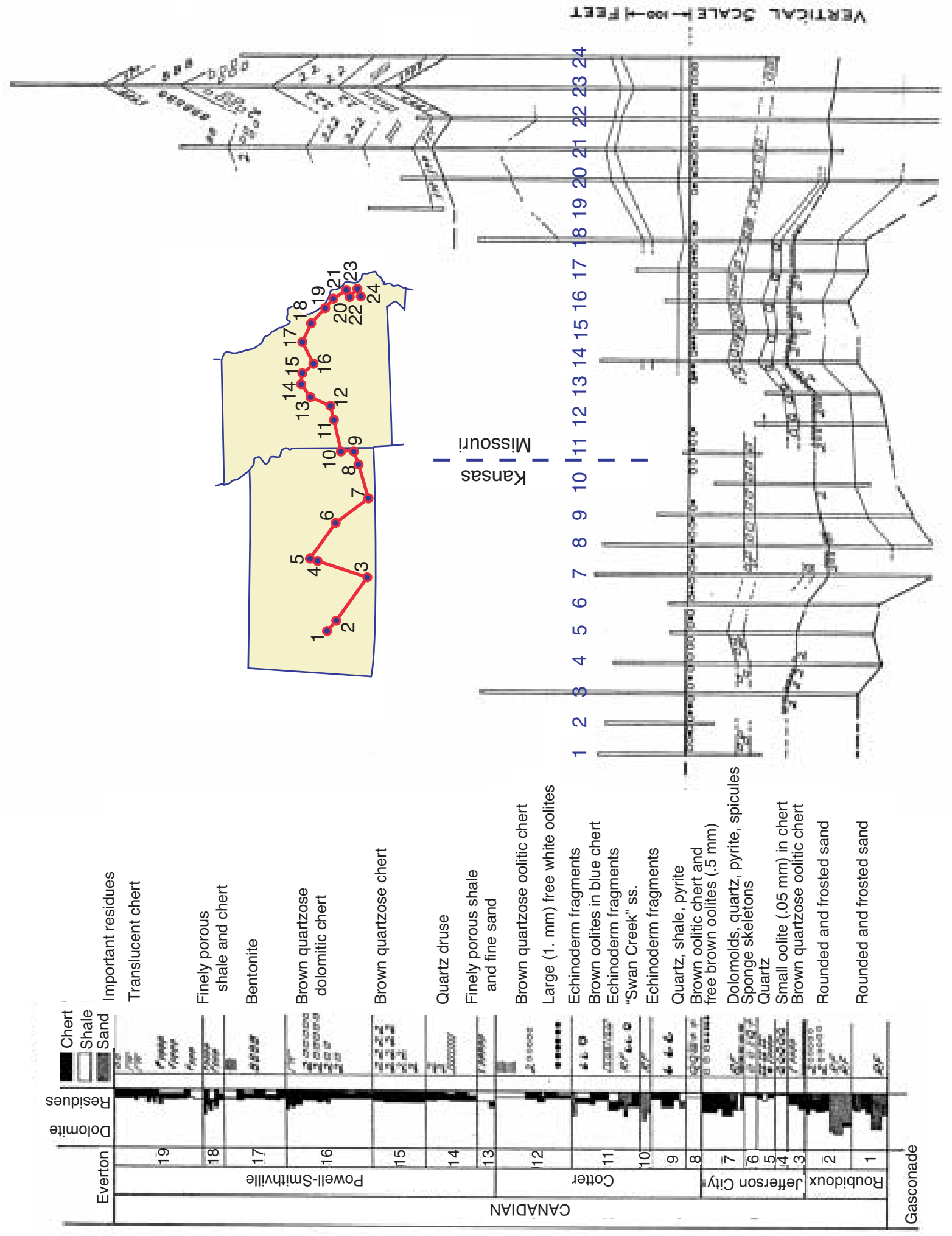


Salina basin area. He acknowledged that the original Arbuckle limestone of Oklahoma and the corresponding Cambrian-Ordovician rocks of Missouri had been subdivided into mappable formations, but thought it was still convenient to regard them collectively as the Arbuckle Group. Lee noted that the Bonneterre through Smithville formations were currently regarded as formations included in the Arbuckle Group. Lee (1956) stated that correlation of formations between Missouri and Kansas (fig. 4) was complicated because some formations wedge out toward the west and facies changes made some of the criteria used by McCracken (1955) in Missouri difficult to use in some parts of Kansas.

Walters (1958) indicated that Arbuckle beds in central Kansas, having a thickness of $550 \mathrm{ft}$, including $300 \mathrm{ft}$ at the top of tan and brown dolomites with oolitic cherts, were the probable correlatives of the Cotter, Jefferson City, and Roubidoux of Missouri. Underlying was $120 \mathrm{ft}$ of white, coarsely crystalline dolomite with low insoluble residue content and $40 \mathrm{ft}$ of sandy dolomite, both of probable Ordovician age. The lowest unit, resting on the Precambrian and thought to be Upper Cambrian, was 110 $\mathrm{ft}$ of clean recrystallized sand with no glauconite. This unit was thought to be the likely equivalent to the Lamotte or Reagan sandstone. Walters (1958) did not include the sandstone in the Arbuckle in a stratigraphic sense but included it in isopach-map construction citing the common oil-field practice of a loosely termed "Arbuckle Group.”

\section{0-Present}

By the 1960's the distribution of the various units of Cambrian-Ordovician strata in Kansas was well documented. However, usage of the term "Arbuckle Group" would continue to vary from author to author. Some included the units between the Simpson Group and Reagan or Lamotte Sandstone, whereas others excluded the Bonneterre or both the Bonneterre and Eminence from the Arbuckle Group (Merriam, 1963; Zeller, 1968). The last accepted published stratigraphic chart of Kansas (Zeller, 1968) included the Eminence Dolomite through the undifferentiated Cotter Dolomite and Jefferson City Dolomite in the Arbuckle Group (fig. 5). Goebel (in Zeller, 1968) revised the Van Buren-Gasconade unit designated by Keroher and Kirby (1948) to just the Gasconade Dolomite, citing the difficulty in separating these units in the subsurface of Kansas, and the abandonment of the term Van Buren by the Missouri Geological Survey.

Despite the Arbuckle being subdivided into separate units and defined confidently in places (e.g. Zeller, 1968), the Arbuckle term continued to be variably used. This is exemplified by Cole (1975) who produced isopach maps of Ordovician-Cambrian rocks in Kansas, including the Arbuckle Group, from thousands of well data compiled from wells drilled up to 1965. Although acknowledging the work that had subdivided the Arbuckle, Cole (1975) noted the difficulty of mapping the units in the

\begin{tabular}{|c|c|}
\hline Mismouri * & Eatern Kanas \\
\hline St. Peter sandstone & Rocks of Simpson age \\
\hline \multicolumn{2}{|c|}{ Arbuckle group } \\
\hline \multicolumn{2}{|c|}{ Early Ordotician } \\
\hline $\begin{array}{l}\text { Smithville formation * } \\
\text { Powell dolomite } \\
\text { Cotter dolomite } \\
\text { Jefferson City doloenite } \\
\text { Roubidoux formation } \\
\text { Gasconade dolomite }\end{array}$ & $\begin{array}{l}\text { Absent } \\
\text { Absent } \\
\text { Undiferentisted Cotter and } \\
\text { Jefierson City dolomites } \\
\text { Roubidoux dolomite } \\
\text { Gascooade dolomite } f\end{array}$ \\
\hline \multicolumn{2}{|c|}{ Late Cambrian } \\
\hline $\begin{array}{l}\text { Eminence dalonite } \\
\text { Potosi dolomite } \\
\text { Derby and Doe Run dolomites } \\
\text { Davis formation } \\
\text { Boaneterre dolomite }\end{array}$ & $\begin{array}{l}\text { Eminence dolomite f } \\
\text { Absent I } \\
\text { Absent ff } \\
\text { Absent f } \\
\text { Bonneterre dolomite }\end{array}$ \\
\hline \multicolumn{2}{|c|}{ Pre-Arbuckle } \\
\hline Lamotte sandstone & Lamotte (Reagan) sandstone \\
\hline
\end{tabular}

FIGURE 4. Relationship between Missouri and Kansas of the formations considered to be Arbuckle Group by Lee (1956). 


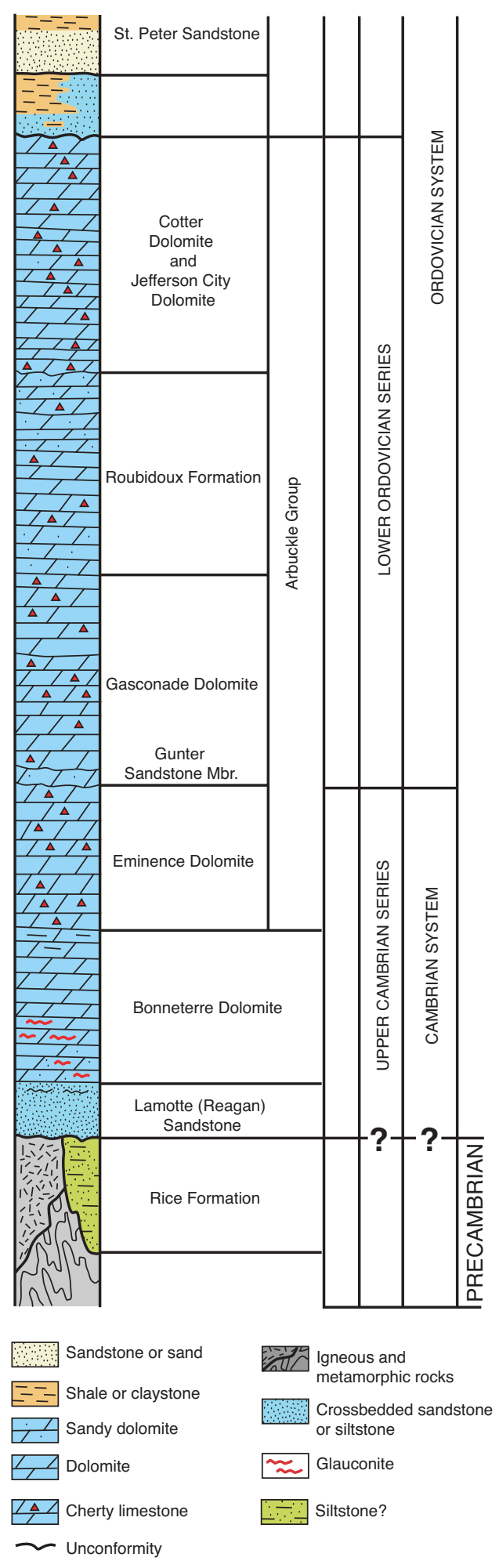

FIGURE 5. A portion of the stratigraphic chart from Zeller (1968) showing Arbuckle Group units. 
subsurface, and therefore lumped all Upper CambrianLower Ordovician strata below the Simpson (and including the Lamotte and Reagan sandstones, and the Bonneterre formation) into his Arbuckle Group.

\section{Description of Currently Recognized Interval}

The Arbuckle Group is part of the Sauk Sequence of Sloss $(1963,1988)$. The basal contact of the Arbuckle Group in Kansas is an unconformity on Precambrian rocks (sub-Sauk surface of Sloss, 1963, 1988) or Cambrian strata (Zeller, 1968; Cole, 1975). As throughout much of the craton of North America, the upper contact of the Arbuckle Group in Kansas is a major unconformity. This unconformity has traditionally been thought to represent the sub-Tippecanoe unconformity at the top of the Sauk Sequence (Sloss, 1963, 1988). However, other workers suggest the upper boundary of the Sauk Sequence is better placed in the Middle Ordovician (Whiterockian) (Derby, Bauer, et al., 1991). In either case, the upper contact of the Arbuckle Group in Kansas is a significant unconformity. Middle Ordovician Simpson sandstone and shale typically unconformably overlie the Arbuckle in Kansas, although Viola Shale or Mississippian strata locally directly overlie Arbuckle rocks. In areas of greatest post-Ordovician uplift, such as the Central Kansas uplift, the Arbuckle Group may be unconformably overlain by beds as young as Pennsylvanian (Merriam, 1963; Cole, 1975).

In 1998, the Lexicon of Geologic Names of Kansas (through 1995) was published by the Kansas Geological Survey (Baars and Maples, 1998). That publication showed the Arbuckle Group to include the Cotter Dolomite, Jefferson City Dolomite, Roubidoux Formation, and the Gasconade Dolomite (including the Gunter Sandstone Member). None of the Upper Cambrian units was included. The 1998 Lexicon defers to the lastaccepted published stratigraphic guide for the state (Zeller, 1968) in the case of contention with stratigraphic terms. Therefore, descriptions from Zeller (1968), which included the Eminence Dolomite in the Arbuckle Group, are considered as current and are repeated below.

Eminence Dolomite: Cherty, buff to white, very coarsely crystalline dolomite makes up the Eminence. Vitreous semitranslucent chert contains cavities encrusted by finely crystalline quartz. The chert commonly is mixed so intimately with the dolomite that insoluble residues consist dominantly of chert with lacelike, interconnecting molds of dolomite crystals. An angular unconformity separates the Eminence from the Bonneterre. Occurrence of Eminence deposits in eastern Kansas is confined mostly to a belt three counties wide bordering Missouri. It is recognized also in parts of western Kansas. The formation thickens eastward from 0 to more than $150 \mathrm{ft}$ at the Missouri state line. Thicknesses of 40 to $90 \mathrm{ft}$ are reported in west-central Kansas.
Gasconade Dolomite: Consists mainly of cherty, coarsely granular dolomite. The chert in the upper part, which is dense and gray to dark-bluish-gray, grades downward into white, dense, quartzose chert. The Gasconade is unconformable on Eminence beds and probably also on Bonneterre, Lamotte, and Precambrian beds. Gasconade rocks are reported in the subsurface in a belt along the Missouri state line. The thickness ranges from 0 to more than $200 \mathrm{ft}$ in southeastern Kansas.

Gunter Sandstone Member: This member, present at the base of the Gasconade, is a sandy dolomite.

Roubidoux Formation: In Kansas, this formation consists mainly of sandy dolomite and fine-grained sandstone. Deposition of the Roubidoux seems to have been preceded by folding and erosion of older rocks. Thickness of the formation generally ranges from 150 to $200 \mathrm{ft}$.

Jefferson City Dolomite and Cotter Dolomite: Because the Cotter Dolomite and Jefferson City Dolomite recognized in outcrops are not distinctly separable in the subsurface on lithologic criteria, they are treated as a unit. They consist mainly of coarsely granular, cherty dolomite. The upper part of the sequence includes much oolitic chert, which becomes white and decreases in volume toward the base where white, tripolitic chert becomes abundant. These rocks unconformably underlie different formations, such as the St. Peter Sandstone on the flank of the Southeast Nebraska arch, the Chattanooga Shale on the Chautauqua arch, and Pennsylvanian rocks on parts of the Central Kansas uplift and Nemaha anticline. The Jefferson City Dolomite probably is conformable on the Roubidoux Formation. The Cotter-Jefferson City sequence ranges in thickness from $0 \mathrm{ft}$ in northern Kansas to more than $650 \mathrm{ft}$ in Cowley County in southern Kansas.

\section{Distribution in Kansas}

The Arbuckle is present in most of Kansas and is absent only in areas of northeastern and northwestern Kansas, and over ancient uplifts and buried Precambrian highs (Walters, 1946; Keroher and Kirby, 1948; Cole, 1962, 1975; Denison, 1966) (figs. 1, 2, 6). The Arbuckle is thin to absent in parts of northeastern Kansas due to pre-Simpson uplift and erosion (Newell et al., 1987). The Arbuckle is locally absent on the Nemaha uplift, Cambridge arch, and Central Kansas uplift due to prePennsylvanian erosion (Walters, 1946; Jewett, 1951, 1954; Merriam, 1963). Arbuckle Group rocks occur at depths ranging from about $500 \mathrm{ft}$ in southeastern Kansas to more than 5,000 $\mathrm{ft}$ in southwestern Kansas (Keroher and Kirby, 1948; Cole, 1975). Arbuckle Group rocks thicken as a whole from north to south and are thickest, up to 1,390 ft, in the southeastern corner of Kansas (Cole, 1975) (fig. 7). 


\section{Geologic Setting}

\section{Structural}

Kansas is characterized by broad basins and domes covering thousands of square kilometers. Prominent uplift and subsidence occurred episodically throughout the
Phanerozoic, separated by periods of gradual deformation (Newell et al., 1989). Although the location of the structural features varied somewhat throughout the Paleozoic, there seem to be consistent patterns of repeated localized uplift and subsidence (Baars and Watney, 1991). Two prominent structural uplifts that affect the Paleozoic rocks in Kansas, the Nemaha uplift and Central Kansas uplift (CKU), represent significant Early Pennsylvanian deformation events likely associated with similarly aged

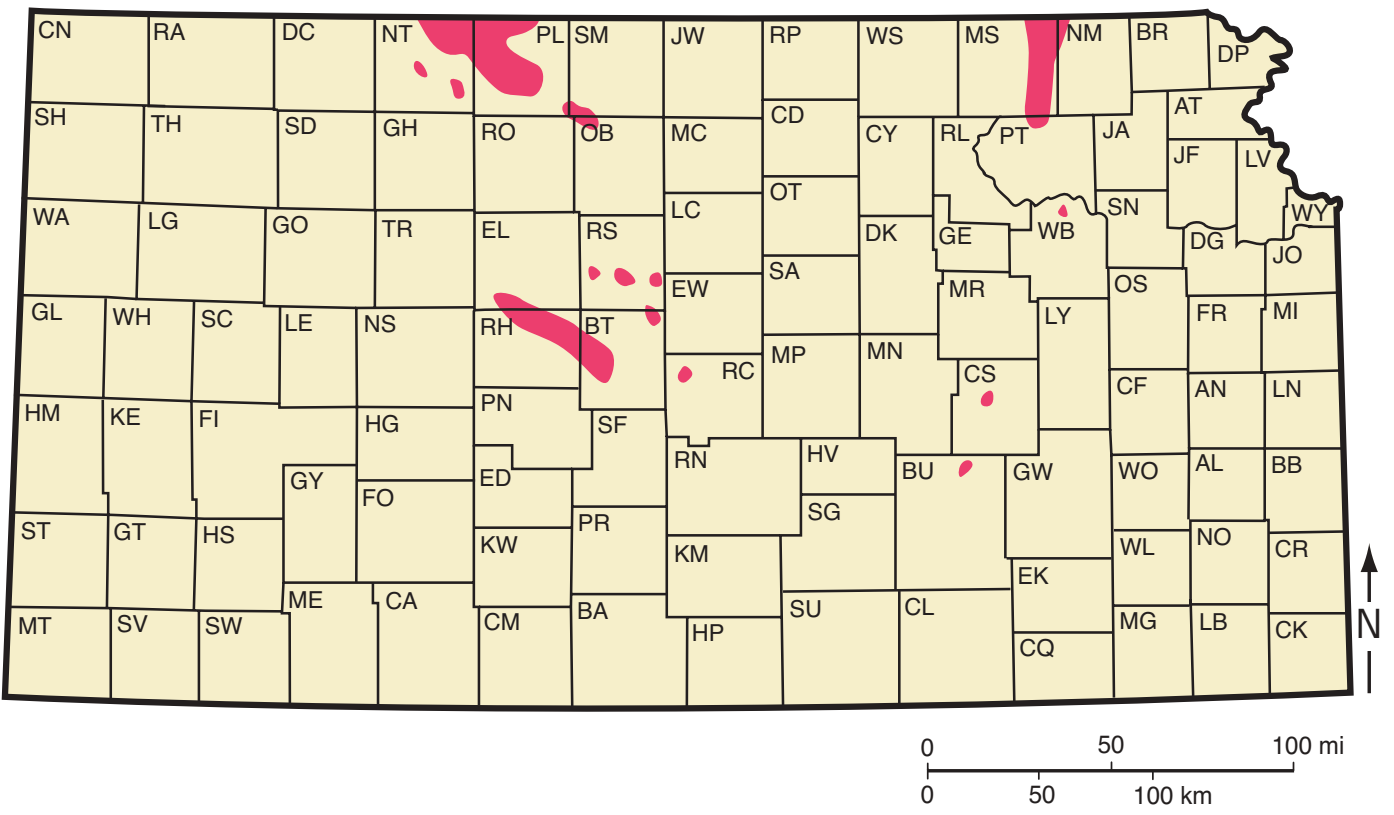

FIGURE 6. Overall distribution of Cambrian-Ordovician strata (yellow area) in Kansas. Arbuckle absent in areas colored pink. From Merriam (1963).

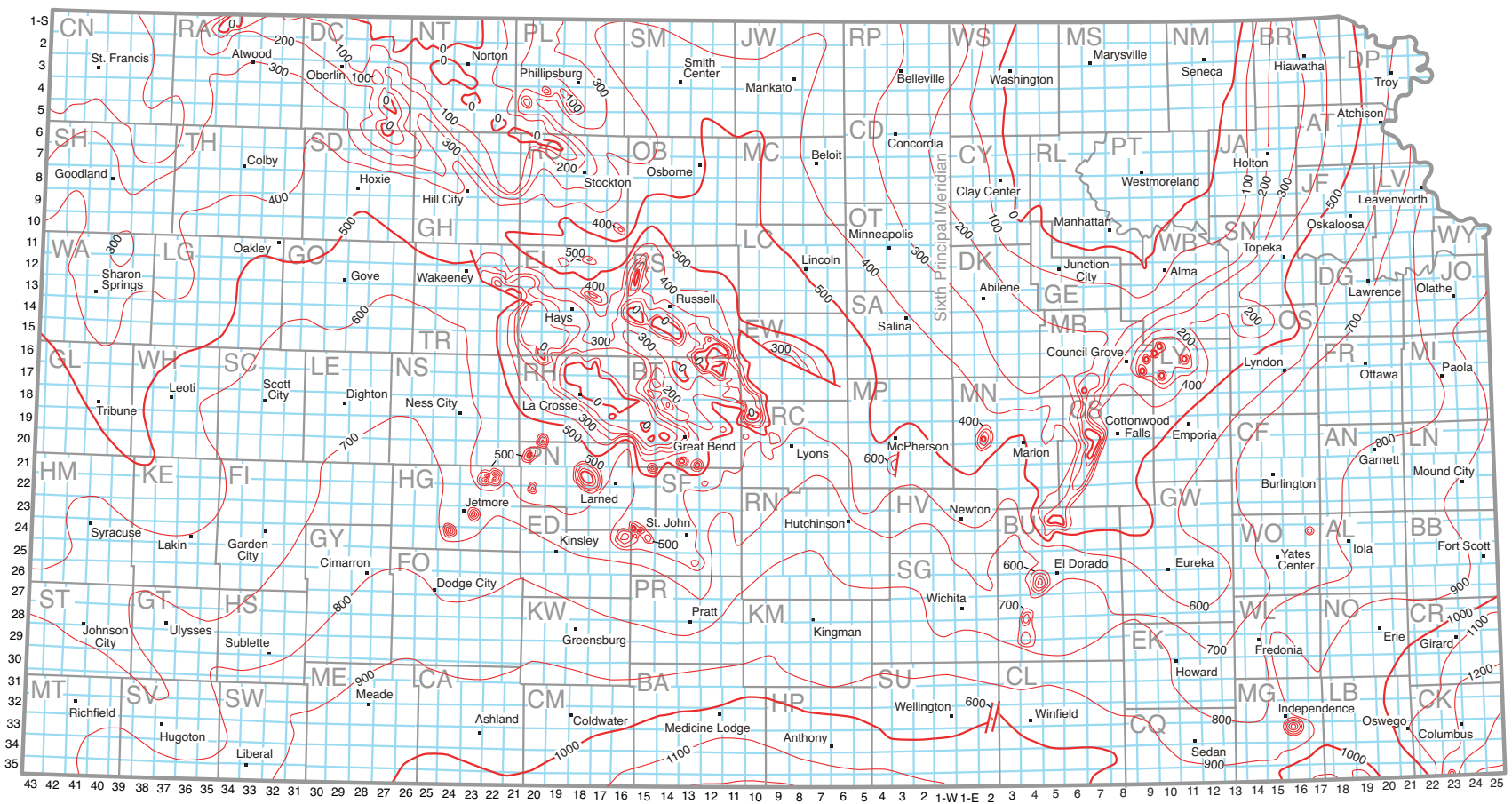

FIGURE 7. Isopach map of Arbuckle Group strata (base Simpson to Precambrian) from well data up to 1965. Contour interval 100 ft. From Cole (1975). 
plate convergence along the Ouachita Mountains orogenic belt in Arkansas (Newell et al., 1989). This uplift and erosion locally affected Arbuckle strata, especially on the Central Kansas uplift where Pennsylvanian strata directly overlie Arbuckle strata, or basement rocks where Arbuckle strata are absent. The Midcontinent Rift System and related Humboldt Fault Zone constitute a northnortheast by south-southwest-trending fault swarm that was reactivated several times during the Paleozoic. Local uplift and interstratal truncation suggest rejuvenation of structural blocks during the Late Ordovician, before the better known Pennsylvanian uplift and erosion of the major structural features (Baars and Watney, 1991).

Structural maps of Precambrian basement (fig. 8) and isopach maps (figs. 7, 9) of the Arbuckle indicate the presence of elements of the CKU and Nemaha Ridge prior to Arbuckle deposition. Deformation during and just post-Arbuckle deposition appears to have been minor.

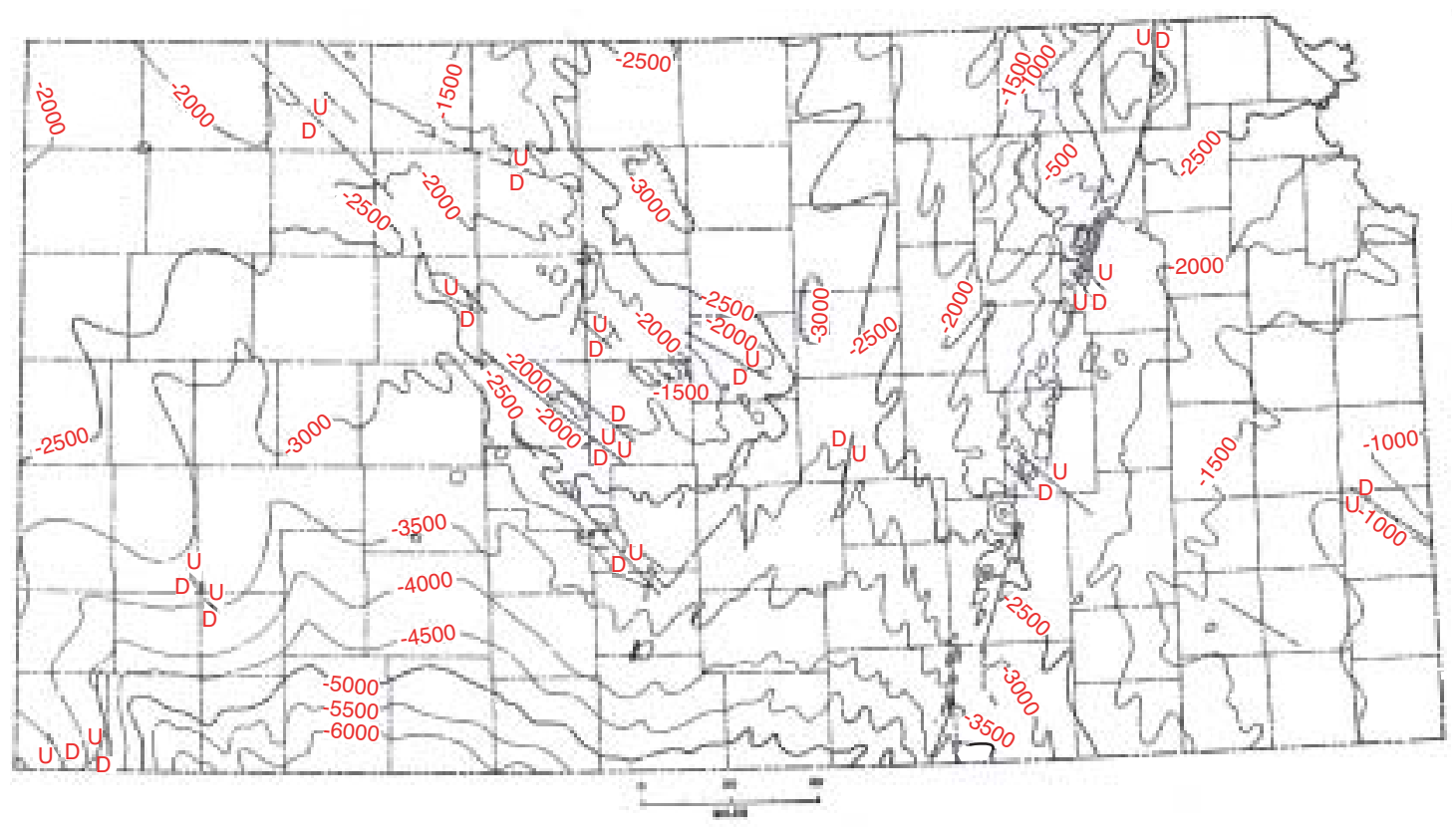

FIGURE 8. Preliminary regional configuration map on top of Precambrian basement complex in Kansas. Contour interval 500 ft. From Merriam (1963).

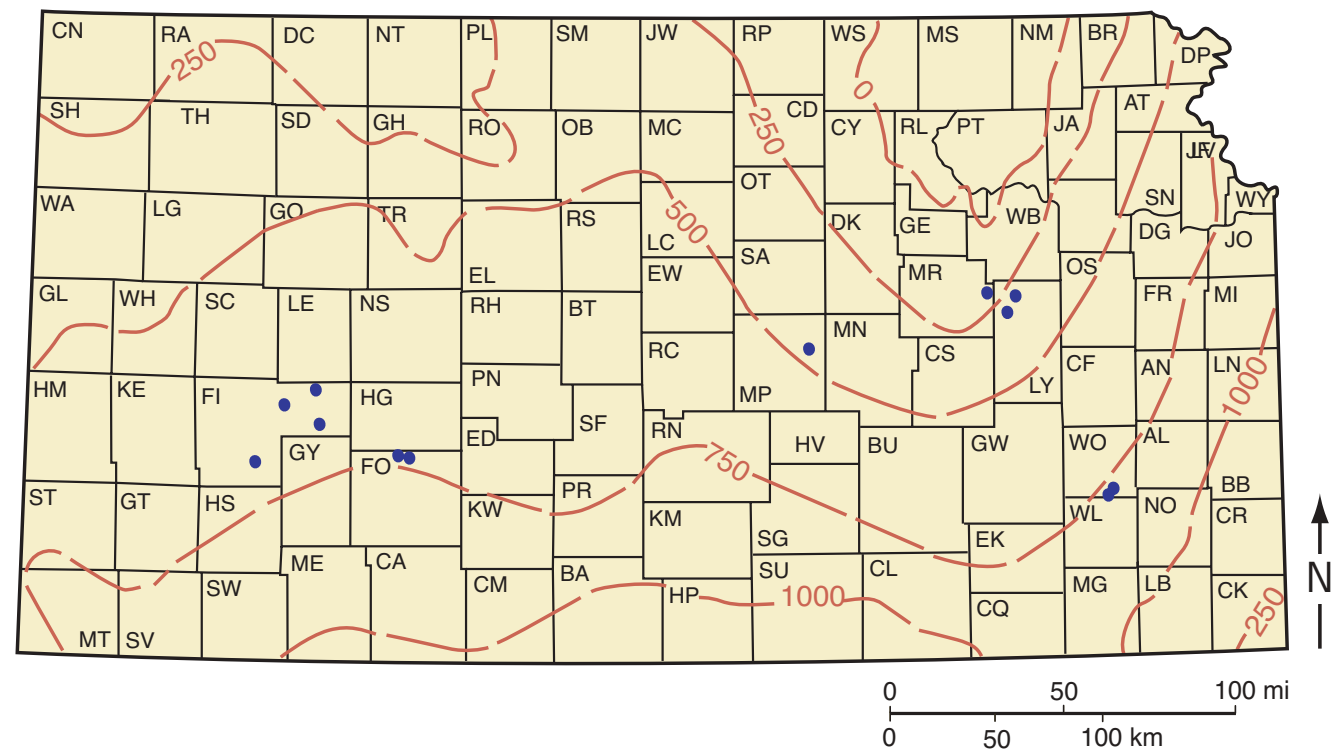

FIGURE 9. Isopachous map showing convergence between top of Precambrian rocks and top of Arbuckle rocks. Southeast Nebraska arch is shown by zero line in northeast. Contour interval is $250 \mathrm{ft}$. From Merriam (1963). 
The most obvious structural feature to have developed prior to Simpson deposition is the Southeast Nebraska arch (Lee, 1956) (fig. 10), which extended into northeastern Kansas. Although not strongly evidenced, Merriam (1963) interpreted mild activity of the CKU during Arbuckle deposition. In addition, extensive differential erosion of Precambrian rocks (presumably in late Precambrian time) resulted in an irregular topography onto which Cambrian-Ordovician strata were deposited (Walters, 1946) (fig. 11).

\section{Paleogeographic and Depositional Setting}

Arbuckle Group rocks are part of the craton-wide Sauk Sequence, which is bounded at its base and top by major interregional unconformities (Sloss, 1963). These interregional unconformities represent major regressions of the sea and erosion and subaerial exposure of vast areas of the craton. The Sauk transgression is the first of several major transgressions in the Paleozoic Era. It began in the Late Proterozoic/Early Cambrian and continued for 100 million years, reaching a maximum in the early

\section{A}

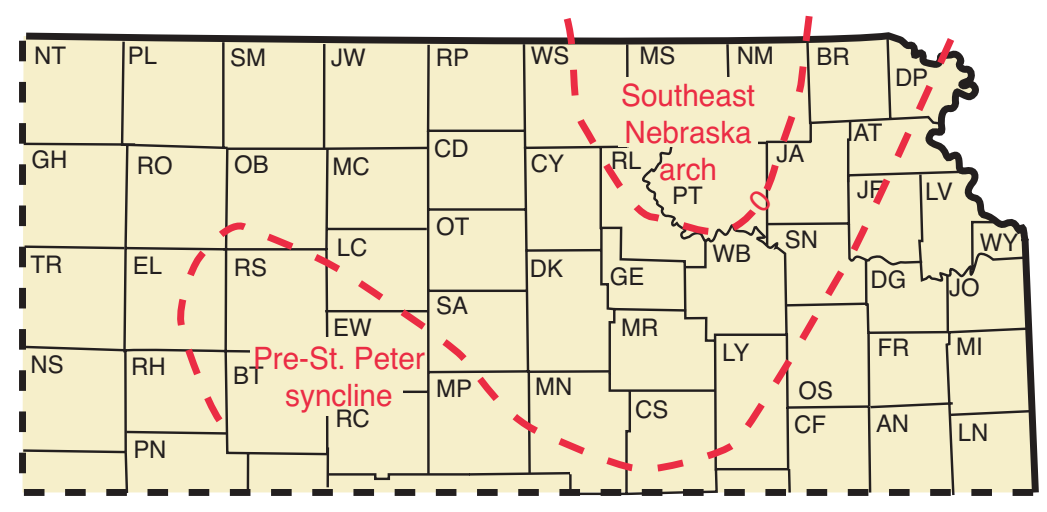

B

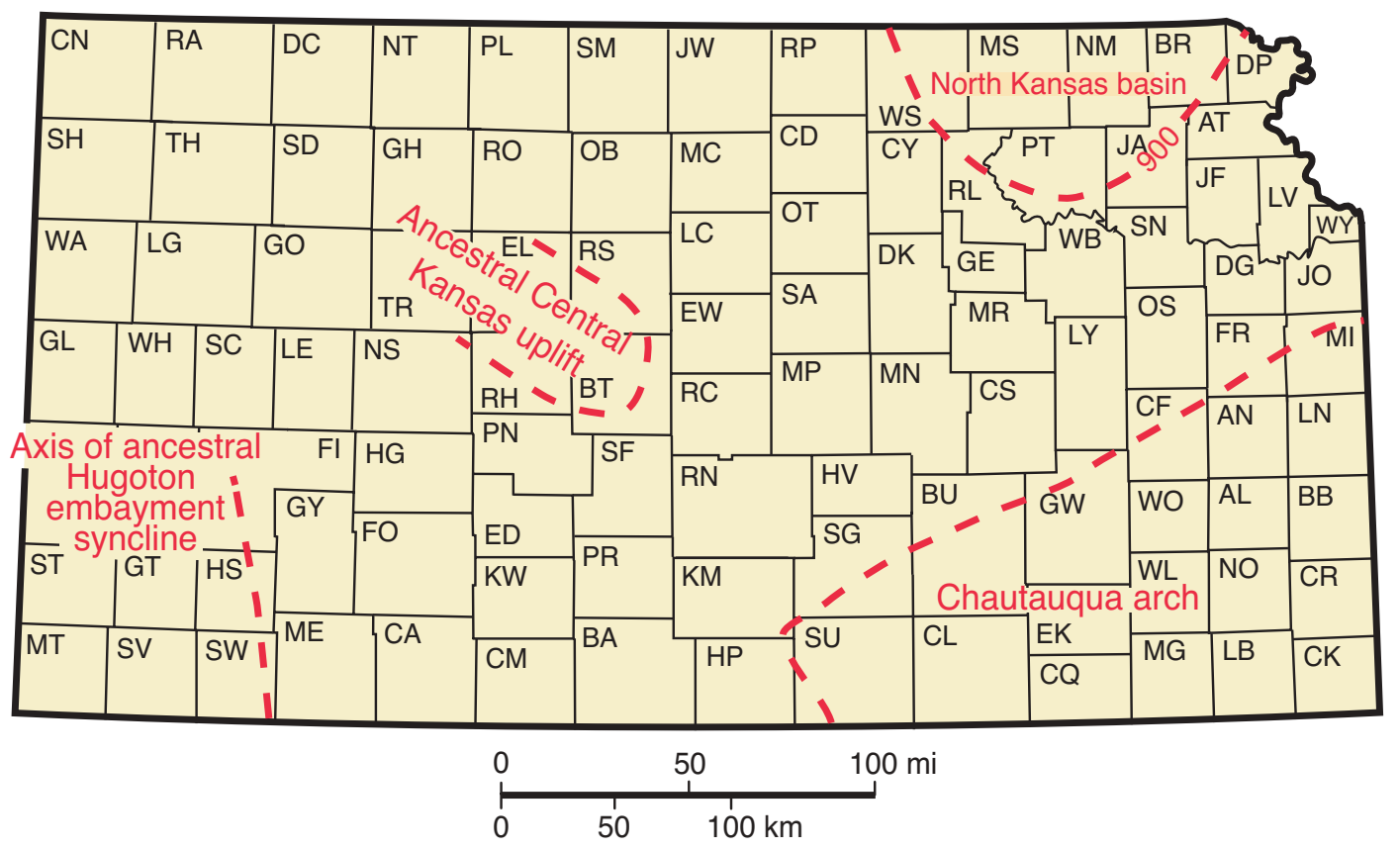

FIGURE 10. Maps showing principal structural features in Kansas. A) Pre-Simpson structure represented by 500-ft thickness lines of Arbuckle dolomite and Reagan sandstone. B) Structural deformation from Arbuckle through Chattanooga time. From Lee (1956). 

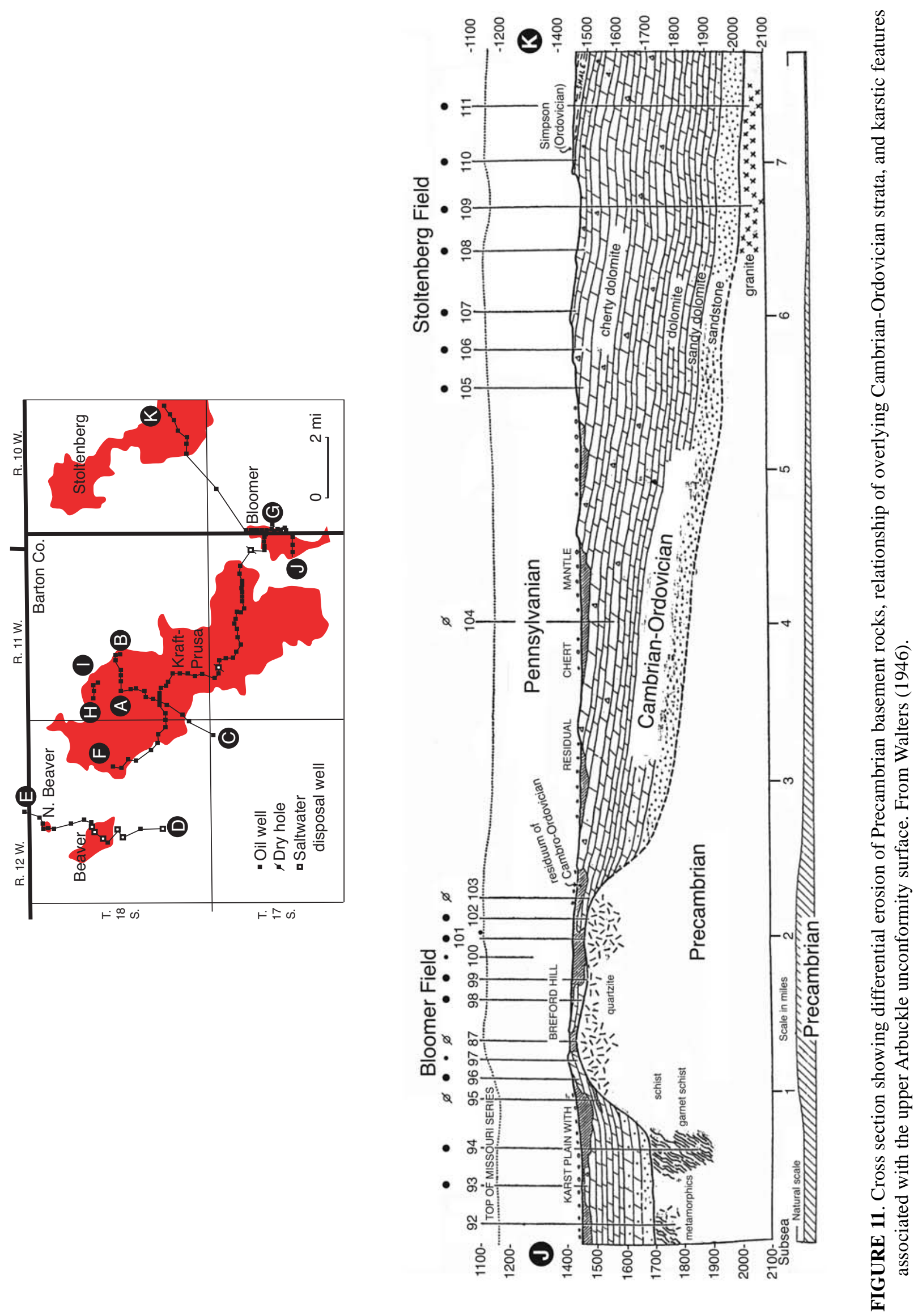
Ordovician. Causes of the Sauk transgression include the melting of Proterozoic ice, increased production of sea floor along the mid-ocean ridges, elevation of ridges, and subsidence of passive continental margins. As a result of these factors, sea level rose and epeiric seas (shallow continental seas) flooded the cratons. As the sea transgressed across the deeply weathered Precambrian igneous and metamorphic basement, basal mature quartz sands (blanket sands) were deposited. These sandy beach facies passed offshore to shallow-water carbonateproducing zones.

Arbuckle shallow-shelf carbonate strata in Kansas and age-equivalent strata elsewhere are part of the Cambrian-Ordovician "Great American Bank" that stretched along the present southern and eastern flanks of the North American craton (Wilson et al., 1991). The bank consists of hundreds of meters of largely dolomitized intertidal to shallow subtidal cyclic carbonate rocks overlain by a regional unconformity (Wilson et al., 1991). The shallow subtidal to intertidal environment persisted throughout Arbuckle depositional time and is reflected in the uniform composition and texture of Arbuckle Group rocks (Bliefnick, 1992).
Kansas during this time was located approximately between 20 to 30 degrees south of the equator (fig. 12), and south of the Transcontinental arch (fig. 13). Early Ordovician sedimentation was different on opposite sides of the Transcontinental arch (Ross, 1976). Shallow marine limestone was deposited on the shelf to the north, and on the shelf to the south predominantly dolomite, cherty dolomite, and dolomitic limestone were deposited, represented by the Arbuckle Group in Kansas and much of Oklahoma (Ross, 1976). Ross (1976) attributes the contrast in sedimentation on opposite sides of the Transcontinental arch to differences in water depth. The shelf north of the arch was in the Ordovician tropical belt. This area likely experienced relatively heavy rainfall and low evaporation and was able to maintain normal marine salinity conditions over a somewhat deeper shelf area (Ross, 1976). The shelf south of the arch was in the Ordovician horse latitudes. This area likely experienced low rainfall and high evaporation which resulted in hypersaline water over a shallower shelf area (Ross, 1976). These latter conditions may have allowed for refluxing of magnesium-rich brines in subtidal waters over the carbonate bottom which in turn would account

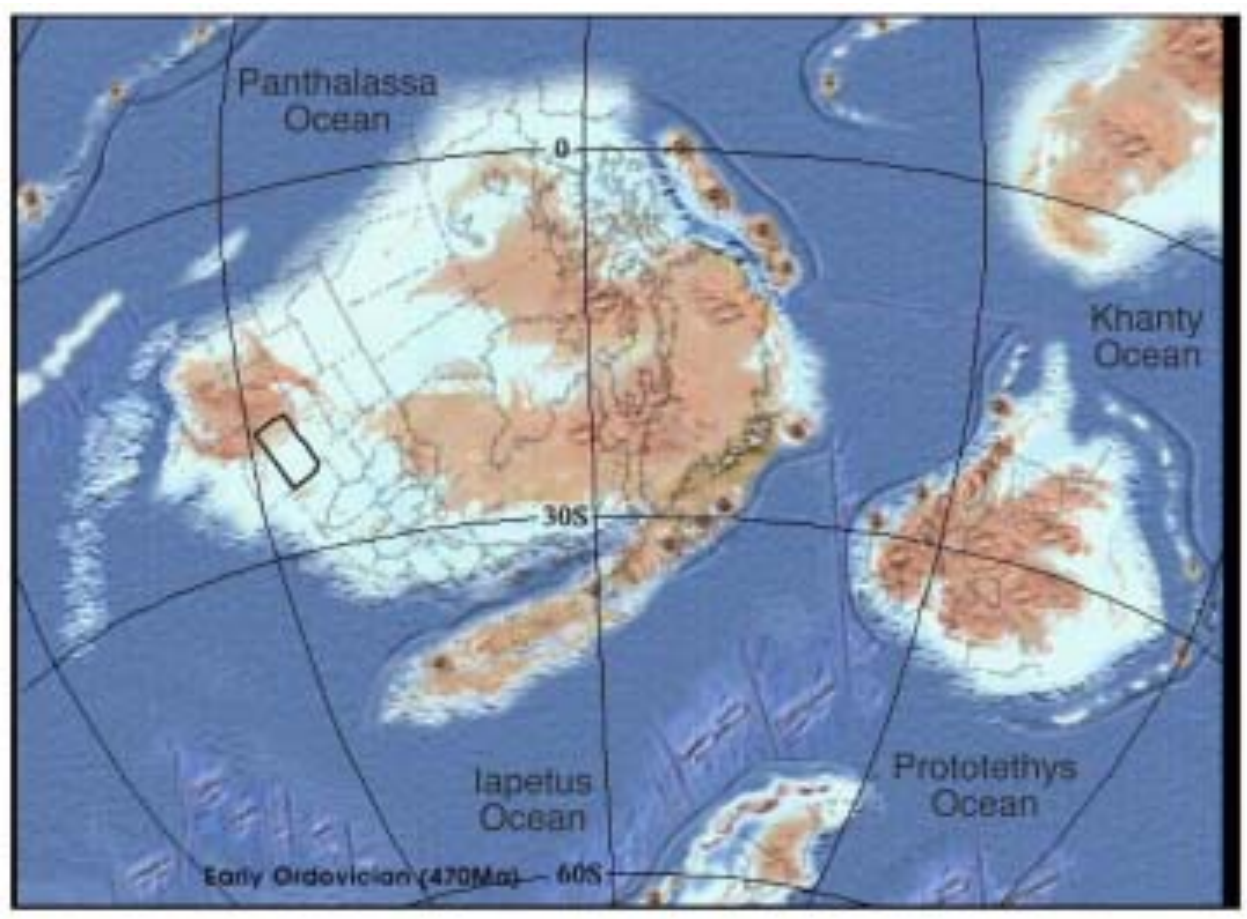

FIGURE 12. Paleogeographic map for Early Ordovician time (470 Ma). Kansas is shown by black outlined area. Tan and brown colors reflect land surface, light blue areas are epicontinental and pericontinental seas, and dark blue represents oceanic areas. Modified from Blakey (http://jan.ucc.nau.edu/ rcb7/); used with permission of author. 


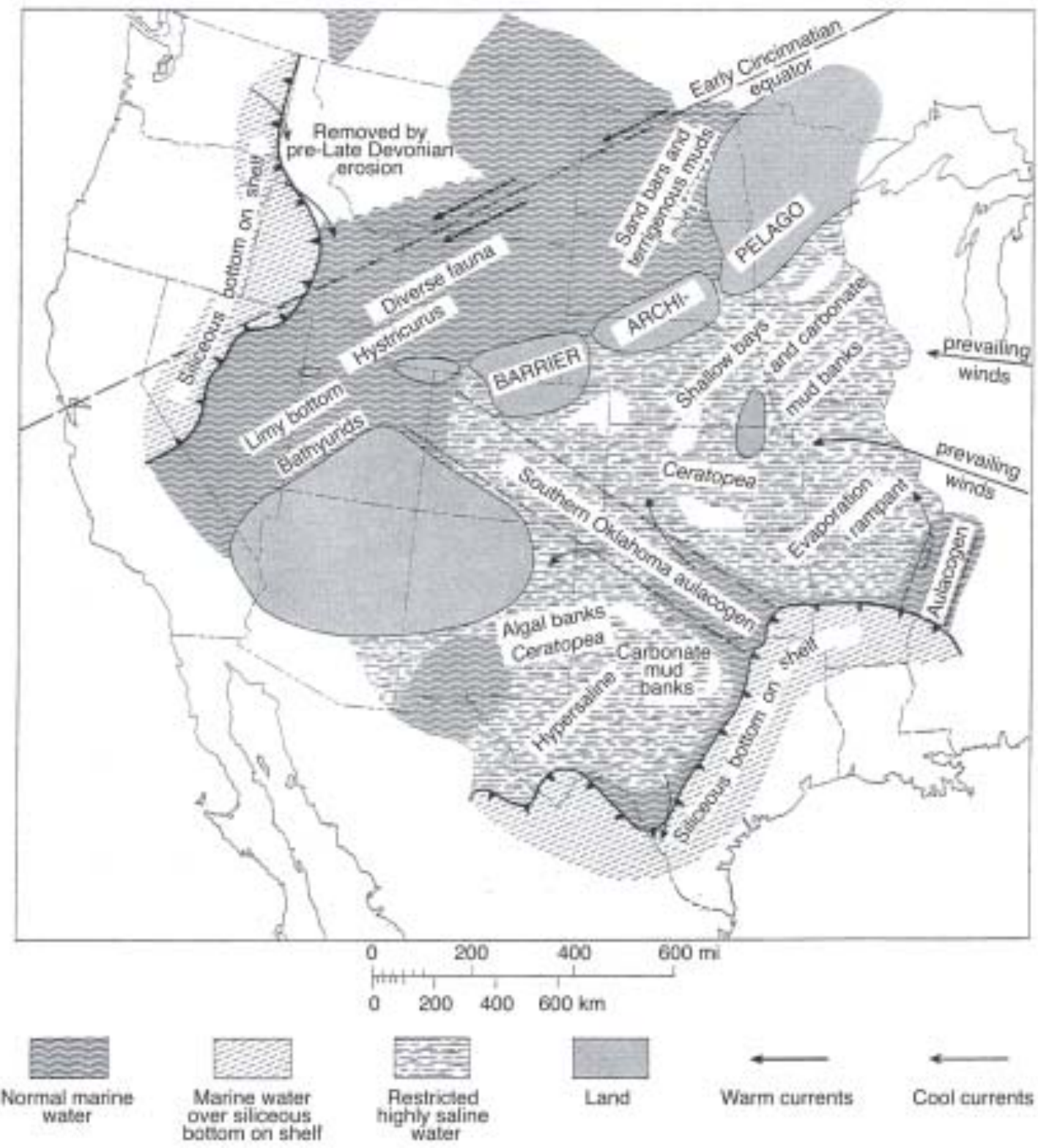

FIGURE 13. Interpretation of Early Ordovician paleoenvironments in the western United States. From Ross (1976); used with permission of University of Wales Press.

for the widespread dolomites on the shelf south of the arch (Harris, 1973).

Unconformities identified within the Arbuckle Group in Kansas are likely major sequence boundaries that correlate to relative sea-level oscillations as documented for this time by Ross and Ross (1988) (fig. 14).

Chenoweth (1968) used overlap relationships of Late Cambrian and Early Ordovician strata with the irregular basement topography in Kansas, Oklahoma, and parts of bordering states to construct paleogeographic maps and to infer depositional histories associated with transgressions and regressions (fig. 15). Chenoweth (1968) acknowledged that in areas containing no Arbuckle strata, it was difficult to determine if the absence was due to non-deposition or erosion.

Sea level fell near the end of the Early Ordovician. Falling sea level drained the continents and left behind a landscape underlain by predominantly carbonate Cambrian-Ordovician strata and Precambrian basement rocks. Deep weathering and erosion produced a regional unconformity and a regionally extensive karst system over most of the North American craton. This regional system has been called the Arbuckle-Ellenburger-Knox-Prairie du Chien-Beekmantown-St. George karst plain (Kerans, 


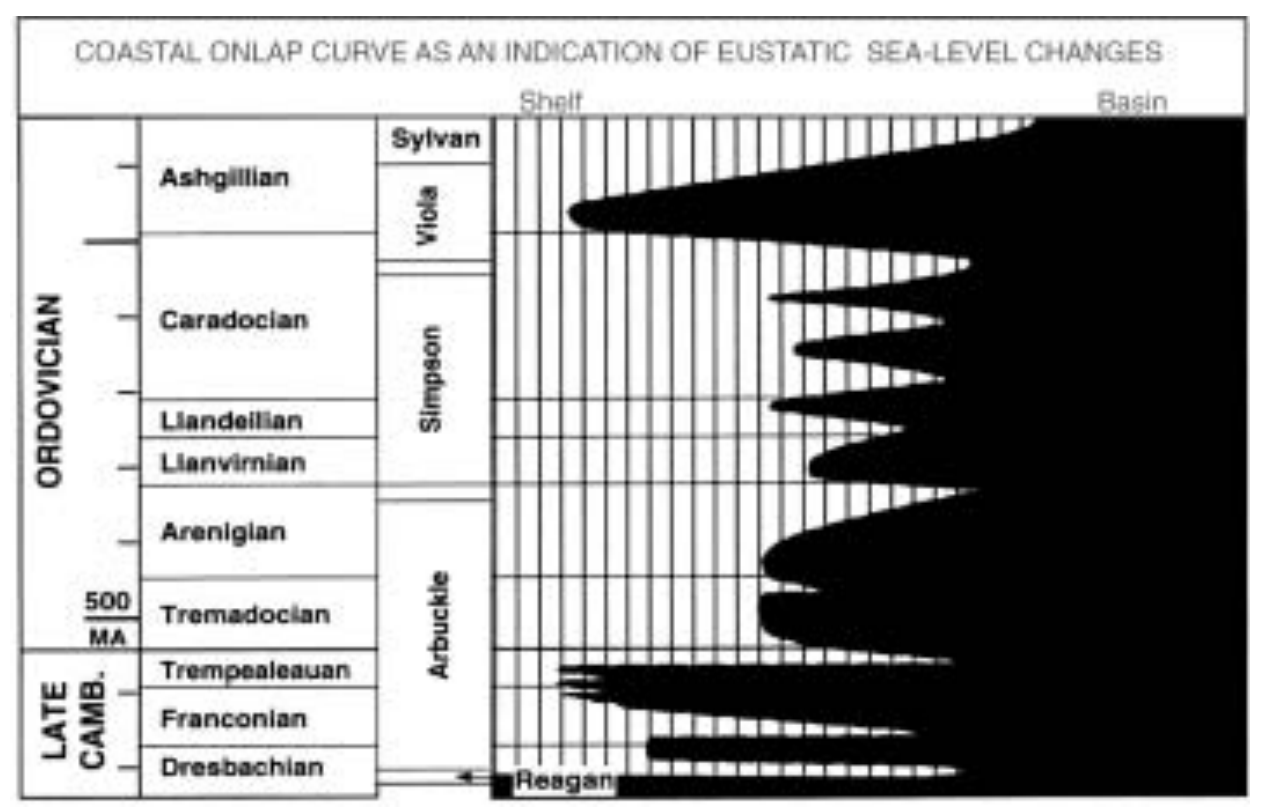

FIGURE 14. Coastal onlap curve for Late Cambrian and Ordovician time based on Ross and Ross (1988). Modified from Shelton and Gerken (1995).

1988). A vast system of caves, sinkholes, joint-controlled solution features, and collapse breccias developed. These features are found throughout the midcontinent in the Arbuckle, Knox, Beekmantown, Prairie du Chien, St. George, and Ellenburger groups (Gore, 1954; Merriam and Atkinson, 1956; Fisher and Barrett, 1985; Kerans, 1990; Hammes, 1997). However, the nature of the postSauk unconformity surface is quite variable (Sloss, 1988). In some areas (such as the Central Kansas uplift) there has been extensive erosion during the post-Sauk regression and numerous additional prolonged periods of subaerial exposure up through the Early Pennsylvanian.

The upper Arbuckle unconformity surface shows a general decrease in elevation to the south (fig. 16), but more complex patterns exist, especially near areas that were structural highs (fig. 17). Many studies over the years have focused on the erosional and karsted nature of the upper Arbuckle surface in Kansas (e.g. Walters, 1946, 1958, 1991; fig. 11). This attention was driven largely by petroleum production in the Arbuckle Group of Kansas, which is associated with the unconformity surface. A recent study by Cansler and Carr (2001) documented karst geomorphology of the upper Arbuckle surface at various scales over the southern part of the Central Kansas uplift in Barton, Ellsworth, Rice, and Stafford counties (fig. 18). They identified major karst landform geometries (dolines, cockpits) and karst erosional features related to groundwater sapping processes. 

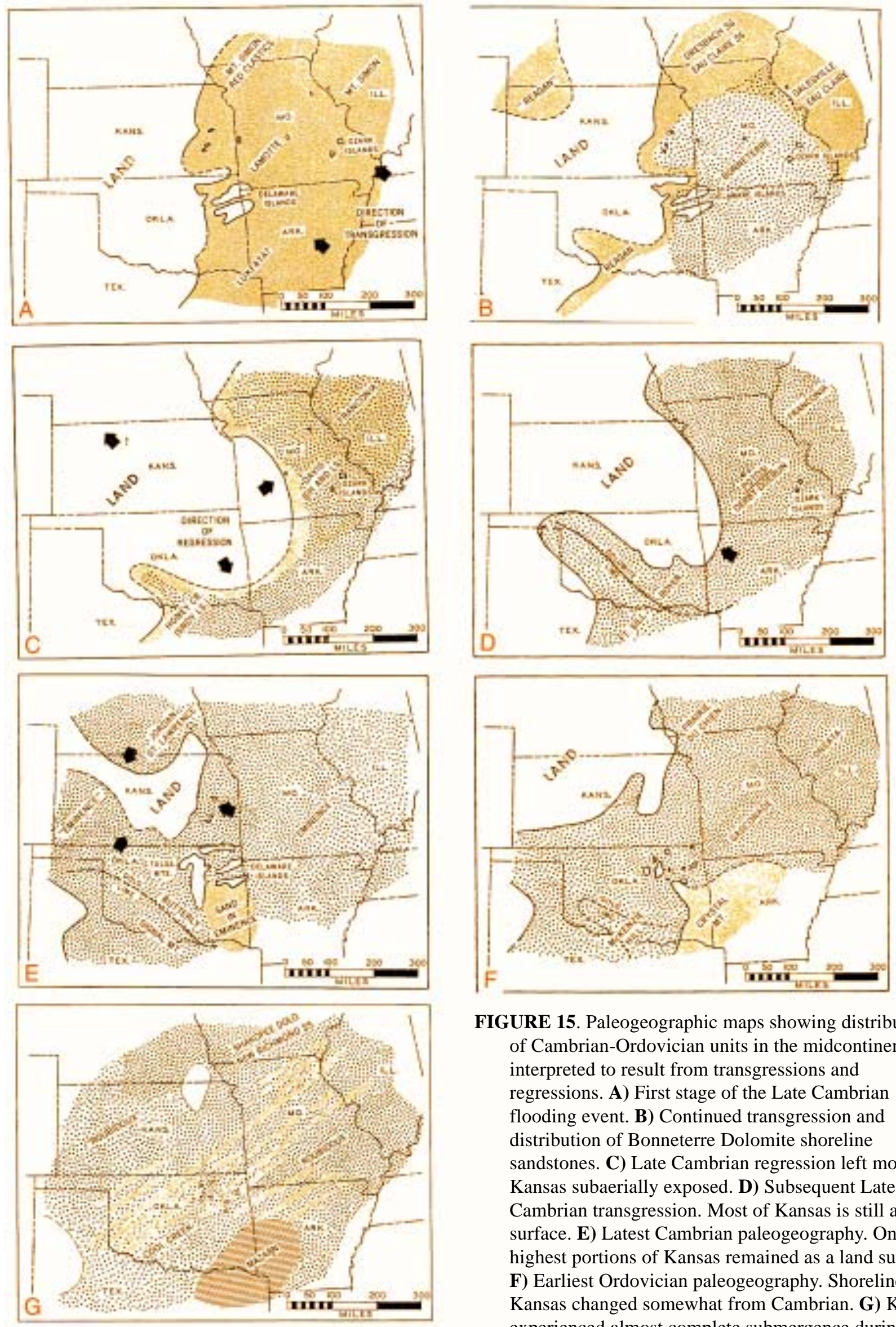

FIGURE 15. Paleogeographic maps showing distribution of Cambrian-Ordovician units in the midcontinent interpreted to result from transgressions and regressions. A) First stage of the Late Cambrian flooding event. B) Continued transgression and distribution of Bonneterre Dolomite shoreline sandstones. C) Late Cambrian regression left most of Kansas subaerially exposed. D) Subsequent Late Cambrian transgression. Most of Kansas is still a land surface. E) Latest Cambrian paleogeography. Only the highest portions of Kansas remained as a land surface. F) Earliest Ordovician paleogeography. Shorelines in Kansas changed somewhat from Cambrian. G) Kansas experienced almost complete submergence during Roubidoux deposition. From Chenoweth (1968). 


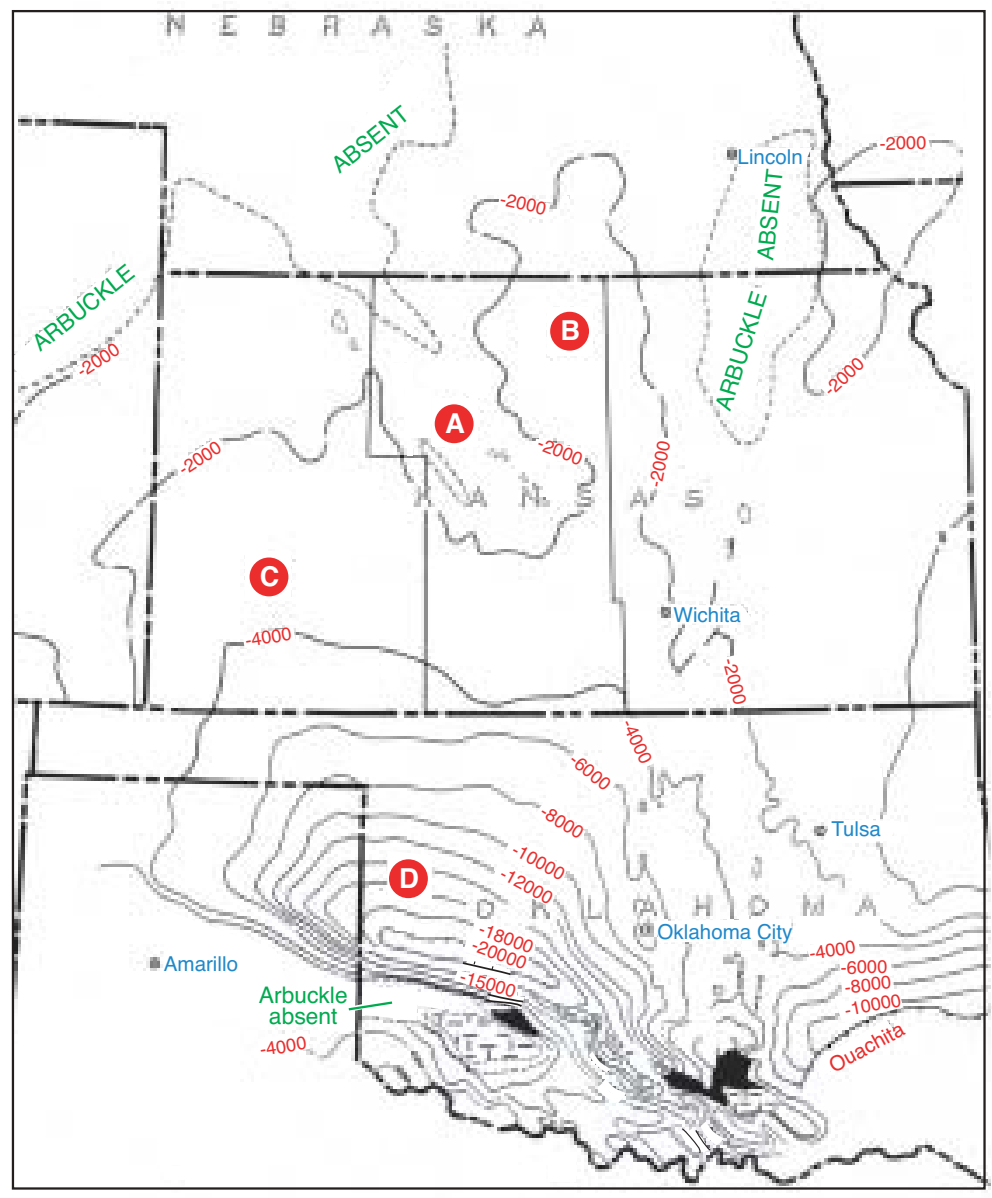

FIGURE 16. Regional structure map on top of Arbuckle Group. (A) Central Kansas uplift, (B) Salina basin, (C) Hugoton embayment of the Anadarko basin, (D) Anadarko basin. Contour interval 2,000 ft. From Bartram et al. (1950).

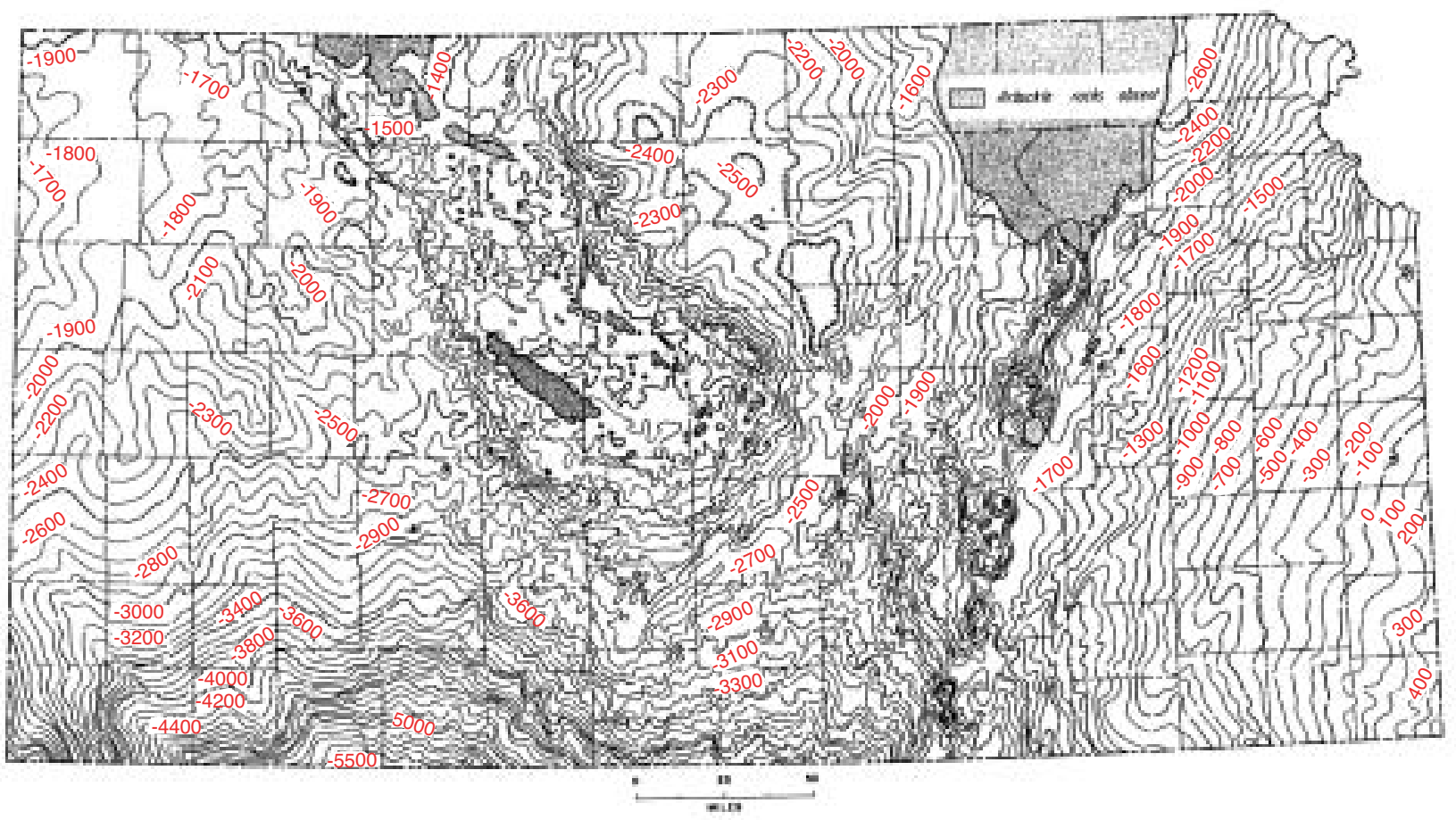

FIGURE 17. Preliminary regional structural map contoured on top of Arbuckle strata in Kansas. Contour interval 100 ft. From Merriam and Smith (1961). 

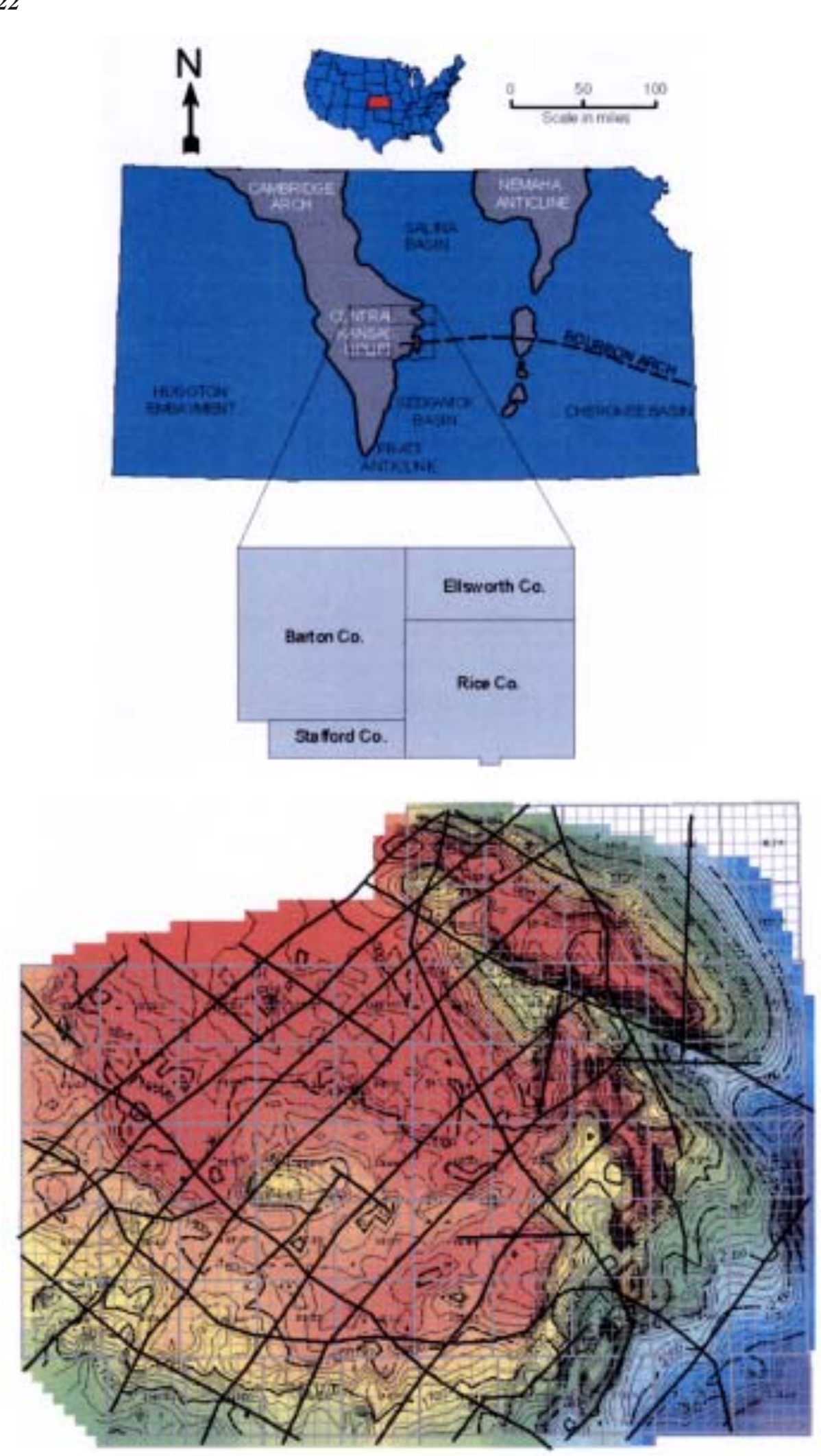

5 Mies

FIGURE 18. Location map and Arbuckle structure map. Interpreted lineaments from gravity and magnetics maps (dark lines) overlain on the Arbuckle structure map illustrate the general relationship of the erosional surface to basement structural elements. Structural elements in the Arbuckle of the Central Kansas uplift, such as regional uplifts and lineaments, and local uplifts and faults are represented on the Precambrian structure. Basement structure, when recognized, has a significant influence on alignment of karst and drainage features on the Arbuckle erosion surface. Contour interval $20 \mathrm{ft}$. From Cansler and Carr (2001). 


\section{Sedimentologic and Diagenetic Characteristics}

\section{Facies, Depositional Environments, and Cyclicity}

Arbuckle Group and equivalent-age rocks from outside of Kansas are described as platform deposits dominated by ramp-type subtidal to peritidal carbonates, which can be subdivided into cycles based on facies type and depositional patterns. Individual cycles (from less than $0.5 \mathrm{~m}$ to $40 \mathrm{~m}$ thick) in adjacent areas (e.g. Oklahoma, Arkansas) are numbered at between 350-450 (e.g. Wilson et al., 1991). These individual cycles recently have been shown to stack into cycle sets or bundles. These cycle sets in turn make up larger-scale depositional sequences that are bounded by regional and inter-regional sequence boundaries. The major sequence boundaries usually contain evidence of subaerial exposure, indicating relative sea-level falls.

Starting in the 1980's, researchers began describing in more detail the lithologic and diagenetic features of Arbuckle strata in Kansas. The results of these studies indicate that the Arbuckle strata in Kansas are very similar in character to Arbuckle and equivalent-age strata described in other localities. Conley (1980) studied thin sections from three Arbuckle cores on the CKU. Despite almost complete dolomitization, he identified primary Arbuckle depositional textures that range from mudstone to packstone and identified oolites, pellets, intraclasts, gastropods, echinoderms, bivalves, and stromatolites. He also recognized intercrystalline, fracture, moldic, fenestral, and interparticle porosity types that range from 1 to $22 \%$. Conley (1980) noted that porosity variability in part could be due to original depositional texture.

Dalal (1987) did a study on the characterization of the Arbuckle reservoir at the Lyons underground gas storage field in Rice County. Using insoluble residue data, he determined that the Arbuckle in the study location consists of Roubidoux Dolomite and undifferentiated Jefferson City Dolomite and Cotter Dolomite. Dalal (1987) observed that the reservoir consists of dolomitized stromatolite and silicified oolitic facies, which he used to interpret shallow subtidal (open-marine to lagoons permanently below low tides) environments for deposition. He also noted vertical variations in porosity and permeability, due to the tight silicified oolitic intervals alternating with permeable dolomitized stromatolitic intervals.

Ramondetta (1990) mentioned that Arbuckle strata in the El Dorado field (Nemaha uplift) are cyclic, upwardshoaling, and generally 10-20 ft thick. He noted that dolomudstones form the base of each cycle and grade upward to fossiliferous and oolitic grainstones up to $6 \mathrm{ft}$ thick. Ramondetta (1990) indicated $15-20 \%$ vuggy and intercrystalline porosities and over 100-md permeability in grainstones and local intercrystalline porosity in the predominantly tight dolomudstones.

Franseen $(1994,2000)$ documented the existence of subtidal to peritidal cycles in several cores located near the Central Kansas uplift. He noted that the facies appeared, at least locally, to be arranged in cyclic succession (likely shoaling-upward cycles) on the order of a meter to $5 \mathrm{~m}$ or more. Depositional facies in Arbuckle strata consist predominantly of coarse-grained skeletal, intraclastic, oolitic, peloidal, dolograinstones/packstones and finer-grained dolowackestones/mudstones, thrombolites and stromatolites, intraclastic conglomerate and breccia, and minor shale and siltstone. Silicified nodules and lenses are locally abundant and some may represent replacement of original evaporite minerals. Scoured, erosional surfaces occur within the Arbuckle with $\mathrm{mm}$-dm scale erosional relief. Intraclastic breccia and conglomerate commonly overlie these surfaces. Secondary features include dolomitization, breccia, fractures, and conglomerate related to intra-Arbuckle subaerial exposure, and breccia, fractures, and conglomerate related to later karst, burial or structural processes, silicification, and local mineralization (Franseen, 1994, 2000).

Steinhauff et al. (1998) documented subtidal and peritidal facies and the paragenetic sequence of events in 33 cores distributed across Kansas. They identified several scales of cycles (ranging from $<1 \mathrm{~m}$ to several meters) and cycle sets in cores and related cycles to electric log signatures for preliminary construction of an internal, high-resolution stratigraphic framework and correlation in the central Rice County, Kansas, study area (figs. 19, 20).

Development of stratigraphic and sequencestratigraphic frameworks and correlation of Arbuckle rocks remains a primary objective in Kansas and is crucial for providing frameworks for subsequent diagenetic and structural studies. Continued documentation of cycles and sets of cycles in the Arbuckle of Kansas could aid in correlations. Studies of Arbuckle and equivalent-age strata from other areas have shown the utility of cycle-stacking patterns within the context of sequence stratigraphy as an important tool in correlating Arbuckle strata and interpreting sea-level fluctuations and orbital-forcing mechanisms that were important during Arbuckle deposition (e.g. Kerans and Lucia, 1989; Wilson et al., 1991; Kupecz, 1992; Montanez, 1992; Goldhammer et al., 1993; Overstreet et al., 2003). Incorporating the everincreasing amount of modern well-log data that extend deeper into the Arbuckle with additional core data will be vital to establishing stratigraphic frameworks and correlation of Arbuckle strata. To date, no biostratigraphic data or chronostratigraphic correlations exist for the Arbuckle Group in Kansas. Conodonts (phosphatic microfossils that are found abundantly in marine rocks of Late Cambrian through Triassic age) have proven useful for stratigraphic subdivision and correlation of the 

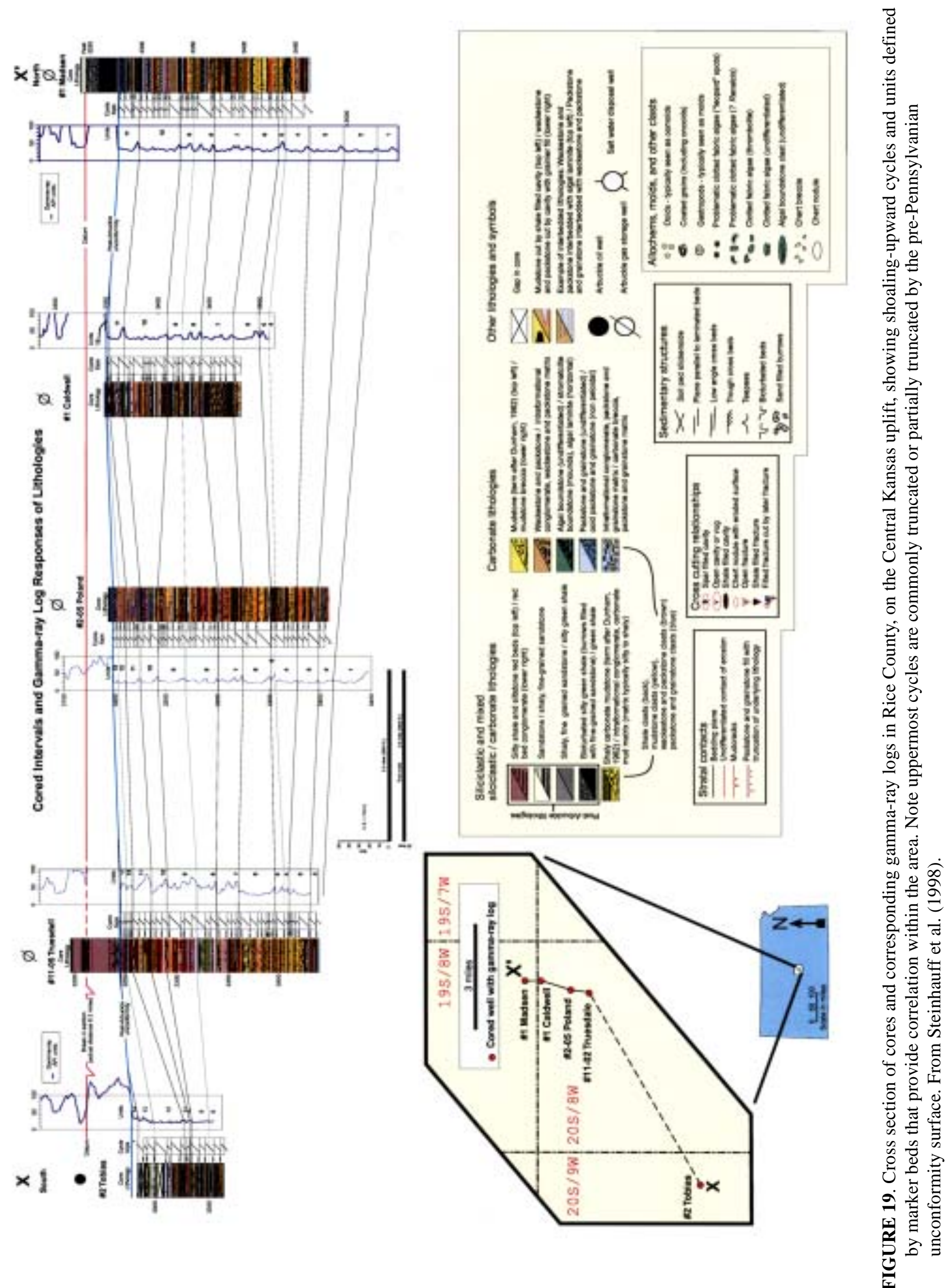


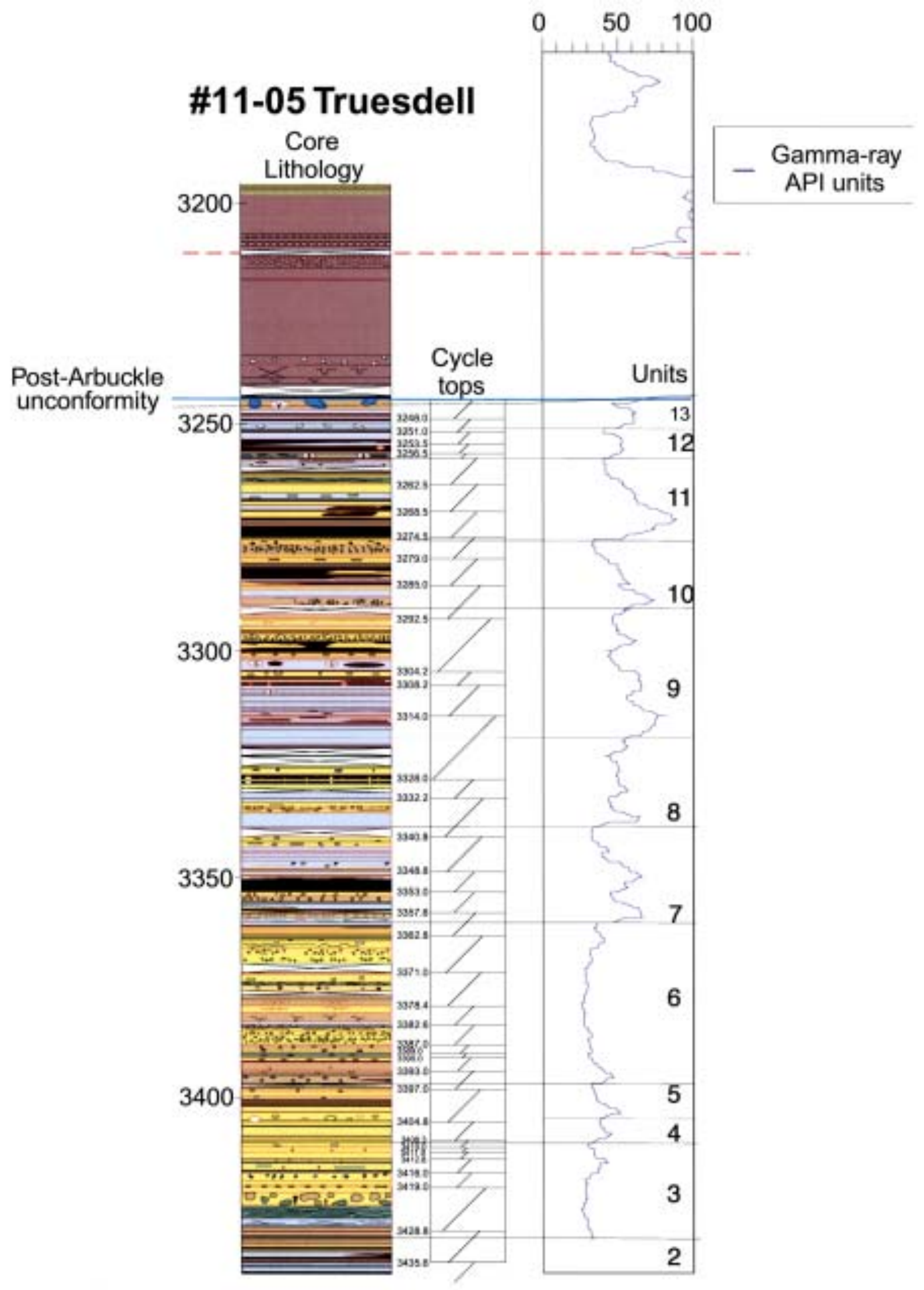

FIGURE 20. \#11-05 Truesdell core and corresponding gamma-ray log showing lithologic details of shoaling-upward cycles. See fig. 19 for lithologic details. From Steinhauff et al. (1998). 
uppermost Cambrian and throughout the entire Ordovician (Derby, Bauer, et al., 1991; Derby, Hinch, et al., 1991). Conodont studies could be useful in development of a chronostratigraphy for Arbuckle strata in Kansas, if more cores that extensively penetrate the entire Arbuckle Group become available.

Franseen (1994, 2000) and Steinhauff et al. (1998) identified facies that seem to be characteristic of Arbuckle strata in Kansas. Although Arbuckle rocks have been extensively dolomitized, much of the dolomitization is non-fabric destructive, thereby preserving original depositional facies textures. The 10 principal facies identified include (1) clotted algal boundstone, (2) laminated algal boundstone, (3) peloidal packstonegrainstone, (4) mixed packstone-grainstone, (5) ooid packstone-grainstone, (6) wackestone-mudstone, (7) intraclastic conglomerate and breccia, (8) cave fill shale, (9) depositional shale, and (10) chert. The first six lithologies listed account for more than $85 \%$ of the cored intervals described and the rest account for the remaining $15 \%$. The facies descriptions from those studies are the most detailed published facies descriptions for Kansas Arbuckle rocks to date, and are repeated below.

\section{Clotted Algal Boundstone}

This facies consists of muddy, peloid-rich mottled (thrombolitic) to wavy-laminated clotted algal-carbonate lithology (fig. 21A). Other clotted forms (? Renalcis) are also present. Thrombolite-leopard rock texture is typically muddy with some grains. Local burrow mottling is present. Thrombolitic and clotted boundstones have a tightly bound matrix consisting of anhedral, euhedral, and polyhedral dolomite $(<0.5 \mathrm{~mm})$ with peloidal cement. Thrombolitic boundstones typically have excellent sheetlike vuggy and fenestral porosity and poor intercrystalline porosity. Most thrombolitic boundstones were probably deposited in subtidal environments.

\section{Laminated Algal Boundstone}

This facies consists of wavy-laminated algal boundstones and stromatolites with muddy (fig. 21B) to grainy textures (fig. 21C). Current-modified (ripple) lamination occurs locally. Brecciated stromatolite facies typically grades upward to non-brecciated, in-place stromatolites. The stromatolites are locally tightly cemented but commonly contain abundant and distinctive differentially developed intercrystalline, fenestral, keystone-vug, and solution-enlarged porosity that closely follows laminations. This facies likely represents subtidal to peritidal (where fenestrae are present) environments. This facies is locally oil stained.

\section{Peloidal Packstone-Grainstone}

This facies is typically massive, horizontally laminated or bedded (fig. 21D), and commonly interbedded with coarser-grained lithologies. Locally, it contains wispy lenses of shale and interbedded shale layers. Burrow traces and mottling are common. Peloids are abundant and rare interclasts, lumps, and skeletal grains (gastropods) are present. Soft-sediment deformation, dewatering or tepee-like structures, mudcracks, and rip-up clasts are locally associated with this facies. The mud-rich peloidal packstone/grainstone facies represents deposition in relatively lower-energy

FIGURE 21 (following page). Core photographs of major Arbuckle facies. Note the width of cores in each photo is approximately 3.5 inches. A) Clotted Algal Boundstone. This facies consists of muddy, peloid-rich mottled (thrombolitic) to wavy-laminated clotted algal carbonate lithology. Porosities are generally less than $6 \%$ and permeabilities are below 0.1md. B) Laminated Algal Boundstone (muddy). This facies consists of wavy-laminated algal boundstones and stromatolites. Porosities are generally less than $6 \%$ and permeabilities are below $0.1 \mathrm{md}$. C) Laminated Algal Boundstone (grainy). This facies consists of wavy-laminated algal boundstones and stromatolites, and represents some of the best reservoir rock with porosity up to $32 \%$ and permeability up to $1,500 \mathrm{md}$. D) Peloidal Packstone-Grainstone. This facies is typically massive, horizontally laminated, or bedded. Porosities range from $0 \%$ to $4 \%$, and absolute permeabilities range from $0.0003 \mathrm{md}$ to $0.1 \mathrm{md}$ but are generally below $0.005 \mathrm{md}$. E) Packstone-Grainstone. This facies is typically massive, horizontally bedded, or crossbedded. Porosities range from $6 \%$ to $18 \%$, and permeabilities range from $0.1 \mathrm{md}$ to $50 \mathrm{md}$. F) Ooid Packstone-Grainstone. This facies is typically massive, horizontally bedded, or crossbedded. Porosities range from $11 \%$ to $30 \%$, and permeabilities range from $10 \mathrm{md}$ to $1,500 \mathrm{md}$. G) Wackestone. This facies is typically massive to horizontally laminated. Porosities range from $2 \%$ to $11 \%$, and permeabilities range from $0.01 \mathrm{md}$ to $1 \mathrm{md}$. $\mathbf{H}$ ) Mudstone. This facies is typically massive to horizontally laminated. Porosities range from $0 \%$ to $10 \%$, and absolute permeabilities range from $<0.0001 \mathrm{md}$ to $0.1 \mathrm{md}$. I) Intra-Arbuckle Shale. Some shales are interbedded with carbonate rocks suggesting they were deposited during Arbuckle deposition. Shales are tight and represent permeability barriers. J) Breccia. Brecciation and fracturing occur with various textures. This example shows chaotically oriented clasts of various lithologies. Breccia facies typically have variable porosities and permeabilities that are primarily a function of the lithologies that were brecciated. K) Fracture-fill Shale. Much of the shale is green and clearly present as fracture or cave fill, with sediment originating from above the upper Arbuckle unconformity surface. This shale occludes original fracture porosity. L) Chert. Chert (white area) locally occurs as a replacement of carbonate facies. Chert replacement commonly results in tight and impermeable areas. 

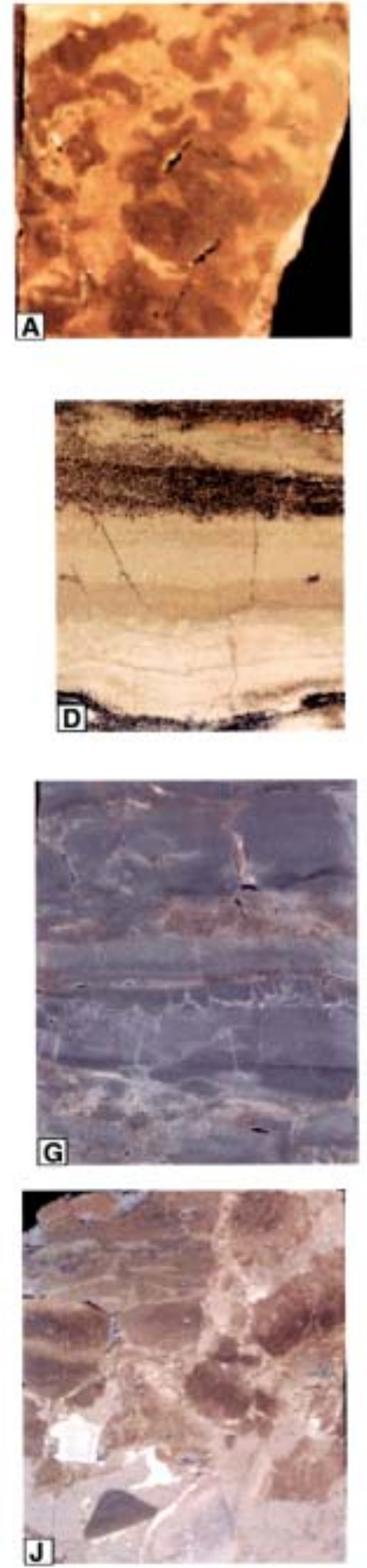
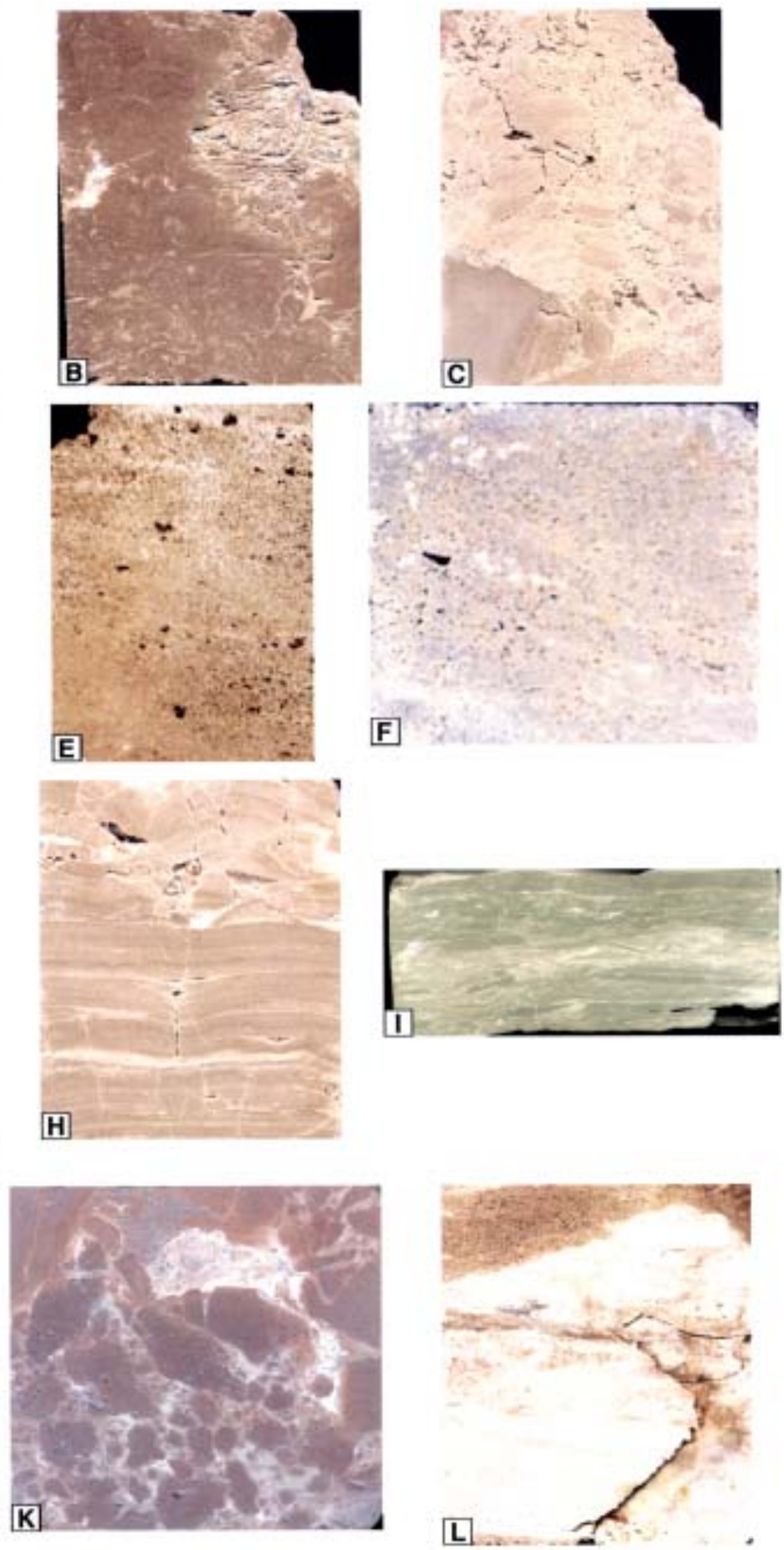
subtidal (massive to burrowed textures) and peritidal (mudcracks, tepees, and rip-up layers and clasts) settings. This rock is tightly bound, consisting of anhedral, euhedral, and polyhedral dolomite $(<0.5 \mathrm{~mm})$ and peloidal cement.

\section{Mixed Packstone-Grainstone}

This facies is typically massive, horizontally bedded or crossbedded (fig. 21E), and typically interbedded with ooid packstone-grainstone and wackestone-packstone facies. Grains include intraclasts, skeletal and algal fragments, ooids, peloids, and lumps. This facies indicates higher energy deposition in subtidal to peritidal (fenestrae and keystone vugs) settings. Locally, packstonegrainstone is tightly cemented by euhedral dolomite ( $\leq$ $0.5 \mathrm{~mm}$ ). However, this facies typically has good intercrystalline porosity. In some rocks the original cement between grains has been leached, creating interparticle porosity that is open or filled with chert. The chert has a "chalky" appearance and is porous but exhibits low permeability.

\section{Ooid Packstone-Grainstone}

This facies (fig. 21F) is typically massive, horizontally bedded or crossbedded, and typically interbedded with wackestone-packstone facies. Dominant grains are ooids, but other grains including intraclasts, skeletal and algal fragments, peloids, and lumps occur in varying abundance. This facies indicates higher energy deposition in subtidal to peritidal (fenestrae and keystone vugs) settings. This facies typically has good intercrystalline porosity, but locally is tightly cemented by euhedral dolomite (< to $0.5 \mathrm{~mm}$ ). In some rocks the original cement between grains has been leached creating interparticle porosity that is open or filled with chert. This chert has a "chalky" appearance and is porous but exhibits low permeability.

\section{Wackestone-Mudstone}

This facies is typically massive to horizontally laminated (figs. $21 \mathrm{G}, 21 \mathrm{H}$ ). Burrow mottling is typically present in most intervals. This facies typically is composed of euhedral dolomite $(<0.05 \mathrm{~mm})$ with little or no porosity. Replacement of evaporite nodules with chert is observed locally. This facies is interpreted as being deposited in shallow-water, low-energy restricted environments.

\section{Intra-Arbuckle Shale}

Some shales are interbedded with carbonate rocks suggesting they were deposited during Arbuckle deposition (fig. 21I). In addition, horizons with wavyhorizontal to horizontally interbedded shale and carbonate mudstone-wackestone are present. Several shale layers contain silicified nodules and lenses that may have replaced evaporites. These shale layers likely represent relatively low-energy subtidal to peritidal conditions. Supratidal conditions may be indicated for some horizons where silicified nodules apparently represent replacement of original evaporite minerals.

\section{Conglomerate and Breccia}

Many conglomerates or breccias consist of rip-up clasts derived from underlying lithologies. Textures range from clast- to matrix-supported. Conglomerates and breccias are commonly associated with desiccation and mud cracks, dewatering structures, and tepees. Local autoclastic breccia textures indicate subaerial exposure of some Arbuckle horizons. Some collapse breccia may have resulted from the dissolution of evaporites. These conglomerates evidence intra-Arbuckle high-energy erosional and subaerial exposure events in subtidal to peritidal settings. The conglomerate and breccia facies typically have variable porosities and permeabilities that are primarily a function of the lithologies that were brecciated. Later brecciation and fracturing occurs with various textures ranging from incipient fracturing and brecciation with a fitted clast texture to extreme brecciation with chaotically oriented clasts of various lithologies (fig. 21J). The features are consistent with a karst origin from exposure at the post-Sauk unconformity. These late-stage breccias and fractures are variably open to tight.

\section{Fracture-fill Shale}

Much of the shale is green and clearly present as fracture (fig. $21 \mathrm{~K}$ ) or cave fill, with sediment originating from above the upper Arbuckle unconformity surface. Locally, fracture fills contain fragments of dolomite rhombs and subangular to rounded silt-size to coarsegrained detrital quartz grains.

\section{Chert}

Chert commonly occurs as a replacement of carbonate facies (typically preserving original textures) and, locally, original evaporite minerals. Chert replacement commonly results in tight and impermeable areas (fig. 21L). Locally, where only partial replacement occurs, some vuggy and intercrystalline porosity is developed.

\section{Diagenetic Features and Porosity Types}

Franseen (1994, 2000) and Steinhauff et al. (1998) noted the following general paragenetic sequence of events listed from oldest to youngest: (1) deposition of original facies including intraformational erosion and subaerial exposure events as indicated by autobrecciation, mudcracks, fenestrae, and rip-up conglomerates; (2) early dolomitization evidenced by silicified dolomite rhombs in chert clasts that occur in later fractures; (3) silicification, as indicated by displacive growth textures of silica areas 
in dolomite, differential compaction between silica (brittle fracturing) and surrounding dolomite matrix (softsediment deformation), and silicified carbonate grains and facies occurring as clasts (with truncated grains at clast boundaries) occurring in later fractured and brecciated areas; (4) subaerial exposure and karstification producing the post-Sauk unconformity; open, partially occluded, or fully occluded fractures and breccia fabrics; and dissolution that cut across all previous events; and (5) burial. Associated features include later dolomitization(s), including some baroque dolomite, mineralization, compaction, and fracturing that cuts across all previous features.

These secondary features significantly affected the original depositional facies. However, although the dolomitization is pervasive, in cores studied to date it is mostly non-fabric destructive. Later brecciation and fracturing occur with various textures, ranging from incipient fracturing and brecciation with a "fitted" clast texture and little clast rotation to extreme fracturing and brecciation with chaotically oriented clasts of various lithologies. This later-stage fracturing and brecciation also is characterized by various types of sediment fill and locally by cements. Many of these late-stage fractures are only partially filled, or in some cases completely open, and represent significant effective secondary porosity. Some of these features are similar to those described by Kerans (1988) in the Ellenburger that he attributed to karsting associated with the pre-Simpson Group (Middle Ordovician) subaerial exposure event. Several horizons in the cores studied by Franseen $(1994,2000)$ and Steinhauff et al. (1998) show an upward transition of chaotic clastsupported or matrix-supported breccia texture to a fitted, fracture breccia texture with little to no clast rotation, which may represent a transition from cave-collapse zone upward to cave-roof facies possibly developed during the post-Sauk subaerial exposure event. Elsewhere, fractures appear to have preferred orientations that likely reflect a tectonic influence. In addition to the open fractures, other late-stage porosity development includes vuggy, channel, and interparticle porosity, much of which is likely related to the post-Arbuckle exposure event.

Franseen $(1994,2000)$ and Steinhauff et al. (1998) noted that the striking feature in many cores is the abundance and apparent importance of "matrix" porosity (intercrystalline, moldic, fenestral, vuggy) throughout the entire lengths of the cores, which is related to depositional facies, early diagenesis, and dolomitization and not necessarily related to the upper post-Sauk subaerial exposure surface. Their initial observations indicate that more than $50 \%$ of the preserved porosity are these types of "matrix" porosity. Much of the matrix porosity-rich intervals are associated with coarse-grained, laminated to bedded facies that are differentially cemented or with stromatolitic intervals that show differential porosity development likely due to differences in original texture (e.g. mud content) and early diagenesis (e.g. development of fenestral and vuggy porosity during early subaerialexposure events).

\section{Core-Scale Petrophysical Trends}

Byrnes et al. (1999) collected petrophysical data from a number of core-plug samples of the different Arbuckle facies described above. That study emphasized the important contribution of original facies character and matrix properties to reservoir character (fig. 22). The following is a summary of petrophysical properties from Byrnes et al. (1999).

Peloidal Packstone-Grainstone: Cementation of matrix has resulted in nearly total occlusion of porosity. Porosities range from $0 \%$ to $4 \%$ and absolute permeabilities range from $0.0003 \mathrm{md}$ to $0.1 \mathrm{md}$ but are generally below $0.005 \mathrm{md}$. Fenestrae within this facies may range up to several centimeters in length and may enhance porosity by several percent. Fenestrae in this lithology are not interconnected but are isolated by lowpermeability matrix.

Mudstone: Without fractures or fenestrae, these exhibit porosities ranging from zero to $10 \%$ and absolute permeabilities ranging from $<0.0001 \mathrm{md}$ to $0.1 \mathrm{md}$. Where fenestrae are present, porosity may be enhanced up to values as high as $17 \%$; however, the fenestrae are primarily isolated and permeabilities are not increased significantly.

Wackestone: Without vugs these exhibit porosities ranging from $2 \%$ to $11 \%$ and permeabilities ranging from $0.01 \mathrm{md}$ to $1 \mathrm{md}$. Where vugs are present, porosities can range from $9 \%$ to $17 \%$, and permeabilities can range from $1 \mathrm{md}$ to $1,000 \mathrm{md}$.

Packstone: Porosities range from 6\%, for finer-grained rock and where packstone is mottled with wackestone, to $18 \%$ for cleaner more coarse-grained rock. Permeabilities in the packstone lithology range from $0.1 \mathrm{md}$ to $50 \mathrm{md}$.

Ooid Packstone-Grainstone: Generally these contain little to no vuggy porosity but exhibit intercrystalline and moldic porosities ranging from $11 \%$ to $30 \%$; associated permeabilities range from $10 \mathrm{md}$ to $1,500 \mathrm{md}$. The highest porosity and permeability values are exhibited by clean, homogeneous, medium-grained moldic packstones.

\section{Muddy Clotted and Laminated Algal Boundstones:} Laminated muddy algal boundstones exhibit porosities generally less than $6 \%$ and permeabilities below $0.1 \mathrm{md}$. Where fenestral or vuggy porosity is developed, these may exhibit high permeability at the core-scale, but it is unlikely that these high permeabilities are laterally pervasive at the interwell scale. 


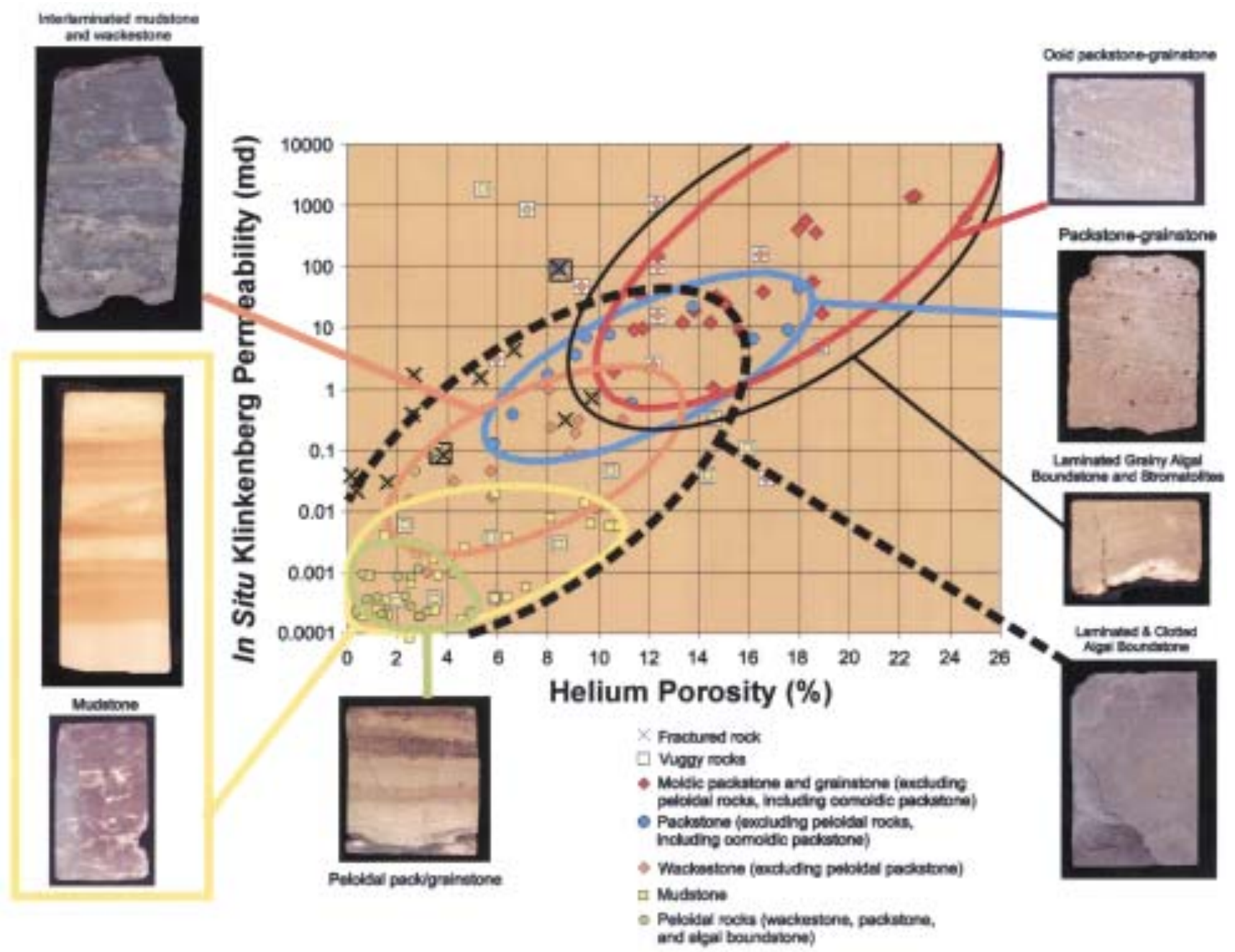

FIGURE 22. Core-plug petrophysics. Petrophysical properties of the facies at the core-plug scale are generally controlled by matrix grain size. Each lithology exhibits a generally unique range of petrophysical properties. All lithologies exhibit increasing permeability with increasing porosity and can be characterized as lying along the same general porosity permeability trend. Note that fracturing of lithologies enhances permeability but does not add significantly to porosity. Vuggy pores can be well connected where vuggy porosity is extensive near the unconformity surface.

Laminated Grainy Algal Boundstones: Laminated grainy algal boundstones represent some of the best reservoir rock ranging in porosity up to $32 \%$ and permeability up to $1,500 \mathrm{md}$.

\section{ECONOMIC ASPECTS}

\section{Hydrocarbons}

Since the 1910's, several billion barrels of oil have been produced from the Central Kansas uplift (CKU), primarily from carbonate reservoirs within the Arbuckle and Lansing-Kansas City (Pennsylvanian) Groups. The Arbuckle fields of central Kansas followed closely on the heels of the Arbuckle discovery in 1917 at El Dorado field in Butler County, Kansas, and these Arbuckle fields represent the first oil production in the western ranges of Kansas. The majority of these Arbuckle reservoirs of central Kansas were drilled prior to 1955 and constitute a series of giant and near-giant oil fields (fig. 23). The significance of the Arbuckle to Kansas production and reserves is highlighted by the estimate that Arbuckle reservoirs have produced about 2.19 billion barrels of oil (BBO) representing approximately $36 \%$ of the $6.1 \mathrm{BBO}$ of total Kansas oil production to date (fig. 24).

Structure has played a major role in the development of Arbuckle reservoirs on several different scales. On a statewide scale, most major hydrocarbon production within the Arbuckle in Kansas occurs on two major uplift features, the CKU and the Nemaha uplift (fig. 25), with 
the Arbuckle Group being the most significant pay zone on the CKU (Newell et al., 1987). Most productive fields on the CKU are structural and structural-stratigraphic traps that produce oil or gas from the top of the Arbuckle section (Walters, 1958). On a more local scale, the El Dorado field in Butler County is associated with several large-scale fault-bounded domes. As an example of structural influence on a still smaller scale, high-volume production within the West Shumway dome in the El Dorado field follows what appear to be original tectonic fracture systems with north-south and east-west orientations (Ramondetta, 1990).

Arbuckle reservoirs produce from 31 counties statewide with a significant portion of the total production coming from the 10 counties in the CKU region (fig. 25). Within the 10-county area on the CKU, the Arbuckle has produced over 1,630 MBO, representing $69 \%$ of the production from the top four producing intervals in this region (fig. 26). Table 1 lists the 21 most productive Arbuckle fields and the cumulative oil production attributed to each. These fields represent approximately $56 \%$ of all Arbuckle production with 19 of the fields lying on the CKU and the remaining two on the Nemaha uplift in Butler and Cowley counties.

Arbuckle reservoirs historically have been viewed as fracture-controlled karstic reservoirs with porosity and permeability influenced by basement structural patterns and subaerial exposure. The weathering and secondary solution of the upper Arbuckle beds, due to subaerial exposure, are thought to have significantly enhanced porosity and permeability and created petroleum reservoirs in these strata (Walters, 1958; Merriam, 1963; Adler, 1971).

Most of the oil and gas zones in the Arbuckle are contained in the top $25 \mathrm{ft}$, some are $25-50 \mathrm{ft}$ within the Arbuckle (Adler, 1971), and Arbuckle wells are characterized by high initial potential, steep decline rates, and production of large quantities of oil at high water/oil ratios. Thus, Arbuckle reservoirs typically have been visualized as an oil column on top of a strong aquifer. This conceptual model of the Arbuckle reservoir resulted in drilling and completion practices in which wells were drilled into the top of the Arbuckle with relatively shallow penetration (under $10 \mathrm{ft}$ or $3 \mathrm{~m}$ ) and completed open hole.

Although the Arbuckle has been a prolific producing interval since 1917 , annual production peaked in the early 1950's at more than 68 million barrels and has declined to approximately 12 million barrels per year in 2002 (fig. 27). Today, stripper production dominates Arbuckle production with over $90 \%$ of wells producing less than 5 barrels of oil per day and is very sensitive to commodity prices.

\section{Arbuckle Fields in Kansas}

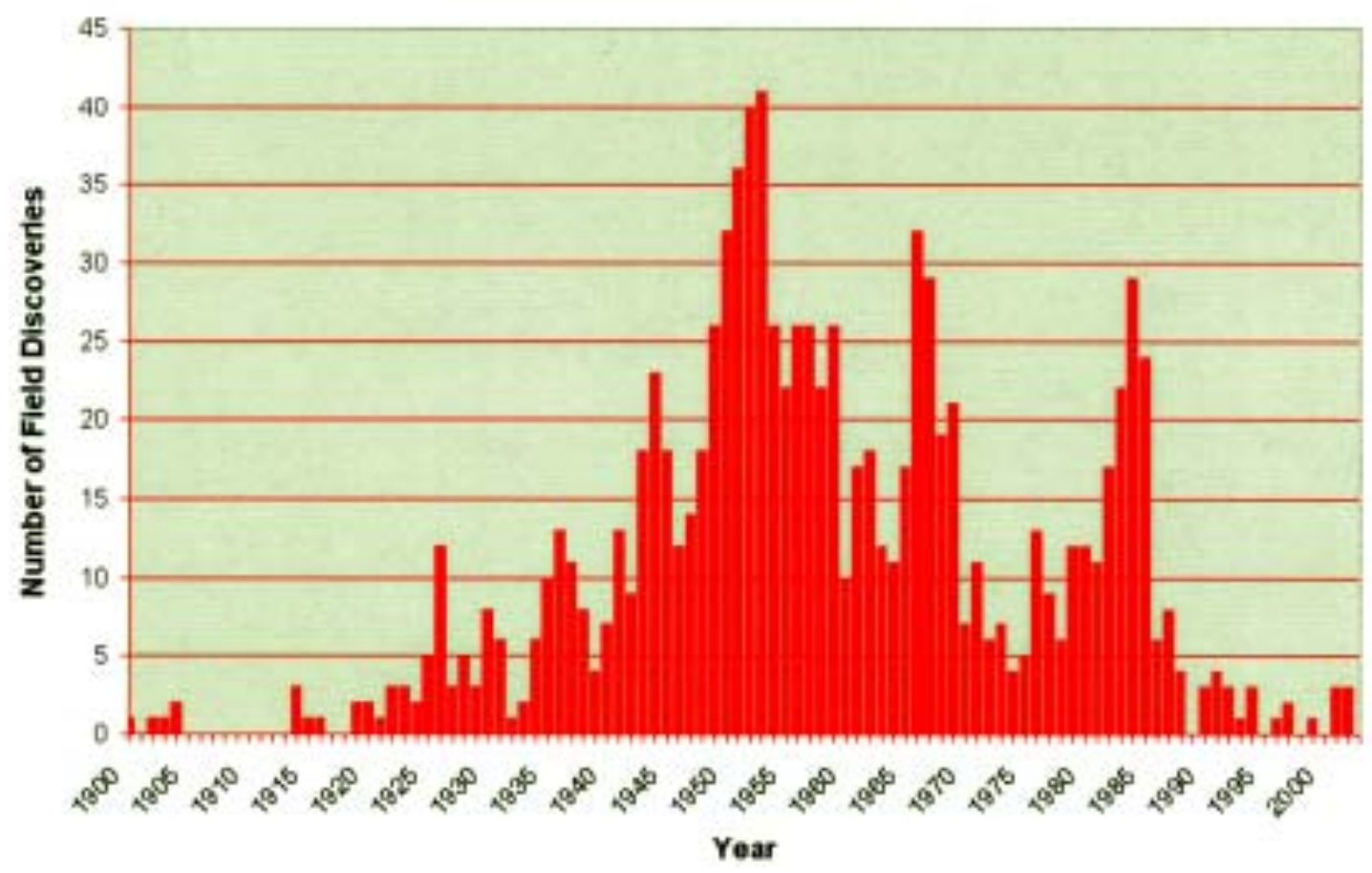

FIGURE 23. Plot of number of Arbuckle field discoveries by year. Almost $50 \%$ of Arbuckle fields were discovered by 1955, which closely coincides with the peak year of discovery (1953). Subsequent secondary discovery peaks occurred in the late 1960's and mid-1980's and can be attributed to new technology and commodity prices. 


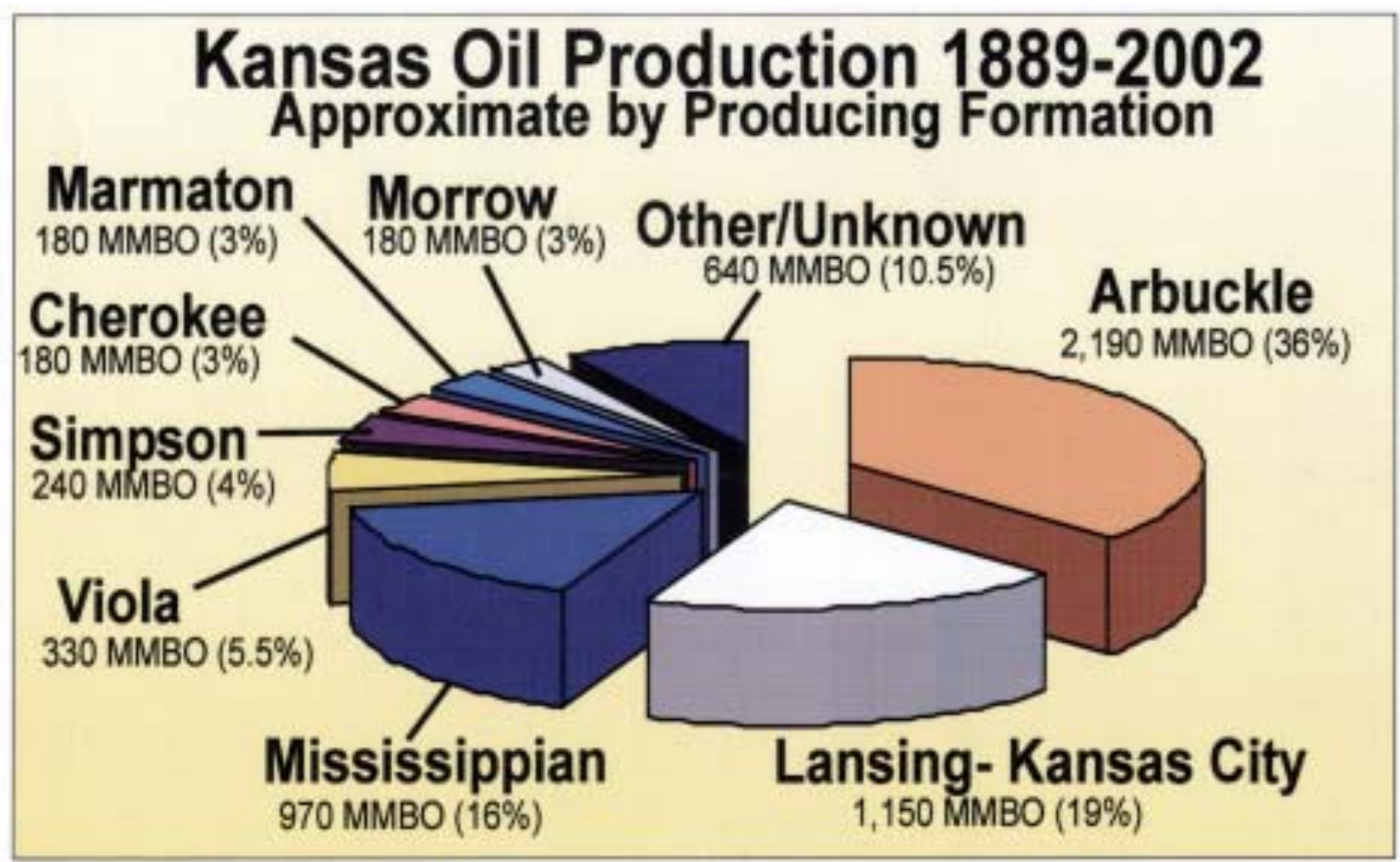

FIGURE 24. Arbuckle reservoirs have produced 2.19 billion barrels of oil (BBO) representing $36 \%$ of the $6.1 \mathrm{BBO}$ of total Kansas oil production.

\section{Recent and Ongoing Research Related to Arbuckle Group Reservoirs}

Some recent and ongoing studies on various geologic aspects of the Arbuckle Group in Kansas are beginning to provide a clearer picture of the different types of Arbuckle reservoirs, which is becoming increasingly important because the Arbuckle is currently undergoing improved oil recovery (IOR) efforts, and being considered for future $\mathrm{CO}_{2}$ floods and carbon sequestration.

The striking feature in many cores studied by Franseen $(1994,2000)$ and Steinhauff et al. (1998) is the abundance and apparent importance of "matrix" porosity (intercrystalline, moldic, fenestral, vuggy) throughout the entire lengths of the cores, which is related to depositional facies, early diagenesis, and dolomitization and not necessarily related to the upper post-Sauk subaerial exposure surface. The relative lack of karst-associated fracture, breccia, and dissolution porosity in most cores is especially surprising considering that the cores came from flanks or tops of structural highs where karst processes would likely have been most extensive. Observations indicate that more than $50 \%$ of the preserved porosity is "matrix" porosity. Much of the matrix porosity-rich intervals are associated with coarse-grained, laminated to bedded facies that are differentially cemented or with stromatolitic intervals that show differential porosity development likely due to differences in original texture (e.g. mud content) and early diagenesis (e.g. development of fenestral and vuggy porosity during early subaerial exposure events).

Byrnes et al. (1999) showed that the petrophysics of Arbuckle lithofacies at the core-plug scale, and for many lithologies at the whole-core scale, are dominantly controlled by grain size. Each lithology exhibits a generally unique range of petrophysical properties modified by the presence of fractures, vuggy porosity, and grain-size variation within the lithologic class. Facies comprising multiple lithologies of differing grain size exhibit bulk properties that are scale-dependent and are a function of the architecture of the constituent facies. All lithologies exhibit increasing permeability with increasing porosity and can be broadly characterized as lying along the same general porosity-permeability trend (fig. 22). Variance in permeability for any given porosity is approximately two orders of magnitude and may be primarily attributed to the influence of such lithologic variables as the ratio and distribution of matrix and fenestral/vuggy porosity, grain-size variations, and subtle mixing or interlamination of lithologies. Fracturing of lithologies enhances permeability directionally but does not add significantly to porosity (fig. 22). Vuggy porosity (even up to as high as $8 \%$ ) is largely isolated in 


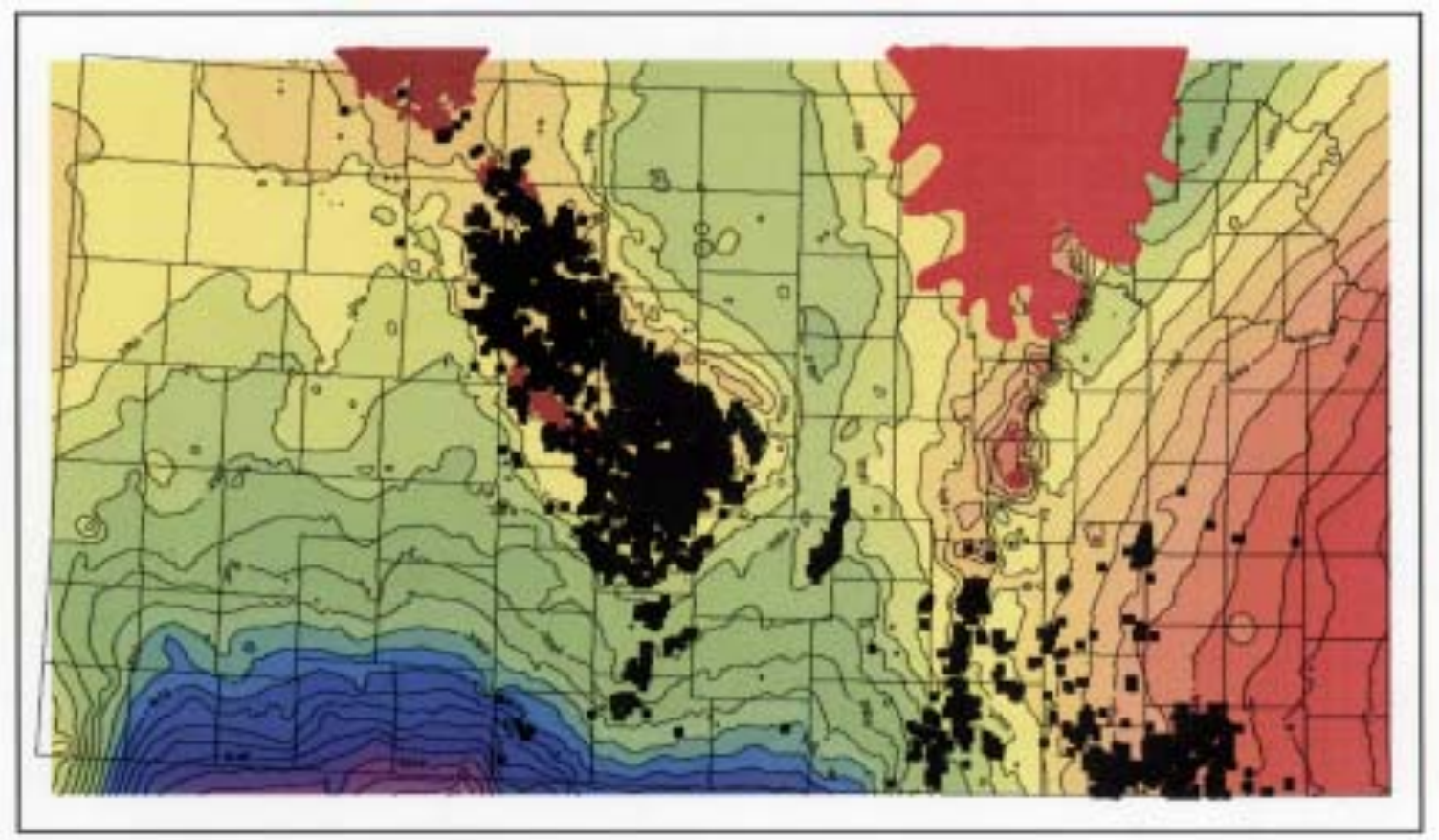

A

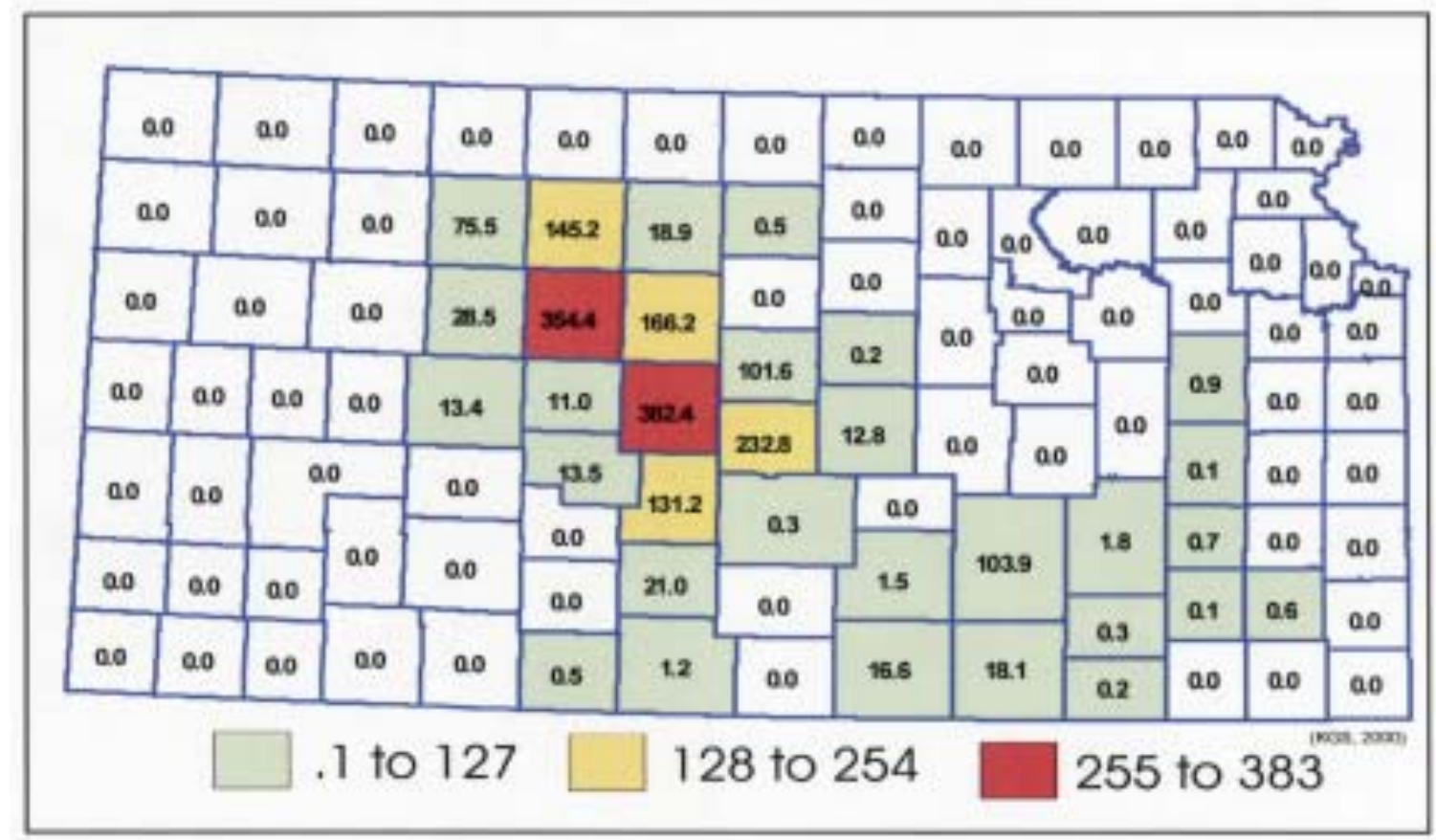

B

FIGURE 25. A) Structure map (subsea elevation) on Arbuckle showing locations of Arbuckle production in Kansas (black). Note most production is associated with structural highs, especially the Central Kansas uplift (CKU), with other major areas of production coming from the Nemaha uplift and in the southeast. B) Arbuckle cumulative oil production (MMBO) by county. Of the 31 counties in which the Arbuckle has been productive, over $70 \%$ of the production has come from the 10-county area coinciding with the CKU. 


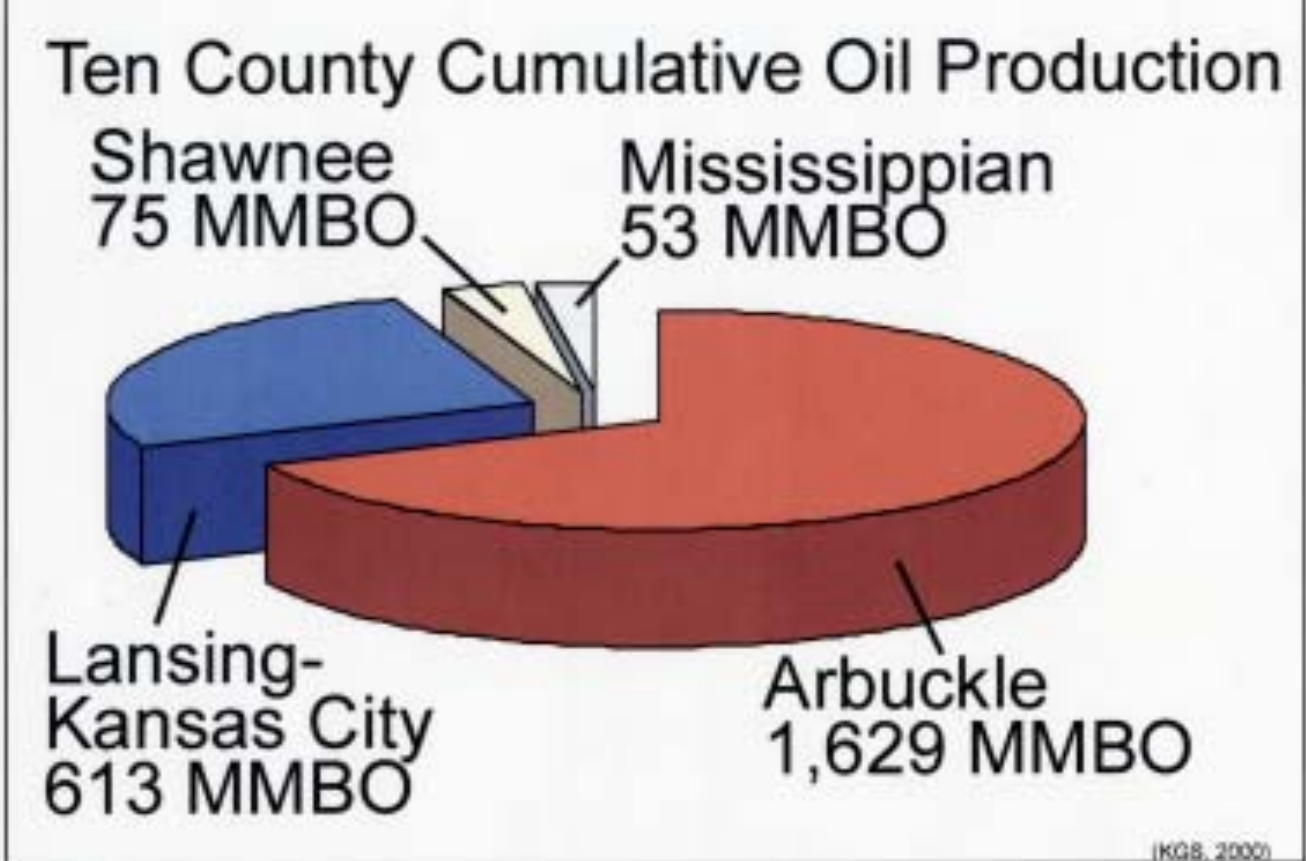

FIGURE 26. The Arbuckle has produced over 1,629 MBO in the 10-county area on the Central Kansas uplift, which represents $69 \%$ of the production from the top four producing intervals in this region.

mudstones, but is better connected in wackestones. Vuggy pores can be well connected where vuggy porosity is extensive near the unconformity surface.

The dominance of matrix porosity (intercrystalline, moldic, fenestral, vuggy) related to depositional facies, early diagenesis, and dolomitization, and the control of laterally persistent stratal packages on flow properties is a departure from the perception that karst is the only control on reservoir properties, and emphasizes the importance of understanding facies distribution. For example, the packstone-grainstone and boundstone reservoir facies are much more likely to be favorable reservoirs where they intersect the unconformity as compared to where other non-reservoir facies intersect the unconformity (Franseen et al., 2003). In addition, the facies distributions in potentially laterally continuous beds of various scales may have implications for deeper reservoir zones. Deeper lowto moderate-volume stratified production has been identified in a number of fields in Kansas (e.g. Ramondetta, 1990; Mullins and Ireland, 1967).

Much more diagenetic study, especially on dolomitization and karst processes, is needed to understand their environments, relative timing, and effects on reservoir character. Dolomite is important in both the development and destruction of porosity within the Arbuckle Group. Dolomitization may either predate or postdate various events of fracture formation. In many areas, intercrystalline and moldic porosity is dominant within reservoir lithologies. Distribution of this porosity appears to be limited to certain stratigraphic horizons and certain lithofacies, some resulting in nonporous dolomite and others resulting in porous and permeable dolomites. Furthermore, one or more later phases of dolomitization seem to have significantly affected porosity and permeability in places. The occlusion or creation of porosity associated with this late dolomitization may be related to migration of post-Arbuckle fluids, including hydrothermal fluids and hydrocarbons, that seek appropriate conduits for flow. Further structural and paleohydrogeologic studies are needed to understand the distribution of late-stage dolomite and its effect on reservoir character.

Our understanding of the structural setting and potential structural elements that could have affected Arbuckle strata in any given location is aided by existing regional maps of basement rocks (e.g. Baars and Watney, 1991; Berendsen and Blair, 1992), Arbuckle rocks (Merriam and Smith, 1961), and gravity and magnetic pattern maps (Kruger, 1996). However, more detailed regional and local (field-scale) data and maps are needed to understand distribution and nature of structural elements, including fractures and faults, as they may be quite variable, which can impact reservoir character.

Whereas the Arbuckle is below hydrostaticequilibrium pressure in Kansas $(0.433 \mathrm{psi} / \mathrm{ft})$, final shut-in pressures for thousands of Arbuckle wells exhibit a wide distribution, with a significant number exhibiting pressures less than half the regional hydrostatic pressure (Franseen et al., 2003; fig. 28). Although some low pressures result from poor reservoir permeability and lack of complete DST equilibration, initial and ongoing production from the reservoirs tested supports the 
TABLE 1. Twenty-one major Arbuckle fields.

\begin{tabular}{|c|c|c|c|c|c|}
\hline $\begin{array}{l}\text { Field } \\
\text { Name }\end{array}$ & $\begin{array}{c}\text { Cumulative } \\
\text { Oil } \\
\text { (bbl) }\end{array}$ & $\begin{array}{l}\text { Active } \\
\text { Wells }\end{array}$ & $\begin{array}{l}\text { Twn } \\
\text { Rng }\end{array}$ & County & $\begin{array}{l}\text { Approx. } \\
\text { Depth } \\
\text { (ft) }\end{array}$ \\
\hline CHASE-SILICA & $307,571,872$ & 876 & 18S-10W & BARTON/RICE/STAFFORD & 3,328 \\
\hline TRAPP & $300,087,115$ & 726 & 15S-14W & BARTON/RUSSELL & 3,252 \\
\hline EL DORADO & $299,365,153$ & 618 & $25 S-5 E$ & BUTLER & 2,550 \\
\hline BEMIS-SHUTTS & $248,694,147$ & 2,150 & 10S-16W & ELLIS/ROOKS & 2,967 \\
\hline HALL-GURNEY & $152,414,246$ & 1,107 & 14S-13W & BARTON/RUSSELL & 3,192 \\
\hline KRAFT-PRUSA & $130,826,618$ & 700 & 15S-10W & BARTON/ELLSWORTH/RUSSELL & 2,885 \\
\hline GORHAM & $94,783,868$ & 369 & 14S-15W & RUSSELL & 3,289 \\
\hline GENESEO-EDWARDS & $85,900,491$ & 190 & 18S-8W & ELLSWORTH/RICE & 3,278 \\
\hline FAIRPORT & $58,735,912$ & 388 & 12S-15W & ELLIS/RUSSELL & 3,350 \\
\hline BLOOMER & $55,787,569$ & 244 & 17S-10W & BARTON/ELLSWORTH/RICE & 3,200 \\
\hline STOLTENBERG & $52,996,954$ & 470 & 15S-19W & BARTON/ELLSWORTH & 3,333 \\
\hline RAY & $48,122,148$ & 159 & $5 S-20 W$ & GRAHAM, NORTON, PHILLIPS, ROOKS & 3,540 \\
\hline AUGUSTA & $47,773,725$ & 111 & 28S-4E & BUTLER & 2,600 \\
\hline MOREL & $46,765,270$ & 444 & 9S-21W & GRAHAM & 3,718 \\
\hline MARCOTTE & $41,659,245$ & 221 & 9S-19W & ROOKS & 3,752 \\
\hline VOSHELL & $36,066,429$ & 22 & $20 S-3 W$ & MCPHERSON & 3,400 \\
\hline IUKA-CARMI & $34,128,807$ & 226 & 27S-13W & PRATT & 4,354 \\
\hline COOPER & $25,486,646$ & 112 & 9S-20W & GRAHAM/ROOKS & 3,216 \\
\hline RUSSELL & $23,243,643$ & 53 & $13 S-14 \mathrm{~W}$ & RUSSELL & 3,280 \\
\hline GATES & $21,519,184$ & 125 & 21S-12W & STAFFORD & 3,679 \\
\hline TRICO & $20,959,428$ & 144 & 10S-20W & ELLIS/GRAHAM/ROOKS/TREGO & 3,651 \\
\hline RICHARDSON & $19,843,416$ & 75 & 22S-11W & STAFFORD & 3,537 \\
\hline OXFORD & $18,196,474$ & 26 & $32 \mathrm{~S}-2 \mathrm{E}$ & SUMNER & 2,890 \\
\hline BARRY & $17,812,734$ & 132 & 8S-19W & ROOKS & 3,430 \\
\hline MUELLER & $15,950,997$ & 105 & $21 \mathrm{~S}-12 \mathrm{~W}$ & STAFFORD & 3,594 \\
\hline OTIS-ALBERT & $15,278,960$ & 22 & 18S-16W & BARTON & 3,703 \\
\hline OGALLAH & $14,805,787$ & 37 & $12 \mathrm{~S}-21 \mathrm{~W}$ & TREGO & 3,961 \\
\hline GREENWICH & $14,165,749$ & 20 & $26 S-2 E$ & SEDGWICK & 3,321 \\
\hline BOYD & $14,055,036$ & 54 & 17S-13W & BARTON & 3,438 \\
\hline MAX & $13,344,772$ & 63 & 21S-11W & STAFFORD & 3,570 \\
\hline LORRAINE & $12,666,332$ & 26 & 17S-9W & ELLSWORTH & 3,200 \\
\hline TOBIAS & $12,521,480$ & & $20 S-9 W$ & RICE & 3,218 \\
\hline SOLOMON & $12,083,711$ & 86 & 11S-19W & ELLIS & 3,629 \\
\hline IRVIN & $11,812,943$ & 76 & $13 S-19 W$ & ELLIS & 3,860 \\
\hline NORTON & $11,692,977$ & 88 & 3S-23W & NORTON & 3,778 \\
\hline DOPITA & $11,321,826$ & 131 & $8 S-17 W$ & ROOKS & 3,409 \\
\hline HITTLE & $10,542,917$ & 240 & $31 S-4 E$ & COWLEY & 3,280 \\
\hline NORTHAMPTON & $10,113,608$ & 51 & 9S-20W & ROOKS & 3,803 \\
\hline DRACH & $10,016,115$ & 23 & $22 S-13 W$ & STAFFORD & 3,690 \\
\hline TOTAL & $2,379,114,304$ & 10,710 & & $\begin{array}{l}\text { Note: Many fields produce from multiple } \\
\text { horizons and not all production is Arbuckle }\end{array}$ & \\
\hline
\end{tabular}

interpretation that many low pressures reflect actual reservoir conditions and poor connection to the underlying aquifer, which is a significant departure from the commonly accepted paradigm of the presence of a strong bottom-water drive.

The variability in connection of upper Arbuckle strata to the underlying aquifer likely is due to a combination of structural, stratigraphic, karst, and other diagenetic controls. Detailed integrative studies can aid in understanding these controls on connectivity and provide predictive capabilities. An example is provided by Cansler and Carr (2001). They studied details of karst geomorphology of the upper Arbuckle surface at various scales, over the southern extent of the CKU (Barton, Ellsworth, Rice, and Stafford counties). In that study, the correspondence of sub-Pennsylvanian Arbuckle topography with Precambrian basement structural features was evaluated by superimposing structure contours of the top of the Precambrian surface, and interpreted lineaments from gravity and magnetic maps on the structure-contour map on the top of the Arbuckle (fig. 18). This analysis indicated that, although the sub-Pennsylvanian surface does not perfectly mimic the basement structure, when recognized, basement structure has a significant influence on alignment of karst and drainage features on the Arbuckle erosion surface. 


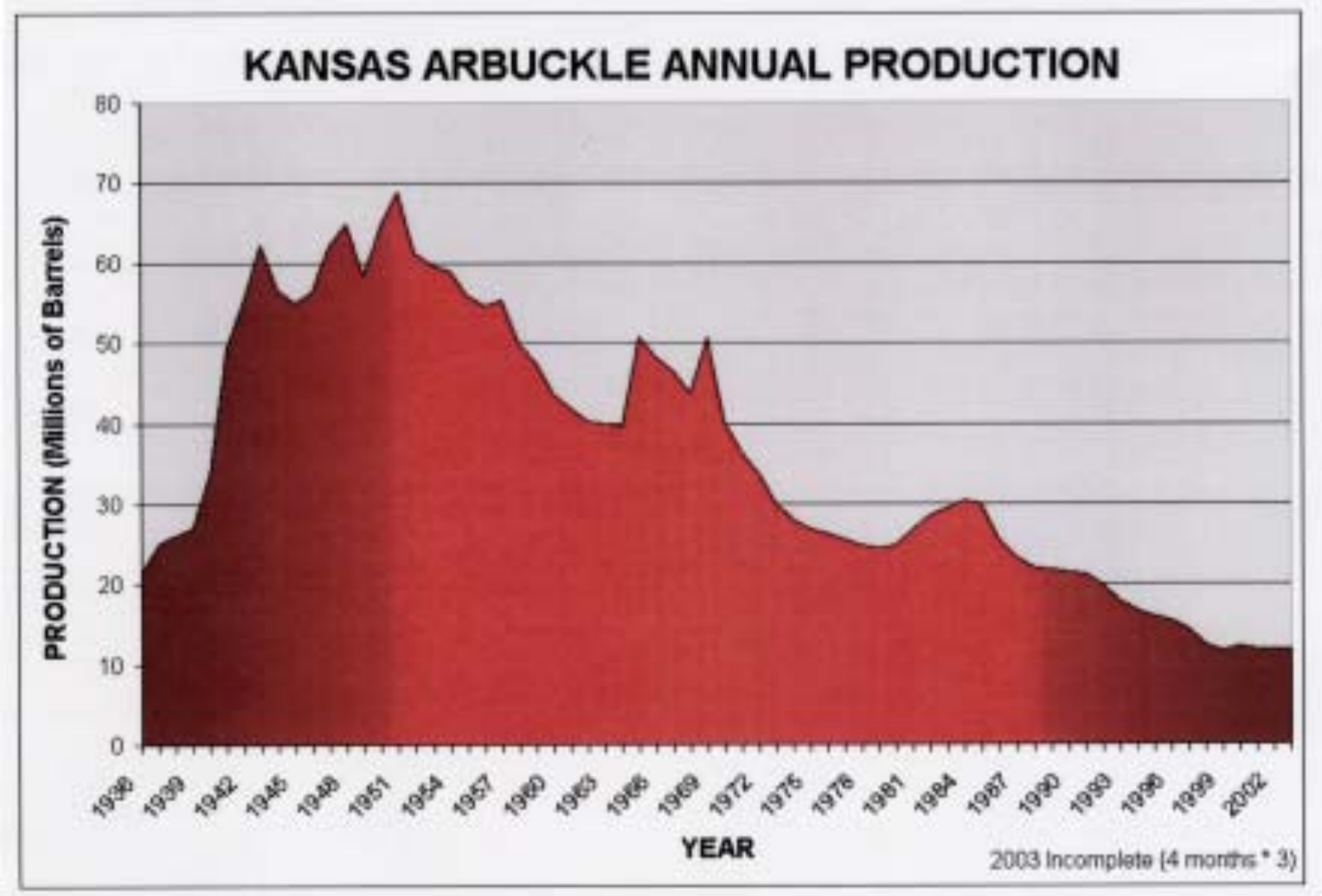

FIGURE 27. Annual production from Kansas Arbuckle reservoirs. Peak annual production was in 1951 (68,807,787 barrels) and has declined to an estimated 12 million barrels per year. Production prior to 1936 is not available in annual increments and is not shown.

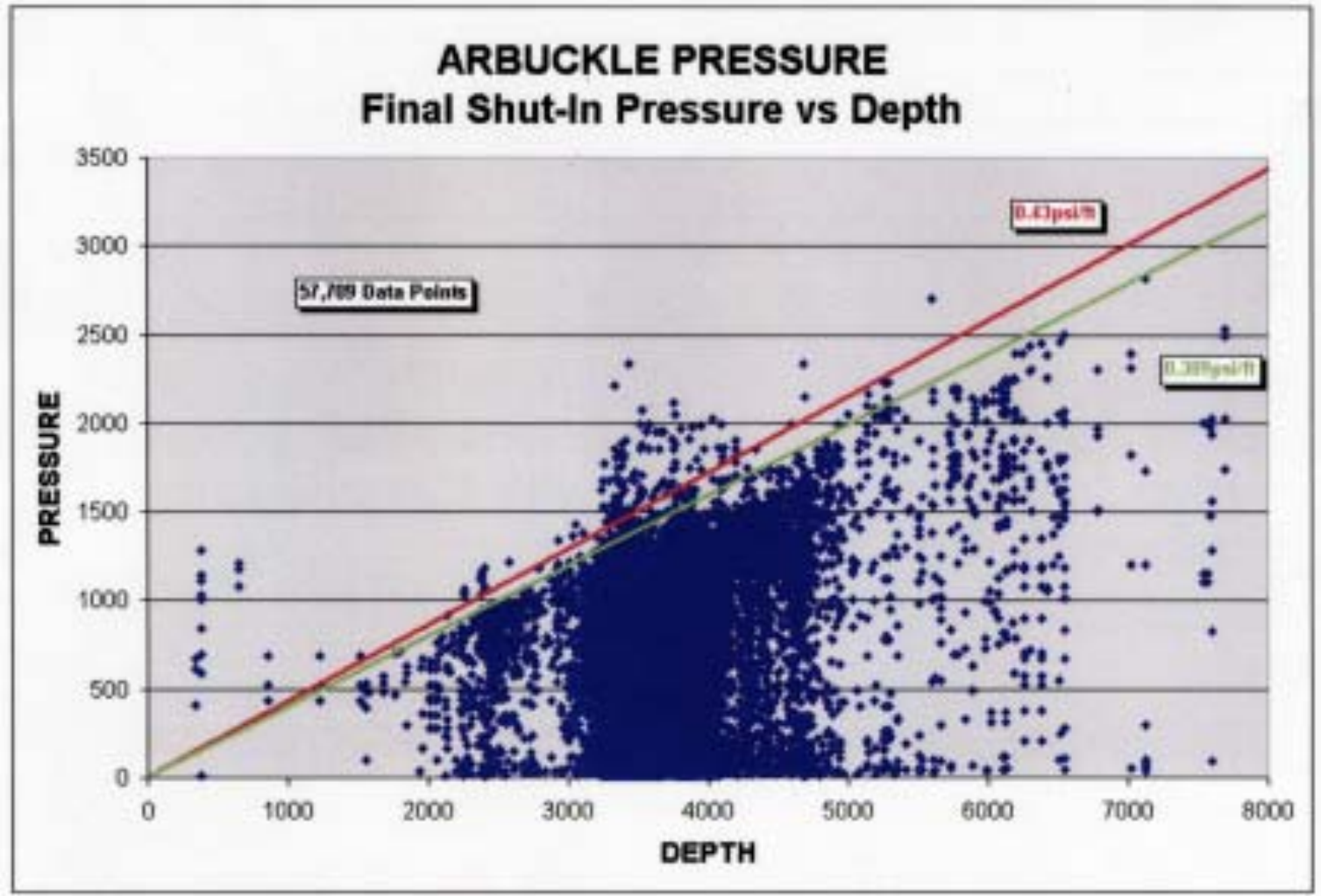

FIGURE 28. Final shut-in pressures for thousands of Arbuckle wells in Kansas. The pressures exhibit a wide distribution with a significant number exhibiting pressures less than half the regional hydrostatic pressure. 
Cansler and Carr (2001) recognized differences in oil productivity and drill stem test data from relatively recent (1960-present) infill wells between cockpit terrains and sapped plateau regions (figs. 29, 30). Relatively small, irregularly shaped fields that occur in mature cockpit landscapes experience relatively low cumulative production per well (typically 50,000-100,000 BO), whereas fields that occur on ground-water-sapped plateaus show significantly higher per well cumulative hydrocarbon recovery (200,000-300,000 BO). In general, infill wells located in areas dominated by cockpit karst experienced relatively high final shut-in pressures $(1,000-$ 1,200 psi) and infill wells located on sapped plateaus were characterized by significantly lower final shut-in pressures (250-750 psi). These differences in karst morphology, production, and pressures likely reflect differences in structural setting, relative contributions of through-going vertical fractures (impacting connectivity to the underlying aquifer), and stratigraphic elements, including types of facies.

Although some studies have utilized two-dimensional (2D) seismic data for study of the Arbuckle (e.g. Carr et al., 1994; Carr et al., 1995), detailed study of Arbuckle three-dimensional (3D) seismic data that exist in the private sector could provide valuable data and information on Arbuckle characteristics, including structural and stratigraphic elements.

Some recent efforts (e.g. Byrnes et al., 1999) have explored upscaling and integrating plug to well-scale petrophysics with detailed sedimentology to quantify the relative role of fracture, vug, and matrix properties in Arbuckle reservoirs. This integrated approach has implications for 1) understanding correlations between lithofacies and petrophysical properties; 2) developing a model to understand how core and DST permeabilities relate in laterally extensive cyclic carbonate strata (such as the Arbuckle); 3) developing a quantitative model for upscaling core permeability in laterally extensive cyclic carbonate strata; 4) providing insight on the potential for deeper Arbuckle traps; 5) information for determining when alternate production or IOR strategies, such as polymer modification or horizontal drilling may be warranted; and 6) developing an integrative approach to understanding geologic, core, log, and DST data.

Whereas good examples of wells where full integration can be performed are limited, initial results of integrated petrophysical studies of Arbuckle strata indicate that well production, particularly in sapped plateau-terrain reservoirs, can be explained by matrixscale permeability (plug to full-diameter core) and variations in permeability between lithofacies. Although the open-hole productive interval in a well consists of interbedded reservoir and non-reservoir intervals, total flow represents the cumulative flow that would be predicted by the permeability-height $(\mathrm{kh})$ of the total interval and primarily the permeability of the thin reservoir beds.
Reservoir-rock lithofacies, exhibiting porosities from 10 to $25 \%$ and permeabilities from 10 to 1,500 millidarcies, include laminated grainy algal boundstones and moldic packstone and grainstone. Non-reservoir rock lithofacies include mudstone, peloidal wackestone and packstone, muddy algal boundstone, and chert. In some cores, vugs locally enhance whole-core permeabilities up to 10 times. Where full-diameter core and drill-stem test permeabilities are not consistent, higher drill-stem permeabilities aid in identifying and quantifying fracturerelated flow.

In unfractured strata, differences between core and DST permeabilities may be explained by differences in flow-model assumptions and data-averaging methods. Geometric mean permeabilities, which mathematically represent random regional distribution of the permeabilities averaged, do not seem to accurately represent the layered flow system. Arithmetic mean permeabilities, which represent an average of a parallel flow system, are more consistent with the conceptual flow model for the Arbuckle system and provide better correlation with DST-calculated permeabilities. Modeled permeabilities based on upscaled core and log data indicate that small-scale laterally persistent stratal packages exert significant control on flow properties of the entire Arbuckle section. Integration of lithologic, stratigraphic, and petrophysical data at the plug, wholecore, and drill-stem test scales allows separation of the relative contributions of fractures, vugs, and matrix properties to reservoir flow.

Work is still on-going for testing the upscaling and modeling concepts and methodology. Arithmetic averaging of permeabilities and the use of the permeability-porosity trend has provided a significantly better correlation between DST and smaller-scale permeabilities.

The various aspects of the recent and ongoing research on Arbuckle strata in Kansas are providing insight on Arbuckle reservoir character and directions for future research to improve the emerging picture of Arbuckle reservoir types. Arbuckle strata consist of complex stacks of reservoir and non-reservoir lithologies at various frequency and thickness scales. Knowing this, the Arbuckle in Kansas can be viewed as having three endmember reservoir architectures, representing fracture-, karst-, and matrix-dominated architectural systems, with numerous possible variations between these end-member architectures (Franseen et al., 2003; fig. 31). Notably, in all three architectures, lithofacies and stratal packaging of reservoir and non-reservoir strata exert a control on reservoir architecture, despite other processes that affect the rocks.

The first end-member type is dominated by fractures, possibly related to faults in structurally complex areas (fig. 31A). In this type of reservoir scenario, lithofacies control porosity and permeability within individual layers (beds), but fractures dominate overall permeability. 


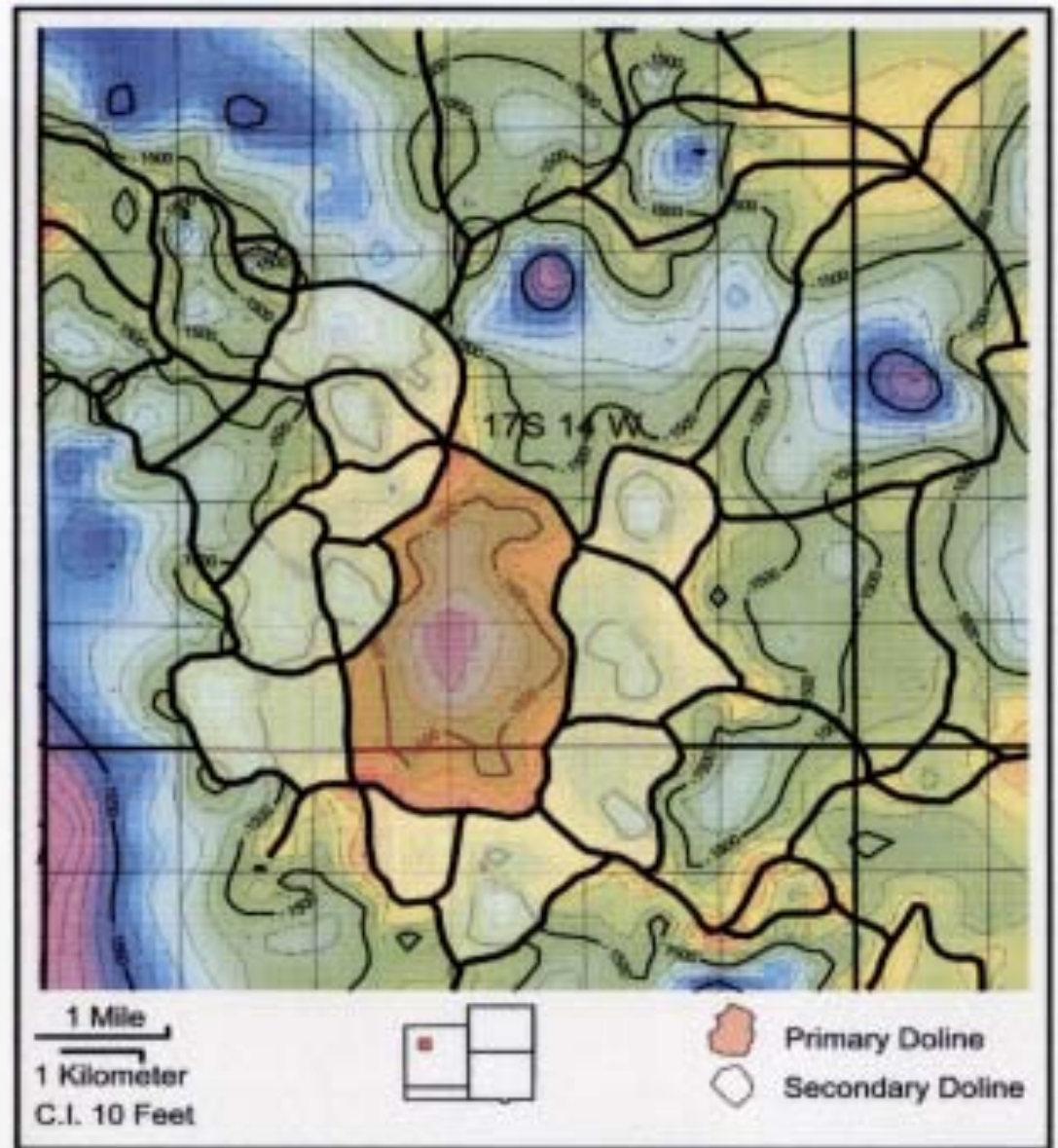

A

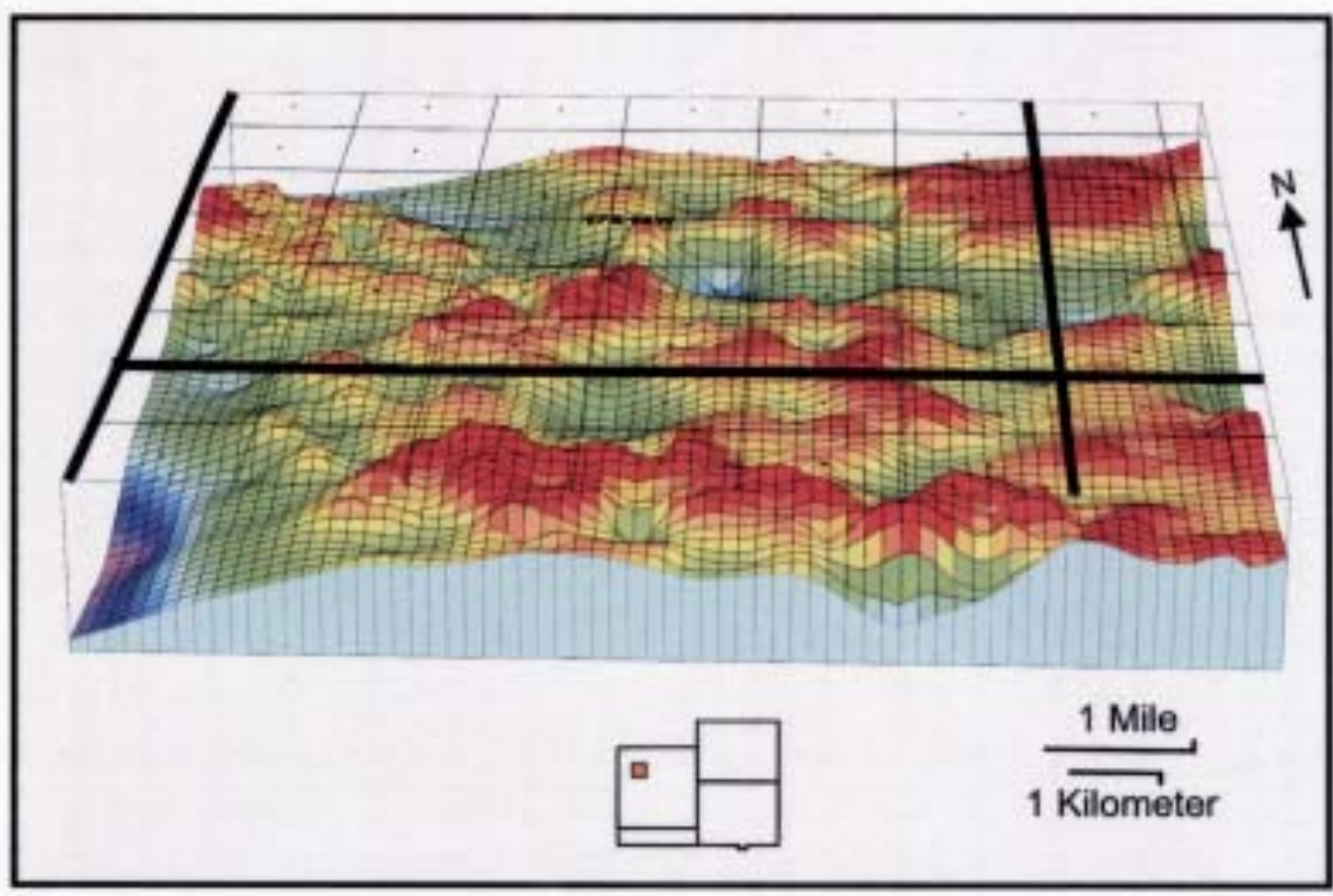

B

FIGURE 29. Map (A) and block diagram (B) illustrating characteristic features of cockpit (polygonal) karst terrain. Cockpit karst landscapes are visually dominated by the residual hills that occur between a system of closed depressions, and these topographic divides can be polygonal in shape. Vertical exaggeration on block diagram is $10 x$. 


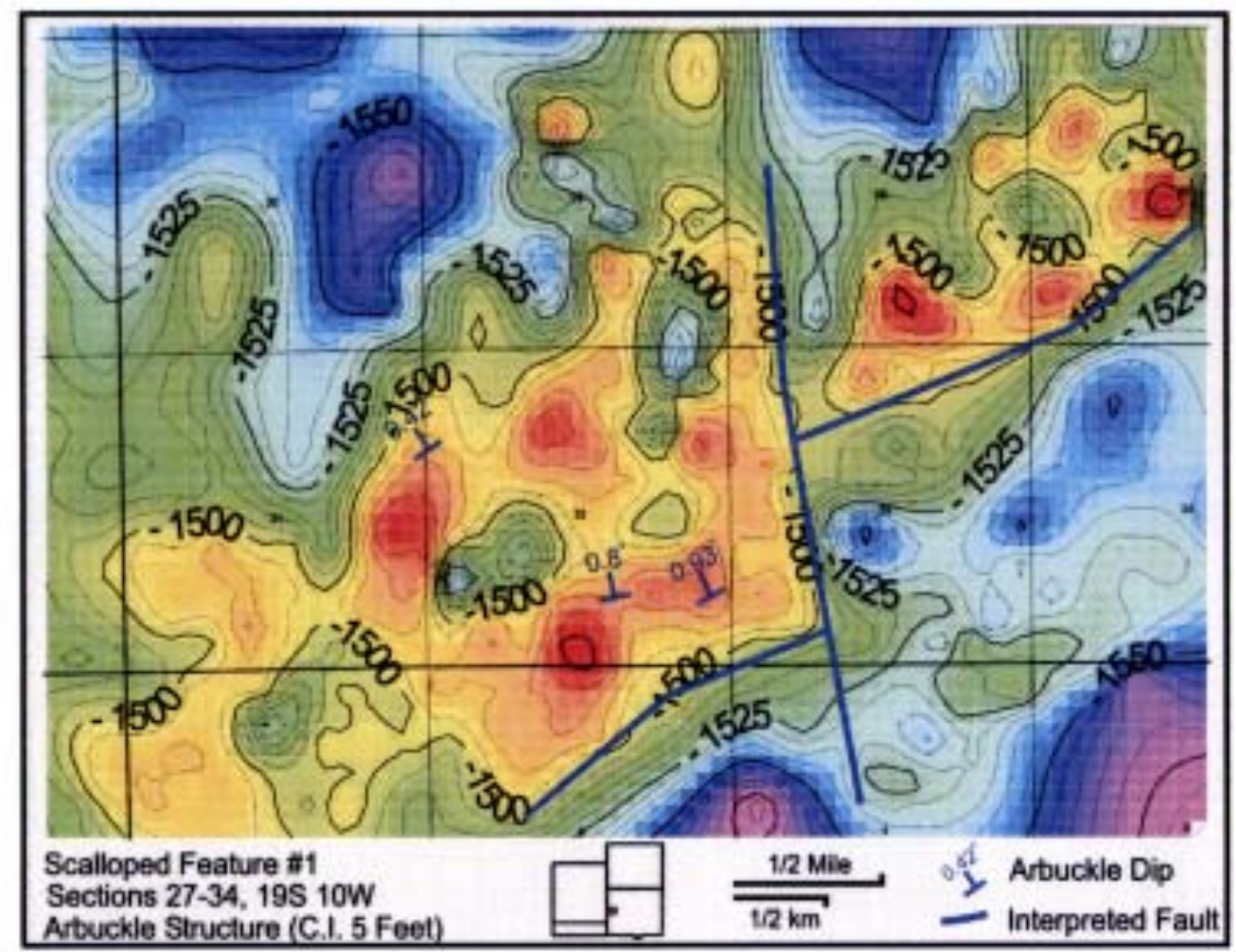

A

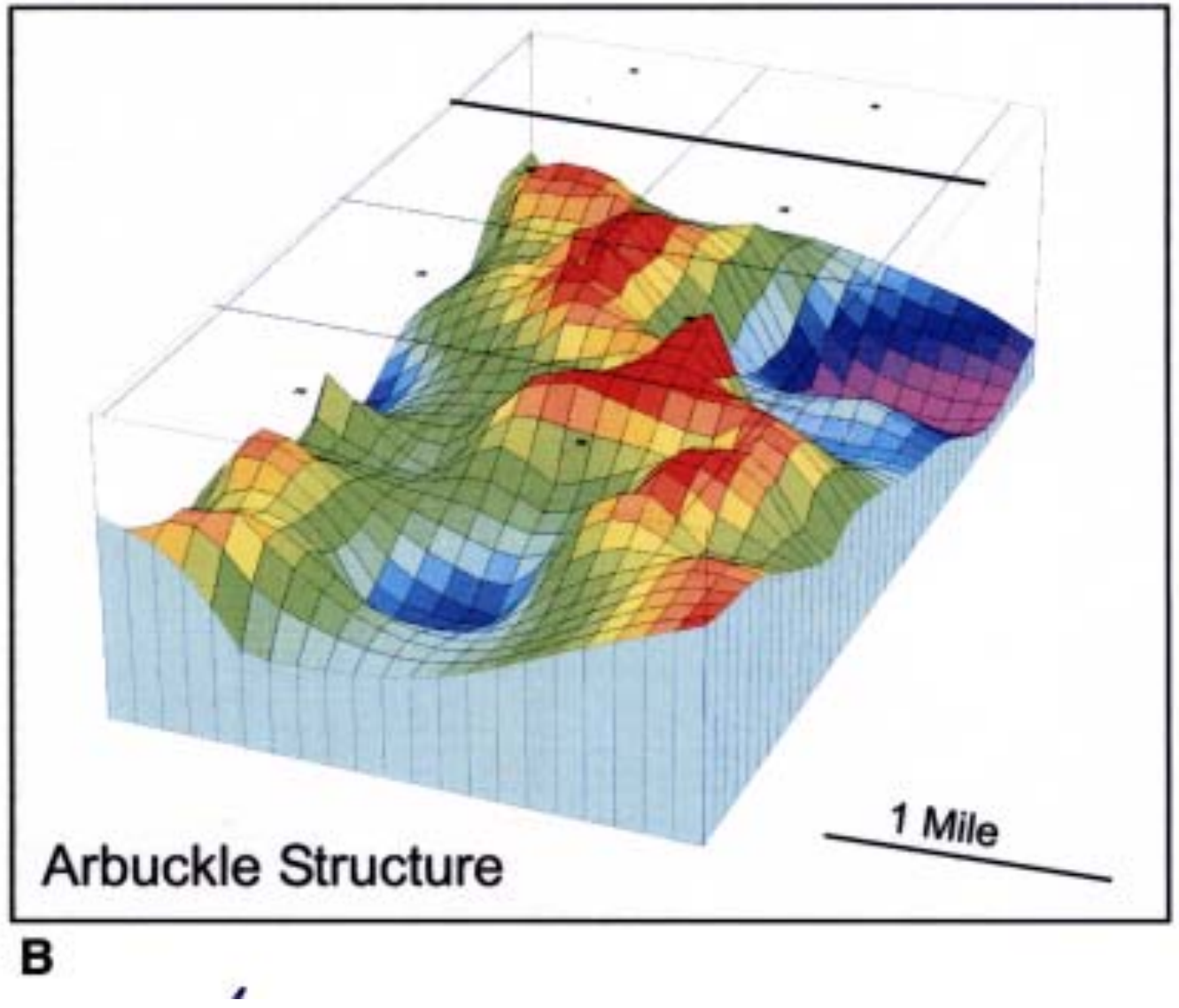

FIGURE 30. Map (A) and block diagram (B) illustrating characteristic features of sapped plateaus. The sapping processes produced scallops with theater-headed valley terminations on the northwest sides. Vertical exaggeration on block diagram is $10 \mathrm{x}$. 
The second end-member type of reservoir is the classic conceptual reservoir model for Arbuckle strata in Kansas. In this scenario processes associated with karst overprint lithofacies and fractures, resulting in complex porosity and permeability (fig. 31B). However, karst overprinting can vary laterally from being extensive to insignificant. Also, even where extensively developed, karst processes can both enhance or destroy reservoir properties. For example, open fractures, caves, and vugs in reservoir facies near the unconformity may enhance permeability. However, open fractures and vugs in nonreservoir facies are likely to be insignificant in enhancing overall reservoir character. This emphasizes the importance of understanding which lithologies intersect the unconformity. Additionally, infilling of fractures and vugs with karst sediment and cement associated with karst can completely destroy reservoir properties, even in favorable reservoir facies.

The third end-member type of reservoir shows relatively little fracturing and karst overprinting (fig. 31C). In this reservoir type, lithofacies control porosity and permeability, and laterally persistent stratal packages may exert significant control on flow properties. These types of reservoirs may be significant, especially where karst overprinting is not extensive, in areas away from faults, in areas off structural highs, and stratigraphically deeper within the Arbuckle.

As in the past, the ongoing and future research and an increased understanding of Arbuckle Group strata in Kansas will be closely tied into petroleum industry practices, trends, needs, and economic factors. Improved reservoir characterization and IOR efforts could potentially lead to recovery of hundreds of millions of barrels of oil from Arbuckle reservoirs in Kansas.

\section{ACKNOWLEDGMENTS}

Research included in this paper has been partially supported by two research grants from the University of Kansas Energy Research Center. Appreciation is extended to Rex Buchanan for reviewing an early version and to reviewers John E. Repetski and Paul J. Ramondetta who provided useful constructive comments. Marla AdkinsHeljeson is thanked for editorial assistance, and Jennifer Sims is thanked for graphics art support.

\section{References}

Adler, F. J., 1971, Future petroleum provinces of the midcontinent, region 7; in, Future Petroleum Provinces of the United States-Their Geology and Potential: American Association of Petroleum Geologists, Memoir 15, p. $985-$ 1,120 .

Aurin, F. L., Clark, G. C., and Trager, E. A., 1921, Notes on the subsurface pre-Pennsylvanian stratigraphy of the northern midcontinent oil fFields: American Association of Petroleum Geologists, Bulletin, v. 5, p. 117-153.
Baars, D. L., and Watney, W. L., 1991, Paleotectonic control on reservoir facies; in, Sedimentary Modeling-Computer Simulations and Methods for Improved Parameter Definition, E. K. Franseen, W. L. Watney, C. G. St. C. Kendall, and W. Ross, eds.: Kansas Geological Survey, Bulletin 233, p. 253-262.

Baars, D. L, and Maples, C. G., eds.,1998, Lexicon of geologic names of Kansas (through 1995): Kansas Geological Survey, Bulletin 231, 271 p.

Bartram, J. G., Imbt, W. C., and Shea, E. F., 1950, Oil and gas in Arbuckle and Ellenburger formations, midcontinent region: American Association of Petroleum Geologists, Bulletin, v. 34, no. 4, p. 682-700.

Barwick, J. S., 1928, The Salina basin of north-central Kansas: American Association of Petroleum Geologists, Bulletin, v. 12, p. 177-199.

Berendsen, P., and Blair, K., 1992, Midcontinent Rift System, Precambrian subcrop: Kansas Geological Survey, Open-file Report 92-41, map.

Blakey, Ron, 2004, Global plate tectonics and paleogeography: Northern Arizona University, web site http:// jan.ucc.nau.edu/ rcb7/ (accessed September 2004)

Bliefnick, D. M., 1992, Karst-related diagenesis and reservoir development in the Arbuckle Group, Paschall \#2 core, Wilburton field, Oklahoma; in, Permian Basin Section: Society of Economic Paleontologists and Mineralogists, Publication No. 92-33, p.137-152.

Byrnes, A. P., Franseen, E. K., and Steinhauff, D. M., 1999, Integrating plug to well-scale petrophysics with detailed sedimentology to quantify fracture, vug, and matrix properties in carbonate reservoirs-An example from the Arbuckle Group, Kansas: Kansas Geological Survey, Open-file Report 99-47.

Cansler, J. R. and Carr. T. R., 2001, Paleogeomorphology of the sub-Pennsylvanian unconformity of the Arbuckle Group (Cambrian-Lower Ordovician): Kansas Geological Survey, Open-file Report 2001-55.

Carr, T. R., Anderson, N. L., and Franseen, E. K., 1994, Paleogeomorphology of the upper Arbuckle karst surfaceImplications for reservoir and trap development in Kansas (abs.): American Association of Petroleum Geologists, Annual Convention Official Program, v. 3, p. 117.

Carr, T. R., Hopkins, J., Anderson, N. L., and Hedke, D. E., 1995, Case history of Hampton field (Arbuckle Group), Rush County, Kansas; in, Geophysical Atlas of Kansas, N. L. Anderson, D. Hedke, and others, eds.: Kansas Geological Survey, Bulletin 237, p. 43-46.

Chenoweth, P. A., 1968, Early Paleozoic (Arbuckle) overlap, southern midcontinent, United States: American Association of Petroleum Geologists, Bulletin, v. 52, p. $1,670-1,688$.

Cole, V. B., 1962, Configuration of the Precambrian basement rocks in Kansas: Kansas Geological Survey, Oil and Gas Investigations 26, map.

Cole, V. B., 1975, Subsurface Ordovician-Cambrian rocks in Kansas: Kansas Geological Survey, Subsurface Geology Series 2, $18 \mathrm{p}$.

Conley, C. D., 1980, Petrology of Arbuckle Group, central Kansas (abs.): American Association of Petroleum Geologists, Bulletin, v. 64, no. 6, p. 960.

Dalal, V. P., 1987, Characterization of the Arbuckle reservoir (Upper Cambrian to Lower Ordovician) of the Lyons underground gas storage field, Rice County, Kansas: M.S. 


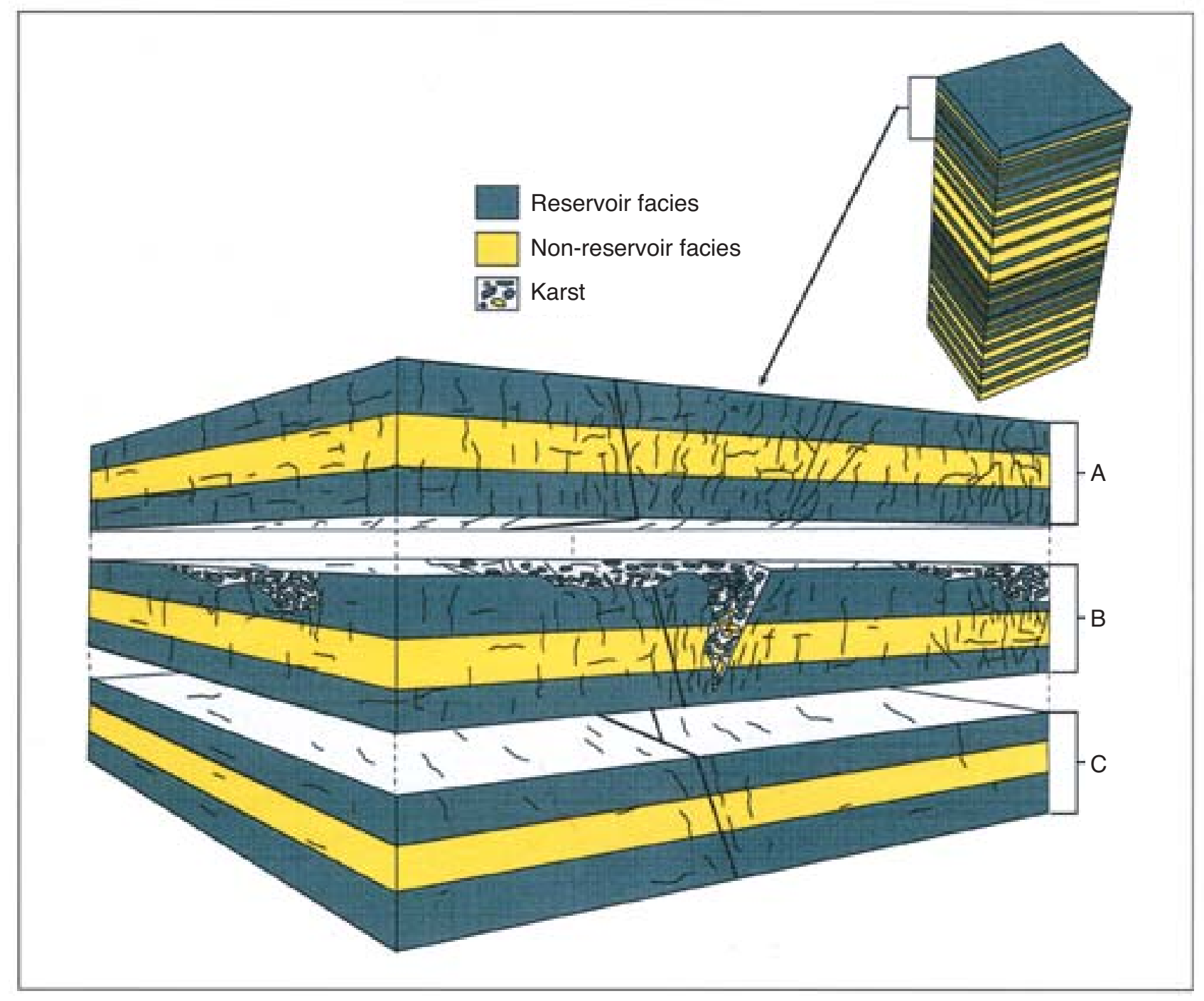

FIGURE 31. End-member Arbuckle reservoir types. A) Abundant fracturing of strata. Lithofacies control porosity and permeability within individual layers (beds), but fractures dominate overall permeability. B) Karst overprinting on lithofacies and fractures, resulting in complex porosity and permeability. Karst overprinting can vary laterally from insignificant to extensive. Even where extensively developed, karst processes can both enhance and destroy reservoir properties. C) Lithofacies control porosity and permeability, and laterally persistent stratal packages may exert significant control on flow properties.

thesis, Department of Geology, Wichita State University, $129 \mathrm{p}$.

Denison, R. E., 1966, Basement rocks in adjoining parts of Oklahoma, Kansas, Missouri, and Arkansas: Kansas Geological Survey, Open-file Report 66-1, 292 p.

Derby, J. R., Bauer, J. A., Miller, M. A., Creath, W. B., Repetski, J. R., Dresbach, R. I., Ethington, R. L., Loch, J. D., Stitt, J. H., Sweet, W. C., McHargue, T. R., Taylor, J. F., Miller, J. F., and Williams, M, 1991, Biostratigraphy of the Timbered Hills, Arbuckle, and Simpson Groups, Cambrian and Ordovician, Oklahoma-A review of correlation tools and techniques available to the explorationist; in, Late Cambrian-Ordovician Geology of the Southern
Midcontinent,, K. S. Johnson, ed.: Oklahoma Geological Survey, Circular 92, p. 15-41.

Derby, J. R., Hinch, H. H., and Repetski, J. R., 1991, Lithology, stratigraphy, and age of the Arbuckle Group in the Amoco SHADS No. 4, a continuous core from grassroots into basement, Rogers County, Oklahoma: Oklahoma Geological Survey, Special Publication 91-3, p. 69-82.

Edson, F. C., 1929, Pre-Mississippian sediments in central Kansas: American Association of Petroleum Geologists, Bulletin, v. 13, p. 441-458.

Fisher, J. H., and Barrett, M.W., 1985, Exploration in Ordovician of Central Michigan basin: American Association of Petroleum Geologists, Bulletin, v. 69, p. 2,065-2,076. 
Franseen, E. K., 1994, Facies and porosity relationships of Arbuckle strata-Initial observations from two cores, Rice and Rush counties, Kansas: Kansas Geological Survey, Open-file Report 94-53, 34 p.

Franseen, E. K., 2000, A review of Arbuckle Group strata in Kansas from a sedimentologic perspective-Insights for future research from past and recent studies: The Compass, Journal of Earth Sciences Sigma Gamma Epsilon, v. 75, nos. 2 and 3, p. 68-89.

Franseen, E. K., Byrnes, A. P., Cansler, J. R., Steinhauff, D. M., Carr, T. R., and Dubois, M. K., 2003, Geologic controls on variable character of Arbuckle reservoirs in Kansas-An emerging picture: Kansas Geological Survey, Open-file Report 2003-59, 30 p.

Goldhammer, R. K., Lehmann, P. J., and Dunn, P. A., 1993, The origin of high-frequency platform carbonate cycles and third-order sequences (Lower Ordovician El Paso Group, West Texas)-Constraints from outcrop data and stratigraphic modeling: Journal of Sedimentary Petrology, v. 63 , no. 3 , p. $318-359$.

Gore, G. E., 1954, Cave sandstones in Cotter Dolomite, northeastern Oklahoma: Tulsa, Geological Society, Digest, v. 20, p. $144-179$.

Hammes, U., 1997, Electrical imaging catalog: Microresistivity images and core photos from fractured, karsted, and brecciated carbonate rocks: Bureau of Economic Geology, Geology Circular 97-2, 40 p.

Harris, L. D., 1973, Dolomitization model for Upper Cambrian and Lower Ordovician carbonate rocks in the eastern United States: U.S. Geological Survey, Journal of Research, v. 1, p. 63-78.

Jewett, J. M., 1951, Geologic structures in Kansas: Kansas Geological Survey, Bulletin 90, p. 105-172.

Jewett, J. M., 1954, Oil and gas in eastern Kansas: Kansas Geological Survey, Bulletin 104, 397 p.

Kerans, C., 1990, Depositional systems and karst geology of the Ellenburger Group (Lower Ordovician) subsurface West Texas: Bureau of Economic Geology, University of Texas, Report of Investigations 193, 63 p.

Kerans, C., 1988, Karst-controlled reservoir heterogeneity in Ellenburger Group carbonates of West Texas: American Association of Petroleum Geologists, Bulletin, v. 72, no. 10, p. 1,160-1,183.

Kerans, C., and Lucia, F. J., 1989, Recognition of second, third, and fourth/fifth order scales of cyclicity in the El Paso Group and their relation to genesis and architecture of Ellenburger reservoirs: SEPM (Society for Sedimentary Geology), Permian Basin Section, Publication 89-31, p. 105-110.

Keroher, R. P., 1940a, Pre-Carboniferous rocks; in, Oil and Gas in Linn County, Kansas, J. M. Jewett, ed.: Kansas Geological Survey, Bulletin 30, p. 12-14.

Keroher, R. P., 1940b, Pre-Mississippian rocks; in, Oil and Gas in Montgomery County, Kansas, G. E. Abernathy, ed.: Kansas Geological Survey, Bulletin 31, p. 10-13.

Keroher, R. P., and Kirby, J. J., 1948, Upper Cambrian and Lower Ordovician rocks in Kansas: Kansas Geological Survey, Bulletin 72, $140 \mathrm{p}$.

Koester, E. A., 1935, Geology of the Central Kansas uplift: American Association of Petroleum Geologists, Bulletin, v. 19, p. $1,405-1,426$.
Kruger, J. M., 1996, On-line gravity and magnetic maps of Kansas: Kansas Geological Survey, Open-file Report 9651.

Kupecz, J. A., 1992, Sequence boundary control on hydrocarbon reservoir development, Ellenburger Group, Texas: SEPM (Society for Sedimentary Geology), Permian Basin Section, Publication No. 92-33, p. 55-58.

Lee, W., 1943, The stratigraphy and structural development of the Forest City basin in Kansas: Kansas Geological Survey, Bulletin 51, 142 p.

Lee, W., 1956, Stratigraphy and structural development of the Salina basin area: Kansas Geological Survey, Bulletin 121, $167 \mathrm{p}$.

McClellan, H. W., 1930, Subsurface distribution of preMississippian rocks of Kansas and Oklahoma: American Association of Petroleum Geologists, Bulletin, v. 14, p. 1,535-1,556.

McCracken, E., 1955, Correlation of insoluble residue zones of upper Arbuckle of Missouri and southern Kansas: American Association of Petroleum Geologists, Bulletin, v. 39, p. 47-59.

McQueen, H. S., 1931, Insoluble residues as a guide in stratigraphic studies: Missouri Bureau of Geology and Mines, Biennial Report 1929-1930, p. 102-131.

Merriam, D. F., 1963, The geologic history of Kansas: Kansas Geological Survey, Bulletin 162, 317 p.

Merriam, D. F., and Atkinson, W. R., 1956, Simpson-filled sinkholes in eastern Kansas: Kansas Geological Survey, Bulletin 119, pt. 2, p. 61-80.

Merriam, D. F., and Smith, P., 1961, Preliminary regional structural contour map on top of Arbuckle rocks (Cambrian-Ordovician) in Kansas: Kansas Geological Survey, Oil and Gas Investigations 25.

Montanez, I. P., 1992, Controls of eustasy and associated diagenesis on reservoir heterogeneity in Lower Ordovician, upper Knox carbonates, Appalachians: SEPM (Society for Sedimentary Geology), Permian Basin Section, Publication 92-33, p. $165-181$

Moore, R. C., Frye, J. C., Jewett, J. M., Lee, W., and O'Connor, H. G, 1951, The Kansas rock column: Kansas Geological Survey, Bulletin 89, 132 p.

Mullins, C. A., and Ireland, W. C., 1967, Additional Arbuckle reserves developed below original completion depth in stratified reservoir: Society of Petroleum Engineers of AIME, Paper No. SPE 1963.

Newell, K. D., Watney, W. L., Cheng, S. W. L., and Brownrigg, R. L., 1987, Stratigraphic and spatial distribution of oil and gas production in Kansas: Kansas Geological Survey, Subsurface Geology Series 9, 86 p.

Newell, K. D., Watney, W. L., Steeples, D. W., Knapp, R. W., and Cheng, S. W. L., 1989, Suitability of high-resolution seismic method to identifying petroleum reservoirs in Kansas-A geological perspective; in, Geophysics in Kansas, D. W. Steeples, ed.: Kansas Geological Survey, Bulletin 226, p. 9-30.

Ockerman, J. W., 1935, Subsurface studies in northeastern Kansas: Kansas Geological Survey, Bulletin 20, 78 p.

Overstreet, R. B., Oboh-Ikuenobe, F. E., and Gregg, J. M., 2003, Sequence stratigraphy and depositional facies of Lower Ordovician cyclic carbonate rocks, southern Missouri, U.S.A.: Journal of Sedimentary Research, v. 73, p. 421-433. 
Ramondetta, P. J., 1990, El Dorado-An old field with potential: Oil and Gas Journal, March 26, p. 110-116.

Ross, R. J. Jr., 1976, Ordovician sedimentation in the western United States; in, The Ordovician System: Proceedings of a Palaeontologic Association Symposium, Birmingham, September 1974, M. G. Bassett, ed.: University of Wales Press and Natural Museum of Wales, Cardiff, p. 73-106.

Ross, C. A., and Ross, J. R., 1988, Late Paleozoic transgressiveregressive deposition; in, Sea Level Changes-An Integrated Approach, C. K. Wilgus, B. S. Hastings, C. G. Kendall, H. W. Posamentier, C. A. Ross, and J. C. Van Wagoner, eds: Society of Economic Paleontologists and Mineralogists (SEPM) Special Publication No. 42, p. 227247.

Schrader, F. C., 1908, Independence, Kansas: U.S. Geological Survey, Folio 159, p. 4.

Shelton, J., and Gerken, L., 1995, Recognizing sequence surfaces in midcontinent siliciclastic strata; in, Sequence Stratigraphy of the Midcontinent, N. J. Hyne, ed.: Tulsa Geological Society, Special Publication 4, p. 31-48.

Sloss, L. L., 1963, Sequences in the cratonic interior of North America: Geological Society of America, Bulletin, v. 74, p. 93-114.

Sloss, L. L., 1988, Tectonic evolution of the craton in Phanerozoic time; in, Sedimentary Cover-North American Craton-U.S., L. L. Sloss, ed.: The Geological Society of America, The Geology of North America Volume D-2, p. 25-51.

Steinhauff, M., Franseen, E. K., and Byrnes, A., 1998, Arbuckle reservoirs in central Kansas-Relative importance of depositional facies, early diagenesis and unconformity karst processes on reservoir properties: Kansas Geological Survey, Open-file Report 98-55.

Taff, J. A., 1902, Description of the Atoka quadrangle: U.S. Geological Survey, Folio 79, p. 1-8.

Twenhofel, W. H., 1927, Ordovician strata in deep wells of western central Kansas: American Association of Petroleum Geologists, Bulletin, v. 11, p. 49-53.

Ulrich, E. O., 1911, Revision of the Paleozoic System: Geological Society of America, Bulletin, v. 22, p. 281-680.

Walters, R. F., 1946, Buried Precambrian hills in northeastern Barton County, central Kansas: American Association of Petroleum Geologists, Bulletin, v. 30, p. 660-710.

Walters, R. F., 1958, Differential entrapment of oil and gas in Arbuckle dolomite of central Kansas: American Association of Petroleum Geologists, Bulletin, v. 42, p. 2,133-2,173.

Walters, R. F., 1991, Gorham oil field, Russell County, Kansas: Kansas Geological Survey, Bulletin 228, 112 p.

Watney, W. L., and Paul, S. E., 1983, Oil exploration and production in Kansas-Present activity and future potential: Oil \& Gas Journal, v. 81, no. 30, p. 193-198.

Wilson, J. L., Fritz, R. D., and Medlock, P. L., 1991, The Arbuckle Group-Relationship of core and outcrop analyses to cyclic stratigraphy and correlation; in, Arbuckle Core Workshop and Field Trip, K. S. Johnson, ed.: Oklahoma Geological Survey, Special Publication 91-3, p. 133-144.

Zeller, D. E., ed., 1968, The stratigraphic succession in Kansas: Kansas Geological Survey, Bulletin 189, 81 p. 